ANA MARIA DE BIAZZI DIAS DE OLIVEIRA

DINÂMICA DA RUA DE COMÉRCIO NA CIDADE DE SÃO PAULO

Dissertação apresentada à Escola Politécnica da Universidadede São Paulo para obtenção do título de Mestre em Engenharia

São Paulo 


\title{
DINÂMICA DA RUA DE COMÉRCIO NA CIDADE DE SÃO PAULO
}

\author{
Dissertação apresentada à Escola \\ Politécnica da Universidadede São Paulo \\ para obtenção do título de Mestre em \\ Engenharia
}

Área de Concentração:

Construção Civil e Urbana.

Orientador:

Professor Dr. Witold Zmitrowicz

São Paulo 


\section{RESUMO}

Este estudo dedica-se a levantar elementos que configurem a dinâmica da rua de comércio dentro de um contexto de transformações recentes da atividade comercial na cidade de São Paulo.

O método envolve primeiro, num âmbito geral, o estudo da dinâmica da rua de comércio sob três diferentes aspectos: pela evolução urbana, pelas transformações sócio-econômicas e pelos hábitos de compra do consumidor.

A síntese se apóia em pesquisas quantitativas para relacionar as principais ruas de comércio, categorias de produtos mais procurados e as razões pelas quais as pessoas freqüentam estas ruas de comércio.

Apresenta, em conclusão, os principais atributos de uma rua de comércio, através do levantamento do seu mix de lojas, ocupação e transformações.

Palavras-chave:

Rua, Comércio, Varejo, Hábitos de Compra. 


\section{ABSTRACT}

This study proposes to come up with elements which configurate the commerce street dynamic inside a recent transformation context of commercial activity in São Paulo city.

The method envolves the study of the street dynamic upon three different aspects: through the urban evolution, the socio-economic transformation and the consumer shopping habits.

The synthesis is supported on quantitative researches to relate the main commerce streets, products categories most required and the reason why people go to those commerce streets.

It presents the main attributes of a commerce street, through the survey of its mix, occupation and present transformation.

Key-words:

Street, commerce, retail, shopping habits 
meu marido Paulo Fernando, sempre presente, principalmente nos momentos de maior alegria. Pela sua fundamental participação: no início, meio e fim. 


\section{AGRADECIMENTOS}

Ao Prof. Dr. Witold Zmitrowicz por sua orientação, confiança e motivação na escolha do tema e dos caminhos trilhados ao longo da pesquisa.

A Fátima Domingues pela inestimável ajuda e carinho.

Ao meu mentor profissional, engenheiro Joaquim da Rocha Medeiros Jr. por ter me ensinado, instruído e principalmente me embuído de todos os conceitos e praticas da ética profissional.

Às Prof ${ }^{\text {as }}$. Dr ${ }^{\text {as }}$. Eliane Moneti e Gilda Collet Bruna, pela participação, valiosas contribuições, importantes sugestões e incentivos no Exame de Qualificação, imprescindíveis para continuidade e finalização deste trabalho.

Ao amigo Manoel Kherlakian, pelas estimulantes conversas que permitiram descobertas preciosas e maior conhecimento do comércio.

Agradeço à Toledo \& Associados, especialmente ao Fernando, pela grande colaboração e fornecimento de dados que permitiram desenvolvimento de parte este trabalho.

A Sra. Hilda Mecca pelo carinho, presteza na revisão de português do texto.

Ao amigo Luis Fernando Moura, vice presidente da área de Shopping Centers da Brascan, pelas valiosas informações.

A amiga Carminha Cecci pelos três meses em Londres que me fizeram ver um outro lado de planejamento e organização urbana.

Aos amigos Fulvio, Paulo Trivolli por colaborações especiais em diferentes fases da pesquisa.

A Cushman \& Wakwfied Senco em nome dos amigos Marcio e Luciana, pelo material disponibilizado para consulta.

A Urban Systems Brasil, em nome do Paulo, pelo incentivo no inicio da elaboração deste trabalho.

Ao amigo Eduardo Luis Thomas pelo auxílio à pesquisa de campo.

A todos os amigos da Acepel - Associação dos Comerciantes, Proprietário e Empreendedores da Lapa.

A Subprefeitura da Lapa em nome do Dr. Paulo Bressan (Subprefeito) e Roberto Nappo (chefe de Gabinete). 


\section{SUMÁRIO}

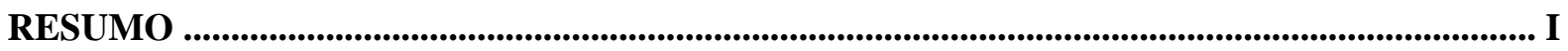

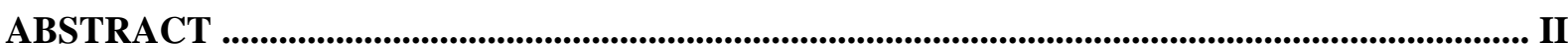

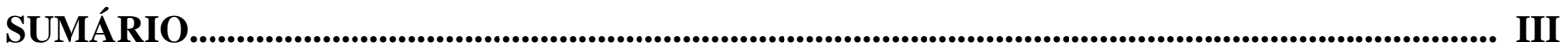

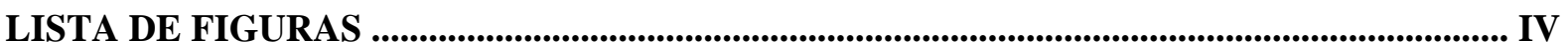

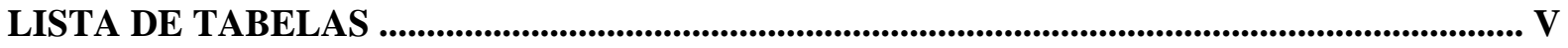

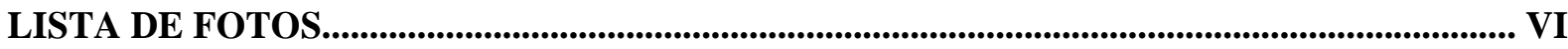

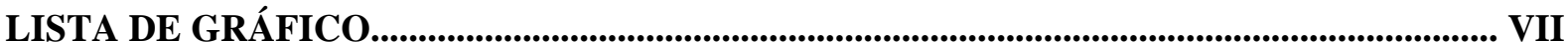

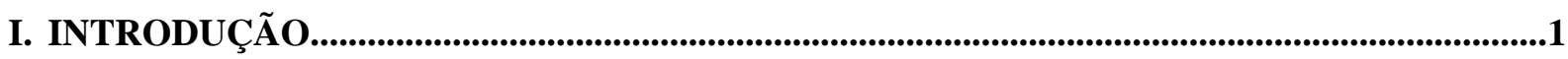

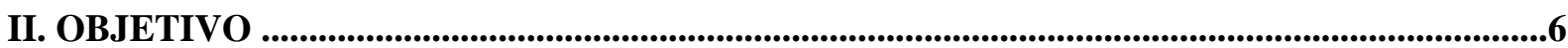

III. METODOLOGIA DA PESQUISA E ESTRUTURA DO TEXTO ........................................6

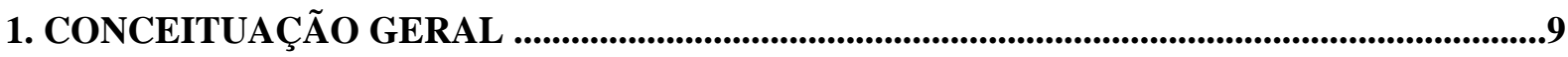

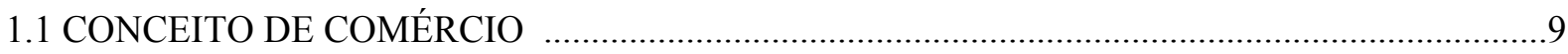

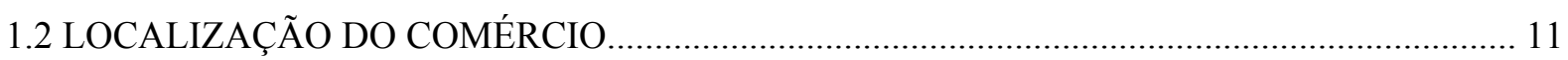

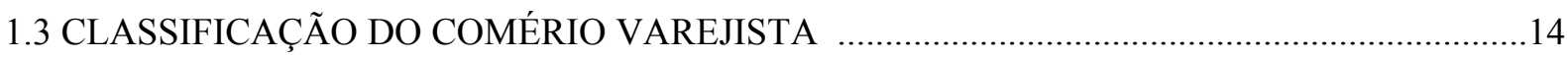

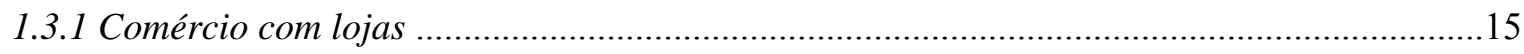

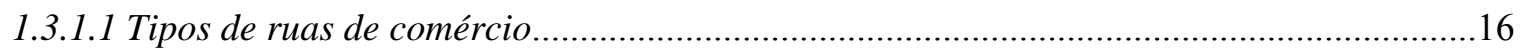

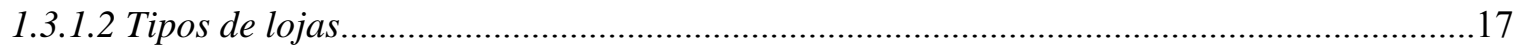

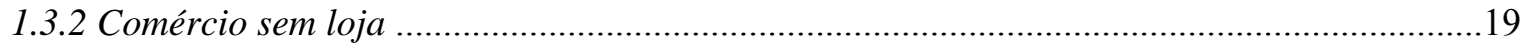

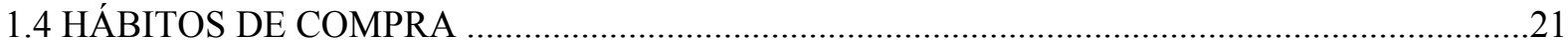

\section{TRANSFORMAÇÕES DO COMÉRCIO E EVOLUÇÃO URBANA NA CIDADE DE}

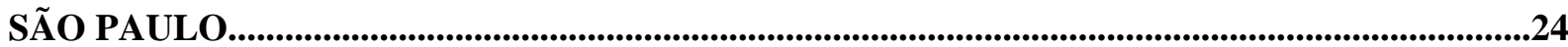

2.1 A FORMAÇÃO DO COMÉRCIO TRADICIONAL: PRIMEIRAS RUAS COMERCIAIS

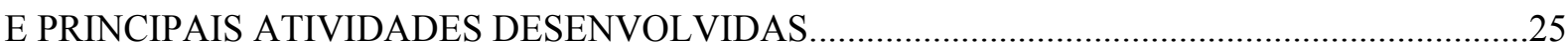

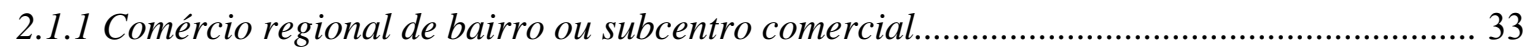

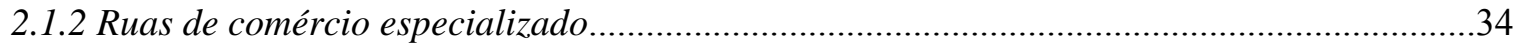

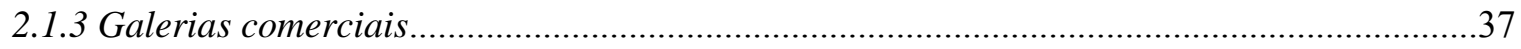


2.2 TRANSFORMAÇÕES NO ESPAÇO URBANO EM FUNÇÃO DE NOVOS FORMATOS

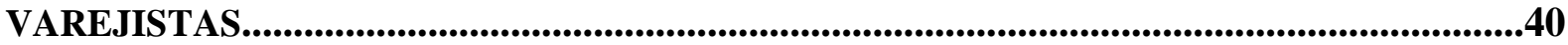

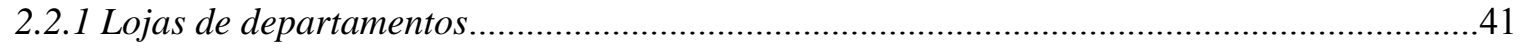

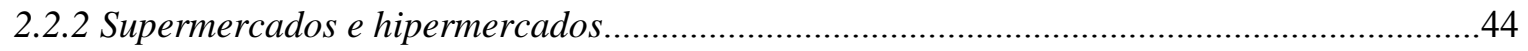

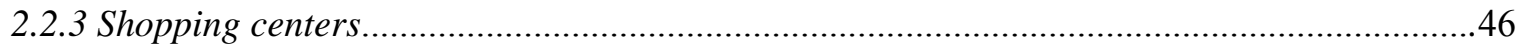

3. TRANSFORMAÇ!ÕES DEMOGRAFICAS, ECONOMICAS E SOCIAIS...............................56

3.1 COMÉRCIO INFORMAL TRANFORMA RUA DE COMÉRCIO EM COMÉRCIO DE RUA...59

4. HABITOS DE COMPRA E A RUA DE COMÉRCIO............................................................71

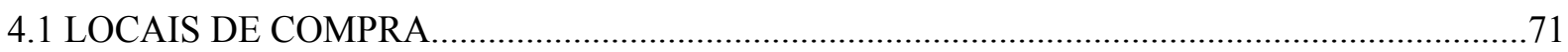

4.2 PRODUTOS PREFERENCIALMENTE COMPRSADOS EM LOJAS DE RUA, ALÉM

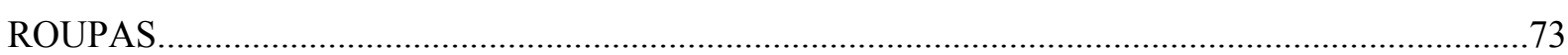

4.3 RUAS COMERCIAIS ONDE SE COMPRA REGULARMENTE.................................................74

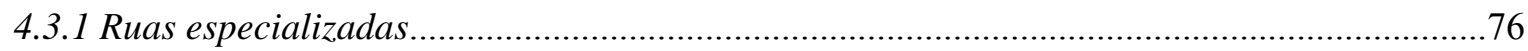

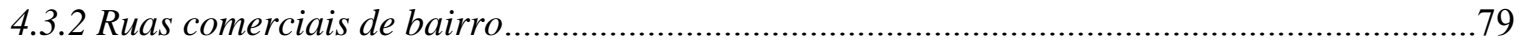

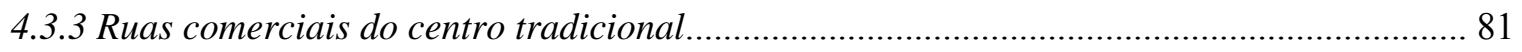

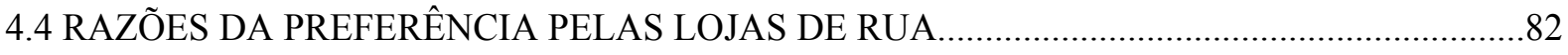

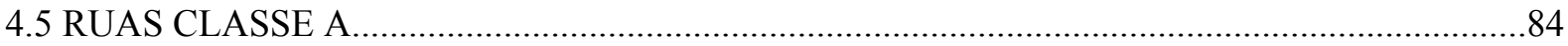

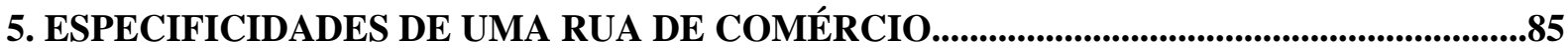

5.1 TRANSFORMAÇÕES RECENTES - REVITALIZAÇÃO DE RUAS COMERCIAIS.................85

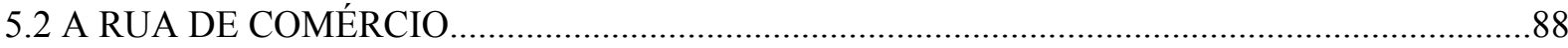

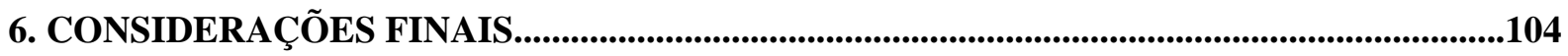

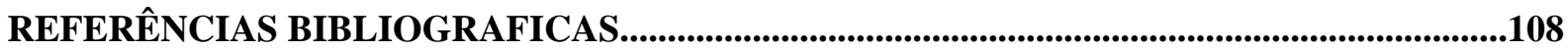




\section{LISTA DE FIGURAS}

Figura 2.1 Evolução da mancha urbana na cidade de São Paulo.............................................55

Figura 2.2 Transformação do comércio e crescimento da população.....................................55

Figura 3.1 Mapa com dispersão de lojas da Casas Bahia na cidade .....................................68

Figura 5.1 Mapa de localização, fluxo de transportes/ viários da rua Doze de Outubro........90

Figura 5.2 Mapa do mix de lojas da rua Doze de Outubro, distribuição por atividades.........95

Figura 5.3 Mapa de dispersão dos tipos de lojas existentes na rua Doze de Outubro ..........97

Figura 5.4 Mapa da dispersão das lojas de roupas e calçados na rua Doze de Outubro..........99

Figura 5.5 Mapa da dispersão das lojas, por segmento de produtos na rua Doze de Outubro

\section{LISTA DE TABELAS}

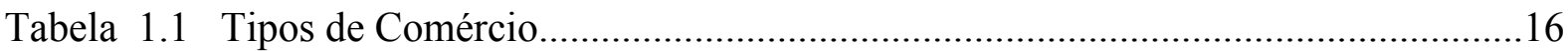

Tabela 2.1 Principais ruas especializadas na cidade de São Paulo........................................36

Tabela 3.1 Crescimento da população, do PIB e dos equipamentos domésticos...................56

Tabela 3.2 População ocupada por setor de atividade.........................................................58

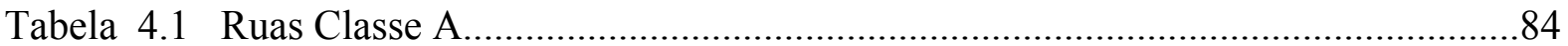

Tabela 5.1 Distribuição do mix das lojas na rua Doze de Outubro, segmentação por atividades

Tabela 5.2 Distribuição das lojas da rua Doze de Outubro por tipos de produtos 


\section{LISTA DE FOTOS}

Foto 2.1 - Rua XV de Novembro em 1913 _..........................................................................

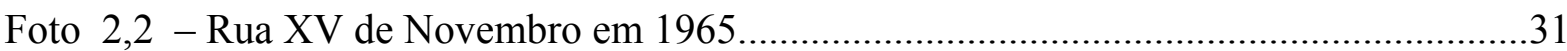

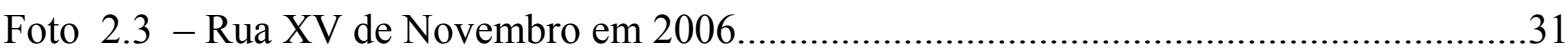

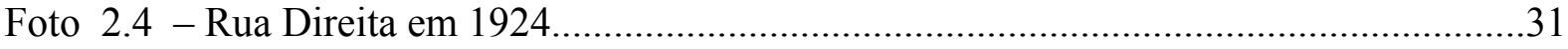

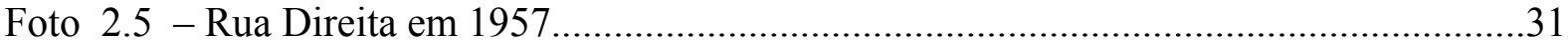

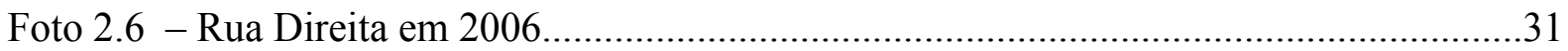

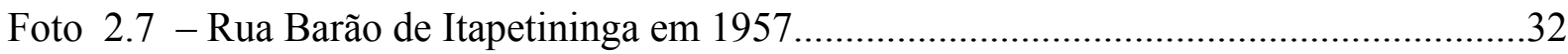

Foto 2.8 - Rua Barão de Itapetininga em 2006.....................................................................32

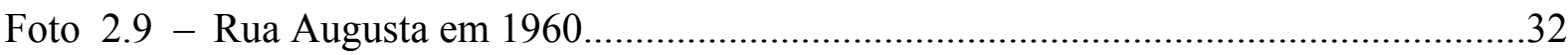

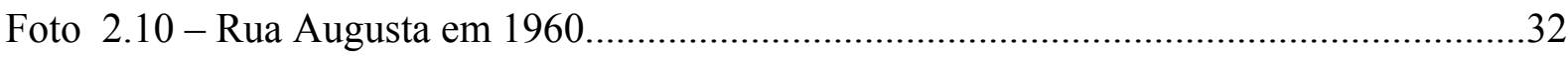

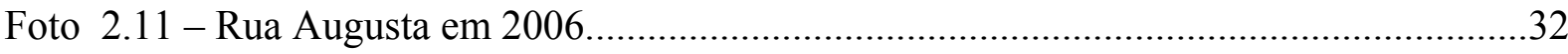

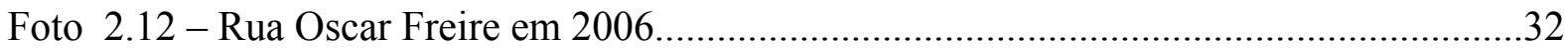

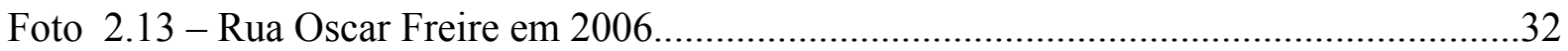

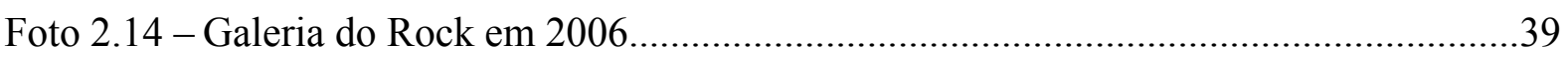

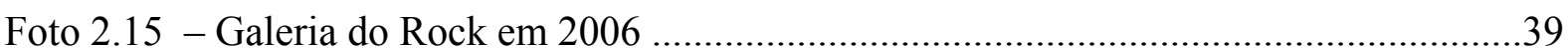

Foto 3.1 - Rua Vinte e Cinco de Março em 2005.....................................................................61

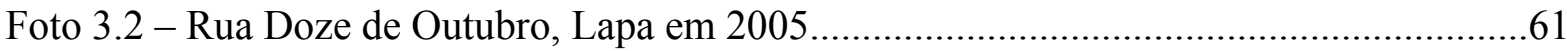

Foto 3.3 - Rua Doze de Outubro, Lapa em 2005................................................................62

Foto 3.4 - Rua Doze de Outubro, Lapa em 2005..............................................................62

Foto 3.5- Financiadora Itaií, Rua São Bento.......................................................................66

Foto 3.6- Financiadoras Losango, JRL, Finasa, Rua São Bento.............................................66

Foto 3.7-Financiadora Fininvest , Rua São Bento...............................................................66

Foto 3.8 - Loja Casas Bahia, avenida Itaberaba, Zona Norte...............................................67

Foto 3.9 - Avenida Itaberaba, Zona Norte, onde está instalada loja das Casas Bahia............67 
Foto 3.10 - Lojas Mappin, prédio na Praça Ramos, 1960........................................................69

Foto 3.11 - Casas Bahia, prédio da praça Ramos a partir de dez, 2004 ...........................................69

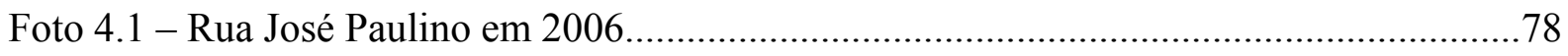

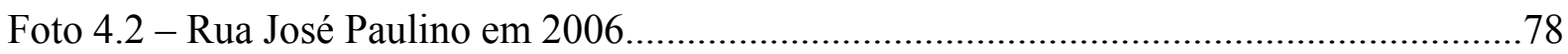

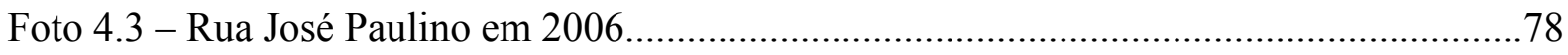

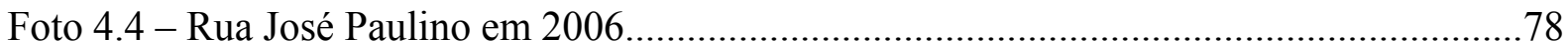

Foto 4.5 - Rua Prof. Cesare Lombroso em 2006................................................................... 78

Foto 4.6 - Vitrine de Loja Rua Prof. Cesare Lombroso......................................................... 78

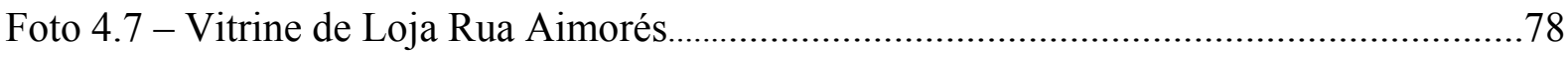

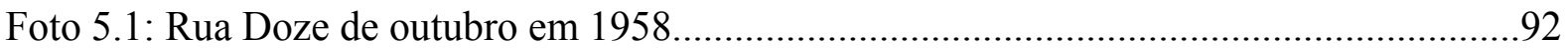

Foto 5.2: Rua Doze de outubro, concentração do comércio ambulante, 1977..........................92

Foto 5.3: Rua Doze de outubro ocupada pelo comércio ambulante......................................92

Foto 5.4: Ambulantes no leito da Rua Doze de outubro.........................................................99

Foto 5.5: Rua Doze de outubro, depois da retirada dos ambulantes do seu leito.....................92

Foto 5.6: Rua Doze de outubro depois da retirada dos ambulantes.......................................92 


\section{LISTA DE GRÁFICOS}

Gráfico 2.1 - Crescimento das vendas no varejo e nos shoppings do Brasil (1994 2002).... 49

Gráfico 3.1 - Crescimento da população, do PIB, automóveis e televisores.............................57

Gráfico 3.2 - Classificação sócia econômica classes A/B, C e D...........................................63

Gráfico 3.3 - Ascensão da Participação no consumo da Classe C...........................................64

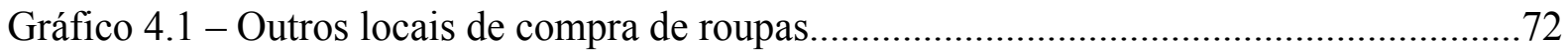

Gráfico 4.2 - Outros locais de compra de roupas, por classe social.....................................72

Gráfico 4.3 - Outros produtos preferencialmente comprados em lojas de rua........................73

Gráfico 4.4 - Outros produtos por classe sócio econômica..................................................74

Gráfico 4.5 - Ruas comerciais onde compram roupas regularmente....................................75

Gráfico 4.6 - Rua 25 de Março, por idade, classe sócio-econômica e regiões da cidade..........76

Gráfico 4.7 - Rua José Paulino, por idade, classe social e regiões da cidade .........................77

Gráfico 4.8 - Rua Maria Marcolina, por idade, classe social e regiões da cidade....................79

Gráfico 4.9 - Ruas comerciais de bairro, agrupadas por regiões da cidade...........................80

Gráfico 4.10 - Ruas comerciais de bairro, agrupadas por classificação sócio-

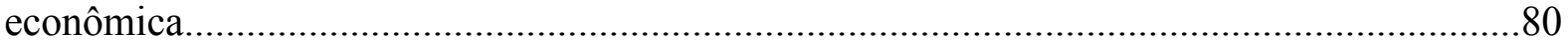

Gráfico 4.11 - Rua 24 de Maio, por idade e por classe econômica.......................................81

Gráfico 4.12 - Rua Barão de Itapetininga por idade e por classe sócio-econômica................81

Gráfico 4.13 - Rua Direita por idade e por classe sócio-econômica....................................82

Gráfico 4.14 - Razões de preferência pelas lojas de rua......................................................83

Gráfico 4.15 - Razões de preferência pelas lojas de rua por classe sócio-econômica.............83 


\section{I - INTRODUÇÃO}

$\mathrm{Na}$ agenda das transformações econômicas recentes, ocupa lugar de destaque a dinâmica da atividade comercial, associada ao intenso ritmo das modificações na organização territorial das grandes cidades.

No município de São Paulo, essas transformações urbanas ocorreram em meio à desindustrialização e ao acentuado desenvolvimento do setor terciário, processos iniciados nos anos setenta e consolidados nas décadas seguintes. Entre os vários serviços ofertados pelo setor terciário, destaca-se o comércio ${ }^{1}$ e, mais especificamente, o varejista, uma atividade cuja relevância não decorre apenas de sua expressão econômica, mas também de sua relação com a dinâmica do espaço urbano, uma vez que representa o elo final da cadeia de abastecimento e o contato direto com os consumidores.

Ao longo do século XX, marcado pela urbanização da sociedade ${ }^{2}$, inúmeras foram as transformações ocorridas no sistema varejista com conseqüências na estrutura das cidades. Se durante o século XIX o consumo se restringia a gêneros básicos, como alimentação e vestuário, mesmo para as elites, no século XXI até mesmo as classes populares têm acesso a uma série de novos bens - advindos do progresso tecnológico e das facilidades proporcionadas pelos sistemas de compra a crédito, desenvolvidas nos últimos 60 anos - como geladeira, fogão, televisão, videocassete, aparelho de som, máquina de lavar roupas, automóvel, criando uma demanda maior para o comércio (VILLAÇA, 1998, p.278).

Em São Paulo, de acordo com PINTAUDI (1992), as transformações urbanas foram mais evidentes pela atração das pessoas à cidade, pela massificação do consumo de

\footnotetext{
${ }^{1}$ Segundo dados do IBGE o setor de serviços nacionais representou, em 2003, 14\%, do Produto Interno Bruto (PIB), o que correspondeu a de 107 bilhões de reais.

${ }^{2}$ O Brasil apresentou intenso processo de urbanização, especialmente na segunda metade do século XX. Até então predominava a população rural, sendo que apenas de $26 \%$ da população do país vivia nas cidades; em 2000 urbana passou para $81,2 \%$.
} 
eletrodomésticos e bens eletrônicos e, principalmente, pela generalização do uso do automóvel, promovida pela grande indústria a partir dos anos cinqüenta.

O surgimento de novos formatos de comércio relaciona-se também com as transformações urbanas, já que a eles está associada uma postura diferente perante o mercado, nomeadamente exigências específicas de localização, diversidade e ampliação de mercadorias para atender uma demanda cada vez maior.

Estes padrões de distribuição de mercadorias, principalmente com a implantação dos supermercados, dos hipermercados e dos shopping centers, implicaram a expansão da cidade, em áreas que tinham como lugar de consumo apenas o pequeno comércio varejista local, o supermercado de bairro, os centros comerciais regionais e o centro tradicional. (ROLNIK, 2000).

Segundo PINTAUDI (1989), o primeiro supermercado surge na cidade de São Paulo, em 1953, o "Sirva-se", trazendo consigo a inovação do auto-serviço, ou seja, os consumidores passaram a ter contato direto com as mercadorias, sem a necessidade de um intermediador. $\mathrm{O}$ surgimento dos supermercados foi marcado pela maciça entrada de indústrias multinacionais no território brasileiro, pelo início da produção em massa de mercadorias e foi o formato comercial que mais impactos trouxe para o espaço urbano. Foi a partir deles que outras grandes superfícies comerciais surgiram, como os hipermercados, destinados à venda não somente de gêneros alimentícios, mas também de roupas, eletrodomésticos e outras mercadorias (BRUNA, 1972, p.227). 
A atividade de shopping centers $^{3}$ na cidade foi a que mais impacto trouxe para o comércio tradicional. Os primeiros shopping centers localizaram-se fora do centro principal da cidade, mas não na periferia, como nos Estados Unidos. Vencida a desconfiança dos lojistas quanto ao conceito inovador após a inauguração do Shopping Center Iguatemi, seu êxito impulsionou a construção de outros shoppings, nas décadas de 70 e 80 , localizados principalmente na zona sudoeste do município de São Paulo, próximos aos bairros de residências das classes de renda mais alta. [(GOMES; PORTUGAL; BARROS, 2004), (VARGAS, 2001, p. 287)]

A partir da década de 80 , pode-se constatar a dispersão dos shopping centers para fora das áreas mais centrais e, por vezes, se localizando em bairros de classes de menor renda, como, por exemplo, o Interlagos (1988) na zona sul, o Aricanduva (1991) e o Penha (1992), na zona leste. Via de regra, se instalaram em locais que privilegiavam o acesso e a concentração demográfica; entretanto, localizações diretamente ligadas às estações de metrô também são uma realidade na cidade, como o Shopping Metrô Tatuapé (1997) e o Shopping Metrô Santa Cruz (2001).

Villaça (1998, p. 303) mostra uma diferença fundamental entre o shopping center e os centros tradicionais (principais ou subcentros). Nestes últimos "a variedade equilibrada é alcançada pelas forças do mercado e, sob a influência dessas forças, acaba não tendo nem lojas de calçados demais, nem lojas de informática de menos; nem dentistas demais, nem escolas de inglês de menos. É o conhecido $\mathrm{mix}^{4}$, a que almejam os shopping centers e o significado

\footnotetext{
${ }^{3}$ De acordo com a Associação Brasileira de Shopping Centers (ABRASCE), desde a implantação do primeiro shopping center brasileiro, o Iguatemi, em São Paulo, no ano de 1966, a quantidade de empreendimentos expandiu-se significativamente no Brasil, principalmente entre 1996 e 2001, quando foi registrado o maior crescimento, com a construção de 93 shopping centers. Em agosto de 2005 o país contava 241 shoppings em operação e 21 em construção, perfazendo um total de 262.

${ }^{4}$ No shopping center, há uma organização, previamente planejada, da distribuição da oferta de produtos e serviços centralizados em seu complexo, o que é chamado de "tenant mix" O "tenant mix" é uma organização especial feita durante a fase de construção do shopping, a qual segue as tendências de mercado, as novidades tecnológicas e determina que tipo de loja (lojas âncoras ou lojas satélites) e que atividade específica estará em que lugar (GAETA, 1988).
} 
dessa variedade equilibrada é reduzir ao mínimo o número de deslocamentos do consumidor”.

Para a arquiteta Heliana Comim Vargas "5 "grande parte da dinâmica e da imagem da cidade é devida ao que é realizado pelas pequenas lojas nas ruas"; "no entanto, a modernidade e a velocidade de mudança do varejo, num mundo globalizado, promovem uma deterioração do varejo tradicional, o qual não se encontra preparado para enfrentar desafios dos grandes varejistas ou dos empreendimentos imobiliários do tipo shopping centers, e mesmo dos ambulantes ${ }^{6}$ ou do $e$-comerce $e^{7 \%}$.

Fator de mudança recente no comércio varejista foi a "descoberta" dos consumidores de baixa renda, sobretudo dos oriundos das classes C, D e E, que representavam, em 2002, 81\% da população brasileira (The Boston Consulting Group [BCG], 2002). Conforme o relatório do BCG, na medida em que as classes A e B vão apresentando sinais de saturação no consumo, as classes C e D surgem como alternativas de expansão para diversos segmentos de mercado.

O comércio varejista, em geral, tem sido abordado por diversos especialistas e com diferentes enfoques, desde consultores, economistas, administradores e empresários, devido à sua importância atual do setor no quadro econômico nacional.

A revisão bibliográfica possibilita constatar lacunas nos textos acadêmicos, sobretudo quando o assunto é relacionado com ruas de comércio no contexto atual da cidade e a sua forma de espacialização, ante as transformações citadas.

\footnotetext{
5 VARGAS, Heliana Comin. "Comércio e cidade: uma relação de origem”. 2002 p.2. Disponível em http://www.estadao.com.br/ext/eleições/artigos/hcomim.htm. Acesso em janeiro/2005.

${ }^{6}$ Trabalhadores ambulantes são distinguidos dos demais trabalhadores de rua pelo fato de não terem o artigo de venda definido e, às vezes, nem mesmo o local.

7 E-comerce ou varejo eletrônico é um formato de varejo que oferece, pela Internet, produtos e serviços, possibilitando que consumidores finais comprem e completem a transação por meio de um sistema eletrônico interativo. $\mathrm{O}$ que diferencia essencialmente o varejo tradicional do varejo eletrônico é a tecnologia envolvida no processo (PORTO apud PARENTE, 2000).
} 
Os incentivos iniciais para realização deste trabalho foram dados sobre pesquisas de comportamento do consumidor no processo de decisão de compra divulgados pelo Instituto de Pesquisas de Mercado Toledo \& Associados $^{8}$. Estas pesquisas revelaram que consumidores de shopping centers na cidade de São Paulo compram roupas de uso pessoal, também, em lojas de rua, onde tradicionalmente se concentra o comércio varejista ${ }^{9}$.No ano de 2004 , de acordo com estas pesquisas, as lojas de rua são mencionadas por $77 \%$ dos entrevistados como outro local, afora Shopping Center, para compras de roupas para uso pessoal (em 2001, foram $62 \%$ ). O preço mais baixo foi considerado por $78 \%$ dos entrevistados o motivo para fazer compras em lojas de rua. Estar passando em frente e proximidade ao lar seriam os motivos seguintes, com $21 \%$ e $17 \%$, respectivamente. Estes dados mostram que, apesar das transformações recentes dos espaços urbanos e dos shopping centers serem fortíssimos como centros de compras, há intenção de consumidores destes mesmos shoppings também efetuar compras em lojas de ruas (TOLEDO, 2004).

Outros estudos sobre comportamento do consumidor, a exemplo do realizado em 2005 pelo Instituto de Estudos e Marketing Industrial (IEMI) ${ }^{10}$, também mostram a importância das ruas de comércio. De acordo com esta pesquisa, a freqüência ao shopping center ainda é de quem tem maior renda: dentre os consumidores classificados pelo instituto como Classe A ouvidos pela pesquisa, $65 \%$ compram em shoppings, contra $27 \%$ em lojas de rua. Por outro lado, dos que possuem menor renda (Classe C e D), $46 \%$ acham melhor comprar na rua contra $35 \%$ em shopping center.

\footnotetext{
${ }^{6}$ Pesquisa MY SHOPPING com objetivo de levantar hábitos dos consumidores de shoppings na cidade de São Paulo e alguns aspectos de sua relação com as ruas comerciais $(2001 ; 2002 ; 2003 ; 2004)$.

${ }^{9}$ A amostra representa consumidores de todas as classes sociais, entretanto, é importante evitar generalizar seus resultados. Este tema será retomado no capítulo 3 desta dissertação.

${ }^{10}$ Fonte: Instituto de Estudos e Marketing Industrial. Disponível em http://www.iemi.com.br/. Acesso em 12/12/2005. Classificação socioeconômica na mesma base adotada pelo IBGE.
} 
A idéia de estudar a dinâmica da rua de comércio foi fortalecida quando verificado o interesse público e privado e a crescente integração de comerciantes através de $\operatorname{programas}^{11}$ que buscam a requalificação e reurbanização urbana dos espaços públicos onde estão localizadas as principais ruas comerciais, principalmente a partir da virada deste século, quando alguns projetos começam a se efetivar ${ }^{12}$.

É importante salientar que os dados estatísticos existentes e os trabalhos acadêmicos consultados não dão grande visibilidade à estrutura econômica atual e específica sobre a dinâmica da rua de comércio e, por vezes, houve necessidade de recorrer às referências feitas em estudos de shopping centers pelo dinamismo e acúmulo de informações que eles oferecem.

\section{OBJETIVO}

O objetivo principal desse trabalho é levantar elementos que configurem a dinâmica da rua de comércio dentro de um contexto de transformações recentes na atividade comercial da cidade de São Paulo.

\section{METODOLOGIA DA PESQUISA E ESTRUTURA DO TEXTO}

O método empregado para estudo da dinâmica da rua de comércio envolve, inicialmente, uma pesquisa bibliográfica realizada para reunir a maior quantidade de informações acerca do assunto estudado, com o objetivo de obter conceitos e denominações utilizadas por profissionais envolvidos no setor do comércio e auxiliar a formação de um conteúdo histórico

\footnotetext{
${ }^{11}$ O Programa de Intervenção em Ruas Comerciais do Município de São Paulo, instituído pelo Decreto no. 42.834 de 06 de fevereiro de 2003 e, posteriormente, consolidado pela Lei 14.003/2005, tem por objetivo realizar melhorias a favor do varejo de rua através de melhorias em calçamento, acessibilidade, paisagismo, comunicação visual, sinalização e mobiliário urbano. A Rua João Cachoeira, primeira obra aprovada, teve sua inauguração em dezembro de 2003. Outras vieram posteriormente, tais como Joaquim Nabuco e Vinte e Cinco de Março. A Rua Oscar Freire encontra-se em obras, com previsão para inauguração ainda no ano de 2006.

${ }^{12}$ Prefeitura e Lojistas Dividirão Gastos com Recuperação de Ruas. Diário do Comércio, 15/06/2005.
} 
e evolutivo. Paralelamente, o trabalho está centrado em estudos de artigos de periódicos de várias áreas de conhecimento, a fim de obter as informações disponíveis mais recentes.

A segunda etapa compreende análise de pesquisas quantitativas sobre o comportamento do consumidor de shopping centers e, através de seu hábito de comprar em lojas de rua, relacionar as principais ruas de comércio na cidade de São Paulo, as categorias de produtos mais procurados, assim como, compreender as razões pelas quais as pessoas freqüentam estas ruas de comércio.

A fase final resulta da conceituação de uma rua de comércio, ante a hipótese, levantada na segunda etapa da pesquisa, de que se a rua de comércio possui capacidade de atrair consumidor de shopping centers, esta deve possuir um mix de lojas ou uma variedade equilibrada de comércio e serviço (Villaça, 1998, p.303). Para esta conceituação é feito o levantamento do mix de lojas da rua Doze de Outubro, que é uma rua comercial de bairro, localizada na Lapa, zona Oeste da cidade de São Paulo, caracterizada, neste trabalho, como um centro comercial não planejado, ou seja, um conglomerado varejista que teve evolução espontânea e atualmente se constitui num das mais importantes do município.

Para construção da pesquisa e entendimento do tema proposto, a dissertação se estrutura em seis capítulos.

O primeiro capítulo aborda os conceitos de comércio, com aprofundamento apoiado na literatura sobre varejo, com a finalidade de relacionar o comportamento do consumidor e a motivação da compra com a localização das áreas comerciais e, a partir destes dados, obter elementos para relacionar os tipos de ruas de comércio.

O segundo capítulo discorre sobre antecedentes históricos do comércio na cidade de São Paulo e transformações recentes. Trata da análise da evolução e a estruturação da rua de 
comércio e sua relação com a expansão urbana. Os novos formatos de varejo e a sua relação com as transformações urbanas são tratados neste capítulo.

O terceiro capítulo traz uma análise do desempenho socioeconômico brasileiro, suas relações com as transformações no comércio e o impacto na rua de comércio.

O capítulo subseqüente identifica as principais ruas de comércio na cidade de São Paulo, mediante análise do comportamento do consumidor pela preferência de determinadas localizações. Neste capítulo a síntese se apóia em pesquisas quantitativas, realizadas no ano de 2004 pelo Instituto de Pesquisas de Mercado Toledo \& Associados.

Compreender a configuração de uma rua de comércio é o objetivo do quinto capítulo. Considera as transformações decorrentes de um início de processo de revitalização de ruas de comércio e o significado da "variedade equilibrada" ou mix de lojas da rua de comércio.

Por fim, são apresentadas as considerações finais, a necessidade de aprofundamento em algumas questões e as possibilidades de direcionamento de futuras pesquisas. 


\section{CONCEITUAÇÃO GERAL}

O comércio é um tema complexo e envolve diferentes conceitos e formas de abordagens e, devido à importância do setor, especialmente nas últimas décadas, no quadro econômico nacional, tem sido objeto de inúmeros trabalhos acadêmicos com diferentes enfoques. Pela necessidade de tematização do trabalho, foram privilegiados, na pesquisa bibliográfica, assuntos relacionados com o comércio varejista e o processo geral de formação e transformação do espaço urbano.

Este capítulo tem como objetivo descrever aspectos pertinentes ao desenvolvimento da pesquisa e os fatores que contribuem para definição da dinâmica da rua.

\subsection{Conceito de Comércio}

De acordo com o Instituto Brasileiro de Pesquisas Econômicas - IBGE, comércio é toda ação que tem como objetivo principal a compra e revenda de mercadorias. Comércio é, portanto, o conjunto de atividades necessárias para tornar um produto disponível aos consumidores, em determinado lugar, no tempo solicitado e em quantidades e preços especificados.

A atividade comercial se subdivide em duas partes distintas: o comércio atacadista e o comércio varejista. O primeiro funciona basicamente como centro de distribuição de mercadorias para o comércio varejista, para que este último atenda sua finalidade específica, que é fornecer ao público os produtos necessários.

Existem várias definições para o termo varejo. De acordo com TERRA (2001, p.6) a definição mais abrangente é apresentada por Phillip Kotler (1993) e diz que “o varejo inclui todas as atividades envolvidas na venda de bens ou serviços diretamente aos consumidores finais para uso pessoal", e que "não importa a maneira pela qual os bens ou serviços são 
vendidos (venda pessoal, correio, telefone ou máquina automática ), ou onde eles são vendidos (loja, rua ou residência)"

Parente (2000) define varejo como todas as atividades que englobam o processo de venda de produtos e serviços para atender necessidades pessoais dos consumidores finais dos mesmos.

O varejo, como operação comercial de distribuição direta ao consumidor, está constantemente se adaptando aos seus hábitos, costumes e necessidades. Desse modo, o sistema varejista reúne, em locais adequados, produtos oriundos das mais diversas origens, procurados pelos consumidores de modo a suprir a compra dos bens que eles necessitam e desejam, a preços razoáveis e em locais apropriados à sua comodidade (BRUNA, 1972).

A partir destas definições, pode-se concluir que o varejo tem como condição básica para a sua prática a comercialização de produtos e serviços a consumidores finais, não importando a natureza da organização que o exerce ou o local onde está sendo praticado.

Para fins deste trabalho, quando houver referência ao comércio, entenda-se como comércio varejista (retailling), considerando, como tal, qualquer estabelecimento que pratique a venda direta de produtos ao consumidor, bem como os serviços por analogia varejistas.

Neste estudo optou-se pela terminologia "rua de comércio" para fazer distinção do comércio informal, para o qual é utilizado o termo "comércio de rua". Freqüentemente, ao referenciar "rua de comércio", haverá necessidade de citar termos como "lojas de rua" ou "comércio tradicional", para os quais o entendimento deve ser similar. 


\subsection{Localização do comércio}

A atividade econômica apresenta um estreito relacionamento com o espaço físico que lhe dá suporte, criando o que chamamos de localização. Assim, o processo de mudança econômica é, ao mesmo tempo, causa e efeito dos padrões espaciais existentes (VARGAS, 2001, p. 49).

Estudos sobre teorias da localização, bem como os modelos propostos para conceituar área de influência, não se enquadram nos objetivos deste estudo, que não tem como foco planejamento de centros comerciais, para os quais estas teorias são fundamentais. Especificamente os conceitos dos itens seguintes estão relacionados aos assuntos pertinentes à localização e à definição de área de comércio.

Vários autores ofereceram definições do conceito sobre área de comércio. Segundo LIMA FILHO (1975, p.19), elas vão desde proposições simples, tais como a de Manoel Plottkin ${ }^{13}$, que se refere à área de comércio como "a área geográfica a partir da qual uma loja atrai seus clientes" e a de Jac Goldstucker ${ }^{14}$, que a define como "espaço geográfico no qual os custos de contrato entre compradores e vendedores são mínimos, de modo que a satisfação tanto dos consumidores como dos comerciantes deve ser ótima”, até formulações como a de La Londe $e^{15}$, que expandiu esse raciocínio e introduziu os conceitos de probabilidade e movimento no espaço, estudados por William Reilley, Paul D. Converse e David Huff ${ }^{16}$.

Huff define a área de comércio como:

“[...] uma região delineada geograficamente, contendo consumidores potenciais para os quais existe uma probabilidade maior do que zero de comprar produtos e serviços, vendidos por uma firma ou um aglomerado de firmas". (HUFF, 1964, p.28).

\footnotetext{
13 PLOTTKIN, Manuel D. "The Use Credit Accounts and Computers in Determining StoreTrading Areas". 1965 , p. 271.

${ }^{14}$ GOLDSTUCKER, Jac. “Trading Areas, em Science in Marketing”. 1965, p. 282.

${ }^{15}$ LONDE, Bernard J.La. "Differential in Super Market Drawing Power, Marketing and Transportation MSU”, 1962, p.59.

${ }^{16}$ Cf. HUFF, David L. "Deining and Estimating a Trading Área”, Journal of Marketing. Julho, 1964, pp.27-58.
} 
Segundo o Urban Land Institute (ULI) [(1971)], o termo área de comércio é normalmente definido como:

"[...] aquela área que obtém maior proporção de clientela contínua necessária para manutenção constante do centro comercial. Os limites desta área são determinados por fatores, como: natureza do próprio centro, acessibilidade, barreiras físicas, limitações de tempo e distância, poder de atração e competição". (ULI, 1971).

As definições acima mostram que os esforços no sentido de entender os vários aspectos que determinam uma área comercial, de uma forma geral, são em função da localização e seu respectivo poder de atração de potenciais consumidores.

Os primeiros estudos sobre localização do comércio foram feitos, tomando como objeto a Teoria do Lugar Central, desenvolvida por Walter Christaller ${ }^{17}$, no início dos anos 30 . Buscando explicar uma ordem aparente na distribuição espacial dos centros comerciais, seu postulado, além de criar o conceito da área de influência, estabeleceu níveis hierárquicos de centros definidos de acordo com tamanho desta área de influência, relacionada com a densidade e a renda da população e distância (VARGAS, 2001, p.61).

Como enfatiza VARGAS (2001, p.64), a evolução das teorias e a ampliação das áreas de conhecimento voltadas para o tema ${ }^{18}$ mostram uma mudança da ênfase locacional para a ênfase na administração do negócio, com o fortalecimento de "marcas" e do sistema de franquias, que passam a funcionar como âncoras dos shopping centers, com privilégios semelhantes aos das tradicionais lojas de departamentos.

Dentre o conjunto de métodos concebidos por pesquisadores com propósito de solucionar problemas sobre o comportamento de compras do consumidor e as formulações de teorias

\footnotetext{
${ }^{17}$ Maiores detalhes podem ser verificados em MASANO, Tadeu Francisco. Shopping centers e suas relações físico-territoriais e sócio - negociais no município de São Paulo. Tese apresentada à FAU USP, 1993, pp.46-79.

18 Para obter estas conclusões, Vargas apresenta breve histórico dos estudos, teorias locacionais e menciona diversos autores, com destaque para o trabalho Retailling Mangement (Davidson et al. ,1988), que se tornou clássico para estudos varejistas que analisam vários aspectos da administração, localização, estabelecimentos e mercados e para as os estudos de marketing de Philip Kotler.
} 
sobre localização de centros comerciais, as contribuições de Richard Nelson ${ }^{19}$, na década de 50, são as que proporcionam alguns critérios que podem auxiliar na avaliação de uma rua de comércio.

Richard Nelson mostra que o valor de um "ponto" depende, além da acessibilidade da população residente e em deslocamento, da atração física da loja, do uso do solo do entorno e da qualidade dos produtos oferecidos, o que lhe permitiu desenvolver um conjunto de oito princípios básicos para a elaboração de um check list, que visa analisar o ponto onde uma loja poderá ser localizada, bem como a concorrência existente (FRUGOLI JR, 1998, p.56; MASANO, 1993, p.56; VARGAS, 2001, p.63).

Os oito princípios básicos propostos por Richard Nelson (1958) são apresentados a seguir e consistem em:

Potencial da área: Determinar a área comercial, contar as pessoas para estimar a densidade da demanda e o poder de compra.

Acesso: Verificar acessibilidade. Disponibilidade de transportes públicos. Considerar a geração de negócios, suscetíveis de atração à vizinhança.

Potencial de crescimento: Verificar se o local está em área onde a população e a renda estão crescendo, visando aos resultados futuros.

Interceptação de negócios: Averiguar se o ponto está entre o local onde as pessoas moram e o local onde tradicionalmente compram, de forma a vir a interceptar clientes em sua trajetória, ou seja, localizar o negócio no caminho percorrido pelos consumidores.

Atração cumulativa: Aplicar o conceito de que o consumidor prefere comparar diversas lojas antes de efetuar a compra, principalmente para itens em que preço, padrão, qualidade e moda são considerações importantes, ou seja, lojas próximas, que atendem a esses requisitos, podem atrair mais negócios do que as localizadas em separado.

\footnotetext{
${ }^{19}$ NELSON,Richard. “Retailing Location, Principles and Methods”, 1958, pp.191-193; 329-356.
} 
Compatibilidade: Procurar maximizar a incidência da proximidade de negócios compatíveis para aumentar o intercâmbio de clientes. A medida da compatibilidade está ligada a questões do tipo: o negócio "A" ajuda o negócio "B" ao lado? Ele prejudica "B” ou não causa efeito aparente?

Risco mínimo de concorrência: Selecionar locais onde haja mínima interceptação de clientes pela concorrência e considerar a possibilidade de controlar os locais que tenham esse risco.

Aspectos microeconômicos: Analisar o local em termos de custos, produtividade, rentabilidade e crescimento futuro, considerando aspectos técnico-econômicos e comerciais.

De um modo geral, a localização de unidades comerciais está relacionada com a concentração de atividades em um determinado espaço físico, o que resulta em uma área de comércio, com poder de atração de potenciais consumidores.

O fator localização deixa de ser relevante para os tipos de varejistas que operam sem loja, tais como empresas de catálogo, ou para os varejistas virtuais, que comercializam por meio da internet. Esses modelos conseguem alcançar seus consumidores independentemente de sua localização física. (PARENTE, 2000, p. 325)

\subsection{Classificação do comércio varejista}

A classificação do comércio para todos os tipos envolvidos com o setor varejista é muito abrangente. Parente demonstra preocupação com as diversas formas de varejo na frase: "Quando se fala em varejo, logo surge na mente a imagem de uma loja: porém, as atividades varejistas podem ser realizadas também pelo telefone, pelo correio, pela internet e também na casa do consumidor”.(PARENTE, 2000, p.22)

A classificação inicial utilizada pela Gerência Setorial de Comércio e Serviços do BNDES- e neste aspecto existe consenso entre diferentes autores, como Walters [apud Toledo \& Batista, 
1996, p.124]; Las Casas (2001) ; Kotler e Armstrong (2000), Parente (2000)- toma como base os recursos físicos empregados no contato com os compradores finais e considera duas modalidades: varejo com loja (store retailers) e varejo sem loja (nonstore retailers), para então evoluir na subsegmentação.

\subsubsection{Comércio com lojas}

O comércio com lojas é segmentado de diversas formas, dependendo do enfoque da pesquisa. Pode-se classificar conforme a área, por exemplo; as lojas podem ser pequenas, médias ou grandes. Pode-se, também, classificar de acordo com a localização (lojas de rua; galerias comerciais ou shopping centers), com o deslocamento (conveniência; preço ou rotina), ou pelo mix de produtos (especializado x não especializado; alimentos x não-alimentos; seleção assistida x auto-serviço; vizinhança x não-vizinhança). [(BNDES, 2000); PARENTE, 2000].

De uma forma geral, o comércio tem sido classificado em função da localização. A classificação proposta por Parente (2000, pp. 332-335) contempla três alternativas: centro comercial não planejado, centro comercial planejado e loja isolada. Os centros comerciais não planejados são pontos que tiveram sua evolução espontânea por algum motivo, como, por exemplo, proximidade do mercado consumidor. Já os centros comerciais planejados são projetados com um objetivo, como oferecimento de produtos específicos e variados. Os shopping centers se enquadram neste conceito e caracterizando-se como um empreendimento desenvolvido especificamente para formar um complexo comercial integrado, composto de várias unidades varejistas, que oferecem uma linha de produtos variados e complementares, constituindo-se em locais não só para compras, mas também para lazer, alimentação e socialização. As lojas isoladas, ou Free Standing, não possuem outras lojas vizinhas para aumentar sua atratividade, podendo estar em avenidas ou outros pontos de grandes fluxos de pessoas, ou por outro motivo estratégico. 
A tabela 1.1. resume os tipos, conceitos e exemplos sob a visão de Parente (2000, p.337) e Kotler (1998, p.507).

\begin{tabular}{|c|c|c|c|}
\hline Tipo de Comércio & \multicolumn{2}{|l|}{ Conceito } & Exemplos \\
\hline \multirow{4}{*}{$\begin{array}{l}\text { Centro comercial } \\
\text { não planejado }\end{array}$} & \multirow{4}{*}{$\begin{array}{l}\text { Locais onde exista } \\
\text { concentração de lojas } \\
\text { com evolução } \\
\text { espontânea }\end{array}$} & $\begin{array}{l}\text { Zona Comercial } \\
\text { do Centro da } \\
\text { Cidade }\end{array}$ & $\begin{array}{l}\text { Rua Direita } \\
\text { Rua São Bento; } \\
\text { Rua Barão de Itapetininga; } \\
\text { Rua } 24 \text { de Maio }\end{array}$ \\
\hline & & $\begin{array}{l}\text { Zona Comercial } \\
\text { de Bairro }\end{array}$ & $\begin{array}{l}\text { Santana (rua Voluntários da Pátria), Santo } \\
\text { Amaro (Largo Treze), Pinheiros (rua Teodoro } \\
\text { Sampaio), Lapa (rua Doze de Outubro), }\end{array}$ \\
\hline & & $\begin{array}{l}\text { Zona Comercial } \\
\text { de Vizinhança }\end{array}$ & $\begin{array}{l}\text { Ruas com pequena concentração de lojas de } \\
\text { produtos de conveniência: farmácia, açougue, } \\
\text { padaria. }\end{array}$ \\
\hline & & $\begin{array}{l}\text { Concentração em } \\
\text { um tipo de } \\
\text { produto }\end{array}$ & $\begin{array}{l}\text { Ruas especializadas: rua São Caetano } \\
\text { (vestidos de noiva); Rua da Consolação } \\
\text { (lustres); Rua Teodoro Sampaio (móveis) }\end{array}$ \\
\hline $\begin{array}{l}\text { Centro comercial } \\
\text { planejado }\end{array}$ & \multicolumn{2}{|c|}{$\begin{array}{l}\text { Empreendimentos desenvolvidos } \\
\text { especificamente para formar um complexo } \\
\text { comercial com um composto de produtos } \\
\text { variados }\end{array}$} & $\begin{array}{l}\text { Shopping center } \\
\text { Hipermercados } \\
\text { Minishopping localizados em Metrô, } \\
\text { Aeroportos ou Estações Rodoviárias } \\
\text { Postos de Gasolina }\end{array}$ \\
\hline Lojas isoladas & \multicolumn{2}{|c|}{$\begin{array}{l}\text { Não contam com outras lojas próximas para } \\
\text { alavancar sua atratividade }\end{array}$} & $\begin{array}{l}\text { Lojas de Materiais de Construção: Telhanorte; } \\
\text { C\&C } \\
\text { Clubes de Compras - Makro; Sam's Club }\end{array}$ \\
\hline
\end{tabular}

Tabela 1.1 Tipos de Comércio

Fonte: Elaborado pela autora, com dados de PARENTE (2000) e KOTLER (1998).

Esta classificação e seus conceitos são adotados neste estudo, os quais, observadas as limitações e necessidades de adaptações intrínsecas ao tema, permitem identificar os tipos de ruas de comércio ${ }^{20}$ na cidade de São Paulo,

\subsubsection{Tipos de Ruas de Comércio}

Por analogia à definição do comércio não planejado - um conglomerado varejista com evolução espontânea, desenvolvido, em geral, em locais de concentração demográfica e em torno das interseções das malhas viárias das cidades - os tipos de comércio constantes da tabela $1.1^{21}$ são utilizadas para classificar as ruas de comércio ${ }^{22}$ em São Paulo.

\footnotetext{
${ }^{20}$ Detalhados apenas os tipos ruas de comércio, foco deste estudo.

${ }^{21}$ Com as devidas adaptações da terminologia "zona" pelo termo "rua".

${ }^{22}$ Villaça (1998) ao referir-se ao comércio tradicional associa ao termo "subcentro" a rua de bairro e usa o termo "centro principal" para designar o centro histórico. Neste trabalho, essas outras duas formas de abordagem poderão ser frequentemente citadas para referir-se a rua comercial do centro ou rua comercial de bairro.
} 
Rua comercial do centro: é desenvolvida ao redor da região para onde, em geral, convergem os sistemas de transporte público e constitui-se no complexo comercial não planejado mais importante quando nele se concentra a maior oferta varejista, principalmente de lojas especializadas.

Rua comercial de bairro: é o aglomerado comercial formado em interseções e vias de intensa circulação de transporte coletivo, em bairros residenciais.

Rua comercial de vizinhança: é um aglomerado varejista menor, localizado em torno de vias principais de regiões predominantemente residenciais, formado por um pequeno complexo de lojas direcionadas para a comercialização de produtos de conveniência, como: farmácias, padarias, rotisserias, quitandas, açougues, supermercados, postos de gasolina, lojas de conveniência e lojas de prestadores de serviço, como, por exemplo, agências bancárias, lavanderias, salões de beleza, correios, videolocadoras, copiadoras, chaveiros.

Rua especializada em um tipo de produto e que se dá através de concentração de lojas especializadas.

\subsubsection{2 - Tipos de Lojas}

Os tipos de loja são classificados em virtude da quantidade de linhas de produtos $^{23}$ (Parente, 2000). Os tipos de lojas que reúnem os conceitos que resumem as situações mais recentes, focados no objetivo desta pesquisa, são os seguintes:

Lojas de Especialidade (ou Lojas Especializadas): englobam, em geral, pequenos ou médios estabelecimentos, localizados em centros comerciais de rua ou shopping centers. São dedicadas à venda de linhas de produtos específicos, oferecendo uma grande variedade de itens. Constituem o maior número de lojas brasileiras e isto se deve à grande variedade de

\footnotetext{
${ }^{23}$ Para obter conceituações sobre varejo alimentício e varejo de serviço bem como sobre outras formas de segmentação de varejo com loja, consultar PARENTE, Juracy. "Varejo no Brasil” (2000, pp. 25-36) e "A Segmentação do Comércio Varejista" - Relatório nº 12 - BNDES (2000).
} 
tipos e formatos. Podem posicionar-se nos mais variados segmentos, desde no de loja de presentes sofisticados, para a classe A, até no de loja de confecções femininas, direcionada para a classe D. Variam em dimensões, conforme a necessidade e o mix de produtos.

Lojas de Departamentos: são lojas que oferecem variedade e um grande número de linha de produtos, desde vestuário e acessórios até eletrodomésticos e móveis. Cada linha possui seu departamento separado. Tradicionalmente, as lojas de departamento ofereciam uma linha completa. Mappin e Mesbla foram exemplos clássicos deste formato de loja. As lojas de departamento de linha completa, atualmente, não têm presença na cidade de São Paulo.

Lojas de Departamento de Linha Limitada ${ }^{24}$ ou Magazines: são modelos compactos de lojas de departamento que concentram um número menor de departamento. Trata-se de uma tendência atual de lojas, como a Renner, a C\&A, a Riachuelo, a Pernambucanas, com conceito de lojas de departamentos, porém de linha limitadas e especializadas em confecções; a Casas Bahia, especializada em móveis e eletrodomésticos. Inclusive, quando ocupam áreas maiores vêm permitindo a introdução do conceito de "megalojas", como a Loja Ponto Frio e a Loja Tok \& Stock (recém inaugurada) na marginal Tietê, assim como a Etna, a Avenida Chucri Zaidan.

Lojas de Descontos: as lojas de desconto vendem grandes volumes de mercadorias normalmente a preços mais baixos, com margens de lucro menores, estão localizadas, geralmente, em áreas de grande afluxo de pedestres. Algumas vezes denominadas "lojas de departamentos de desconto", operam com linhas básicas de vestuário, junto com artigos de bazar, brinquedos, pequenos eletrodomésticos, dentre outros, tendo como enfoque principal o

\footnotetext{
${ }^{24}$ Terminologia adaptado pela autora da definição de "miniloja de departamento" de PARENTE (2000), em que ele próprio conceitua como loja de departamento de linha limitada e reconhece não ser muito clara a linha divisória entre uma miniloja de departamento e uma loja especializada.
} 
preço, com mercadorias de baixo valor unitário. A Lojas Americanas é a que mais se aproxima como exemplo.

Lojas de Franquias: é um formato de loja no qual o franqueador (aquele que possui o produto, serviço ou método de trabalho) concede licença de comercialização a franqueados (empreendedores afiliados), oferecendo assistência na organização do negócio em troca de remuneração.

Lojas de conveniência - são classificadas, como de conveniência, aquelas lojas do ramo alimentício combinada com produtos diversos, geralmente não destinados para consumo no local de compra. Empresas do setor de combustível são responsáveis pelas principais marcas no mercado brasileiro. Drogarias e padarias são modelos atuais que enquadram neste formato.

\subsubsection{Comércio sem loja}

Existem vários tipos de comércio sem loja - desde o sistema de marketing interativo, que usa veículos de comunicação para realizar vendas, como TV shopping, Televendas; o de venda direta ao consumidor através de empresas que se apóiam integralmente nesse sistema, como Avon, Natura; o de máquinas automáticas que vendem café, refrigerantes, fitas de vídeo - até o varejo eletrônico.

O varejo eletrônico também chamado de $e$-commerce ${ }^{25}$ é qualquer forma de transação comercial em que as partes interagem eletronicamente. Trata-se de um conjunto de técnicas e tecnologias computacionais, utilizadas para facilitar e executar transações comerciais de bens e serviços através da internet.

\footnotetext{
25 Fonte: Glossário. Cartilha de Segurança para Internet. .Disponível em $<$ http://www.terra.com.br/informatica/especial/cartilha/> Acesso em acesso em 03/03/2006.
} 
Ao desenvolver analogias entre varejo virtual e varejo com lojas, verifica-se que muitos aspectos do varejo com lojas encontram sua contrapartida no varejo virtual. Ao visitar uma loja, vê-se primeiro a sua fachada e decoração externa (vitrine). No varejo virtual é a home page que primeiro desperta a atenção. Da mesma forma que o consumidor percorre os corredores para procurar e selecionar produtos, também, na loja virtual, por uma busca sucessiva de informações, descobre detalhes sobre os produtos que lhe interessam, assim como forma de pagamento.

Pela enorme expansão das compras virtuais, o varejo sem loja vem crescendo mais rapidamente do que o varejo com loja. (PARENTE, 2000, p.35). Segundo levantamento do IBGE, com base nos meses de setembro de 2003 e setembro de 2004, o comércio tradicional registrou o crescimento de $8,87 \%$. Segundo a consultoria e-bit ${ }^{26}$, que acompanha o desenvolvimento do comércio eletrônico no Brasil, desde abril de 2000, o varejo virtual registra crescimento cerca de cinco vezes maior, atingindo $45 \%$. A maior parte das vendas varejistas, entretanto, ainda é realizada por lojas; o varejo eletrônico, em 2003, representava cerca de $3 \%$ de todo o comércio no país.

De acordo com o IBOPE//NetRatings ${ }^{27}$, quando considerados múltiplos locais de acesso, cerca de $11 \%$ - dos 32 milhões de brasileiros que utilizaram a internet no primeiro semestre de 2005 - declararam ter realizado compras on-line. Há um ano, eram apenas $6 \%$, o que indica a velocidade do crescimento desta modalidade de varejo no país (IBOPE, 2005).

\footnotetext{
${ }^{26}$ A $e$-bit é uma empresa de marketing online focada na realização de pesquisas sobre hábitos e tendências de $e$ commerce no Brasil. Estudo realizado pela e-bit, com o apoio da Câmara Brasileira de Comércio Eletrônico (Camara-e.net), apontou crescimento de 43\% de 2004 para 2005. Desde 2001, data em que o estudo começou a ser realizado, o varejo eletrônico cresceu 355\%. Fonte: Câmara Brasileira de Comércio Eletrônico. Disponível em: http://www.camara-e.net/interna.asp Acesso em 02 /02/2006.

${ }^{27}$ Fonte: Consumo, IBOPE Inteligência, IBOPE Mídia, IBOPE//NetRatings, Internet, Investimento Publicitário. Notícias. 20/10/2005<http://www.ibope.com.br/ > acesso em fevereiro 2006.
} 
Apesar do crescimento registrado pelas pesquisas mencionadas acima, na avaliação de COSTA (2003), o número de pessoas com acesso à internet no Brasil é pouco expressivo ${ }^{28}$, mas a popularização do comércio eletrônico é previsível, uma vez que se trata de um canal de vendas recente, com um grande potencial a ser explorado.

Em matéria de vendas, existem empresas que operam lojas físicas e comércio virtual, como, por exemplo, a Lojas Americanas, que atua no setor do varejo de descontos e que estimula a concorrência a baixo custo no meio eletrônico; o canal virtual do Ponto Frio, e o Magazine Luiza, cuja loja virtual é uma das maiores da rede.

\subsection{Hábitos de compra}

As decisões de onde e como comprar são influenciadas por variáveis, como fidelidade a marcas e lojas, tempo disponível para a compra, características do produto, processo de compra adotado pelo consumidor, horário de funcionamento, localização, entre outros aspectos (PARENTE, 2000, p.128).

Ao visitar uma loja, o consumidor pode ou não concretizar uma compra. O resultado da decisão depende do estilo de compra do consumidor. Apesar de as motivações que predominam durante a aquisição de um produto serem individuais e muitas vezes de natureza subjetiva, ainda assim, podemos relacionar os tipos mais comuns de compra ${ }^{29}$ :

Compra Planejada (ou por conveniência): é aquela que o consumidor já havia planejado antes de entrar na loja. Tem um motivo inicial e está ligado à proximidade, ou seja, já existe um propósito de compra. Compras em supermercados, quando o cliente faz antecipadamente

\footnotetext{
${ }^{28}$ Para detalhes veja COSTA, Filipe Campelo Xavier da - "Relacionamento entre influências ambientais e o comportamento de compra por impulso: um estudo em lojas físicas e virtuais”. Tese doutorado FEA. 2003.

${ }^{29}$ Definições baseadas nos conceitos de PARENTE (2000) e VARGAS (2001).
} 
uma lista dos produtos a serem adquiridos, ou farmácias e drogarias, onde as receitas médicas exercem o papel da lista, são exemplos de compra planejada.

Compra por Impulso: ocorre quando o consumidor, por alguma razão, decide, dentro da loja, comprar algo que não estava previsto, seja na lista escrita no papel, ou na intenção da visita. Itens comprados de forma espontânea e não premeditada, sem avaliação de necessidades, integram esta modalidade ligada à intensidade de fluxo e à localização estratégica do local de compra. Existem muitas situações em que o comportamento de compra situa-se na fronteira entre compra planejada e por impulso, como, por exemplo, quando planeja comprar um item, mas acaba levando mais para aproveitar uma promoção, ou quando não encontra a marca preferida e decide levar um substituto.

Compra Comparada: neste processo o consumidor despende razoável esforço na busca de informações para fazer comparações em termos de preço, estilo, qualidade e outras características que dizem respeito a produtos, geralmente, com ciclo de consumo mais longo. São características de grandes centros especializados, onde o fluxo é criado.

Os tipos de compras relacionados acima reproduzem, em grande parte, conceitos trazidos por Richard Nelson ${ }^{30}$, segundo os quais o volume de negócios de um sistema varejista seria o resultado de três tipos de atração (BROWN, 1992 apud ARANHA, 2001, p33): atração geradora, ou vendas atraídas pela loja em si; atração de vizinhança ou vendas conseguidas pela loja devido à força de atração de consumidores das lojas vizinhas e atração suscetível, que não é estimulada pela loja ou seus vizinhos, mas atraídas por impulso durante o deslocamento das pessoas.

A conceituação para esses três tipos de negócios pode ser exemplificada de uma forma clássica (ARANHA, 2001, p33): para o primeiro tipo (negócios gerados) “o consumidor vai à

\footnotetext{
${ }^{30}$ NELSON, Richard L. in "Retailing Location, principles and methods", 1958, p.45.
} 
padaria para comprar pão"; “após comprar pão, compra- se carne no açougue ao lado”; ou seja, padaria e açougue se beneficiam com a proximidade um do outro, constituindo o segundo tipo (negócios compartilhados) e, finalmente, o terceiro tipo de negócio "ao ir à padaria e depois ao açougue, compra-se, por impulso, uma revista na banca de jornal”.

Entretanto, considerando-se que, atualmente, o modo como o comércio acontece é diferente de um local para outro, como também diferem entre si os impactos de cada pólo na cidade, esse tipo de exemplo já não condiz com a realidade. A padaria de hoje se tornou um formato varejista peculiar, não é mais apenas o local de venda de pães e confeitaria. Atravessa intenso processo de modernização e, na maioria das vezes, oferece uma enormidade de produtos, desde café da manhã, almoço self-service, revistas, enfim, insumos para atender às necessidades de conveniência do consumidor e assim sendo, na própria padaria, pode-se comprar pão, fazer a refeição, comprar a revista. Exemplo similar é o que acontece com as drogarias e com os postos de gasolina, que refletem o conceito de lojas de conveniência.

Estes novos formatos de comércio confirmam novas tendências elucidadas por PARENTE (2000, p.19) quando afirma que a "busca da conveniência" e a "falta de tempo" são características marcantes que vêm moldando o comportamento e hábitos de compra. Quando se valoriza o tempo, a conveniência não está diretamente relacionada com a proximidade geográfica, mas sim, com a possibilidade de comprar com rapidez, se essa for a vontade do consumidor. A compra através da internet, além da comparação de preços, apresenta-se como uma opção capaz de oferecer a conveniência desejada pelos consumidores (SIQUEIRA, 2004, p.27). O seu crescimento poderá vir a afetar o fluxo das ruas de comércio na medida em que o consumidor deixar de freqüentar a loja física ${ }^{31}$.

\footnotetext{
${ }^{31}$ Pesquisa realizada pela e-bit revelam que $93 \%$ de consumidores estimaram como alta a probabilidade de voltar a fazer compras na mesma loja virtual e assinalaram que as principais razões para comprarem pela internet é a facilidade de comprar a qualquer hora e em qualquer lugar, sem enfrentar transtornos, como filas em lojas e congestionamentos nas ruas Fonte: "O varejo virtual já atinge o equilíbrio" Jornal GAZETA MERCANTIL; 24 de junho de 2003.
} 


\section{TRANSFORMAÇÕES DO COMÉRCIO E EVOLUÇÃO URBANA NA CIDADE DE} SÃO PAULO

Neste capítulo é abordada a evolução urbana da cidade de São Paulo, tendo como núcleo central as transformações da atividade varejista. Essa exposição obviamente não poderia ser feita para o entendimento da totalidade da vasta história da expansão urbana da cidade. Impõe-se aqui uma decisão metodológica, ou seja, extrair e resumir fatos e informações relevantes, para estabelecer parâmetros desejados quanto ao objetivo de analisar a dinâmica da rua de comércio.

Nessa perspectiva de estudo dois fatores são destacados. O primeiro deles tem como referência o conteúdo histórico e a formação do comércio tradicional; as primeiras ruas comerciais e principais atividades desenvolvidas; seu deslocamento para outros núcleos da área urbana como uma tendência locacional não planejada; o desenvolvimento do comércio regional de bairro ou o subcentro comercial; o ajustamento do sistema varejista dado pela concentração de funções comerciais específicas e a formação das ruas especializadas e, por fim, a integração das galerias comerciais à dinâmica das ruas centrais de São Paulo.

O segundo elemento diz respeito ao surgimento de novos formatos de varejo, sua constante transformação e derivações na evolução urbana da cidade, com destaque para o desenvolvimento das lojas de departamentos, a implantação e evolução do auto-serviço e dos supermercados, culminando com mudanças mais recentes do sistema varejista trazidas com os hipermercados e os shopping centers, empreendimentos totalmente focado no consumidor e ambientes e localizações planejados. 


\section{1 - A formação do comércio tradicional: primeiras ruas comerciais e principais atividades desenvolvidas.}

O principal fator condicionante das transformações envolvendo o aumento de comércio e serviços foi, obviamente, a existência de demanda (ZMITROWICZ, W. 1979 p.53).

Desde a fundação da cidade de São Paulo, em 1554, até a segunda metade do século XIX, a demanda por comércio era muito pequena em conseqüência do reduzido tamanho da população, seu pequeno poder aquisitivo e o baixíssimo padrão de consumo da época, restrito quase que aos gêneros alimentícios ou de primeira necessidade, que eram obtidos graças ao fluxo de mercadorias entre o interior e o litoral.

A função comercial da cidade se concentrava particularmente em duas ruas do velho núcleo: a Rua da Quitanda e a rua das Casinhas (atual Largo do Tesouro). Seus nomes eram bastante significativos, pois na primeira eram vendidos legumes, as frutas e as mercadorias de consumo imediato, ao passo que a segunda exibia um modesto comércio de rua, onde se alinhavam "vendas em pequenas casas isoladas, fornecendo farinha, toucinho, arroz, milho, carne-seca”. (AZEVEDO, 1958, p. 61).

O ciclo da venda através da lojinha teve longa duração, prolongando-se pela maior parte do século XIX (AB'SABER, 2004, p.347).

O final do século XIX representa para São Paulo uma época de profundas mudanças, nas quais três fatores aparecem nitidamente entrelaçados e que contribuíram para sua transformação num importante centro comercial: a expansão da lavoura cafeeira em várias regiões paulistas, a construção da estrada de ferro Santos-Jundiaí (1867) e o afluxo de imigrantes europeus (AB'SABER, 2004, p.347). 
A capital passou a ser o elo de transporte, de negócios e agenciamentos, que articulava o interior, o litoral e os mercados europeus, o que, por sua vez, gerava um movimento comercial dinâmico e diversificado. Com o café e o conseqüente surgimento de uma elite mais urbana e enriquecida, surgiu uma demanda por produtos e serviços mais sofisticados.

Esse primeiro crescimento da demanda foi responsável principalmente pela transformação do "triângulo histórico" ou "triângulo central" da cidade - formado pelas ruas Direita, São Bento e Quinze de Novembro - em área comercial (HOMEM, 1980, p.63).

A rua da Imperatriz (atual rua Quinze de Novembro), durante muito tempo foi a principal artéria do chamado "triângulo", quando o centro era só o encontro dessas três citadas ruas.

A rua da Imperatriz atraiu os estabelecimentos de comércio e serviços, que disputavam as posições de melhor acesso às camadas de mais alta renda, e tornou-se a primeira manifestação do centro comercial da cidade de São Paulo (VILLAÇA, 1998, p.262).

Era a preferida para "footing" (passeios) e nela se concentravam os cafés, restaurantes, confeitarias, casas importadoras, bancos, além das grandes casas comerciais consideradas luxuosas para a época, como a Casa Garraux, uma das maiores lojas gerais ${ }^{32}$ da época.

Tendo em vista o panorama de meio século antes, verifica-se de quão longe ficava o tempo em que o comércio se concentrava na rua da Quitanda e ao longo da rua das Casinhas. "Em 1877 foram expulsos os quitandeiros da rua das Casinhas, a qual, tornada Largo do Tesouro, passou a ser ladeada de lojas e escritórios”. (MONBEIG, 2004, p 50)

Com a inauguração da ferrovia, a população em trânsito e a população permanente da cidade aumentaram rapidamente. Para se ter uma idéia do crescimento vertiginoso da cidade na

\footnotetext{
${ }^{32}$ Lojas gerais, ou general stores, , são tipos de lojas grandes, que vendiam um pouco de tudo, mas, ao contrário das lojas de departamentos - suas sucessoras -, eram operadas pelo próprio dono e sua família e não apresentavam qualquer estruturação operacional interna.
} 
virada do século, basta observar que a população de São Paulo, em 1872, era de 31.385 habitantes, passando a 130 mil habitantes em 1895 (dos quais 71 mil eram estrangeiros) e chegando a 239.820 em 1900. (REIS, 2004, p.141)

A ocupação do espaço urbano registrou essas transformações. Nesse período, a área urbana se expandiu para além do perímetro do "triângulo", com a consolidação de uma infinidade de novos loteamentos; surgiram as primeiras linhas de bondes, os reservatórios de água e a iluminação a gás. Esses fatores somados já esboçavam a formação de um parque industrial paulistano.

A partir do final do século XIX, as elites representativas da burguesia urbana, em plena formação, deram preferência para os bairros de além-Anhangabaú e iniciou-se o processo de crescente segregação das camadas de alta renda em bairros exclusivos, inicialmente, em direção a oeste, envolvendo os Campos Elíseos, Vila Buarque, Santa Cecília e Higienópolis e, depois, desviando-se e projetando-se em direção à avenida Paulista, para Cerqueira César e, mais tarde, para os bairros Jardins e Pacaembu (ROLNIK, 1997: p46). Por outro lado e simultaneamente, locais como Glória, Carmo e Liberdade começaram a ser ocupados por camadas de renda mais baixa e bairros operários se formaram nas zonas industriais, em direção às várzeas, onde haviam sido instaladas as ferrovias, como Mooca, Brás, Pari, Belém, Lapa, Bom Retiro, Ipiranga. (VILLAÇA, 1998, p.263).

A construção do Viaduto do Chá ${ }^{33}$, em 1891, permitiu o cruzamento do Vale do Anhangabaú e deu nova configuração a São Paulo, ligando um lado tradicional da cidade a outro, que rapidamente surgia (VILLAÇA, 1998). Os fluxos de tráfego provenientes dos bairros aristocráticos penetravam no Triângulo através da rua Direita, que, aos poucos, foi se

\footnotetext{
${ }^{33}$ A Companhia Ferrocarril, responsável pela utilização do viaduto, cobrava três vinténs de pedágio para passar para o outro lado, sobre o Rio Anhangabaú. A cidade cresceu e a estrutura de metal com assoalho de madeira não suportava o trânsito de pessoas, de cabriolés e de carroças. Em 1938, foi demolido e substituído por um de concreto armado e com o dobro de largura.
} 
tornando comercialmente mais atrativa que a rua Quinze de Novembro. No início do século $\mathrm{XX}$, passou a ser a principal rua de comércio e serviços da burguesia, nela se localizando as grandes lojas da época, bem mais sofisticadas, instaladas em prédios especialmente construídos, como a Casa Alemã (depois, Galeria Paulista de Modas), o Mappin Store, que da rua XV de Novembro mudou-se para a Praça do Patriarca, em 1919, a Casa Au Bon Marché e a Casa Sloper, voltadas para a elite, dentre outras que mantiveram longamente a tradição comercial da rua.

A tradição da elite da rua Direita ocupou aproximadamente as três primeiras décadas do século XX, quando a preferência passou para a rua Barão de Itapetininga, no outro extremo do viaduto, que se transformou no novo centro comercial desta camada da população.

Nesta época, instala-se na rua Direita, a Lojas Americanas, conhecida como "Casa dos Dois Mil Réis" ${ }^{34}$, primeira de um estilo diferente para os padrões da época, com muita variedade de mercadorias baratas - nada custava mais do que dois mil-réis ${ }^{35}$ - destinadas ao consumo da nascente classe média.

No final dos anos 50, o centro de São Paulo estava claramente dividido pelo Vale do Anhangabaú e passou a ter dois centros, o Velho e o Novo. Na parte voltada para sudoeste, além do Anhangabaú, tendo por eixo a Barão de Itapetininga, as transversais e a rua do Arouche, localizavam-se os escritórios de profissionais liberais, o comércio de luxo, os cinemas e os restaurantes dirigidos às classes de renda mais alta, constituindo-se no se chamou de "Centro Novo". Para o lado de cá do vale, o antigo centro, o "Centro Velho", que

\footnotetext{
${ }^{34}$ A Lojas Americanas veio para o Brasil no ano de 1929, com o objetivo de lançar uma loja com preços baixos, no modelo que já fazia sucesso nos Estados Unidos e na Europa, no início do século, no estilo Five and Ten Cents (lojas que vendiam mercadorias a 5 e 10 centavos, na moeda americana). O nome "Dois mil Reis" deve-se ao slogan "Nada além de 2 mil réis". A palavra "Loja", no nome da empresa, foi uma novidade que designava um novo estilo de vendas, diferente dos estabelecimentos da época, denominados "casa". Fonte: Histórico da empresa, disponível em http://ri.lasa.com.br, acesso em novembro de 2005.

${ }^{35}$ Este tipo de loja e varejo assemelha-se às "Lojas de R $\$ 1,99$ " dos tempos atuais (que começaram como lojas de $\mathrm{R} \$ 1,00$, logo depois do fim da URV, em 1994).
} 
mantivera vinculação com as camadas de mais alta renda, ressentiu-se dessa deflexão, que fez com que as ruas do "triângulo" começassem a se desvalorizar e suas lojas se “popularizassem”. Nas ruas Quinze de Novembro e Boa Vista as casas comerciais foram desaparecendo para dar lugar às instituições financeiras e bancárias, bem como escritórios de advocacia, tabeliões, que, ainda hoje, têm ali uma área de concentração significativa.

Nos anos seguintes, a preocupação com o espaço urbano visava, basicamente, abrir caminho para os automóveis e atender aos interesses da indústria automobilística, que se instalou em São Paulo, em 1956. A motorização da população, que ocasionou crescente congestionamento do centro, também permitiu a mobilidade e o deslocamento para áreas mais distantes e, consequentemente, os comerciantes começaram a descobrir as conveniências de se estabelecerem fora do centro. (LIMA FILHO, 1975; VARGAS, 2001)

A partir dos anos sessenta inicia-se um novo processo de mudança de localização das atividades de comércio e serviços. Em meio ao crescente ritmo da industrialização, o aumento do uso do automóvel e, confirmando o vetor de expansão urbana em direção sudoeste, com a cidade, abrigando 3,8 milhões de habitantes, surge um novo núcleo comercial formado pela avenida Paulista e rua Augusta. Para Villaça (1998) este núcleo seria o "novo" Centro de São Paulo. Villaça registra, com clareza, a diferença existente entre este chamado "novo" Centro e as transformações ocorridas anteriormente:

“O dito 'novo' Centro principal da cidade é diferente do anterior, representado pela área da rua Barão de Itapetininga, pois não reproduzia, como ele, uma nova versão do Centro velho; era um novo tipo de centro, atomizado, fragmentado, expandido e constituído por uma nuvem de áreas especializadas, misturado com vários tipos de áreas residenciais" (VILLAÇA, 1998, p. 265).

O Centro que surgia, continua Villaça, era especializado: a avenida Paulista, em cinemas, escritórios e bancos e a rua Augusta, em butiques, lojas de vestuário, calçados, eletrodomésticos, roupa de cama, mesa e banho. O Centro antigo era compacto e o Centro novo era disperso e o crescimento posterior, à medida que se diversificava, começou a formar 
o chamado "Centro Expandido"36, espalhado por uma enorme região mesclada com residências individuais ou em apartamentos, escritórios, hotéis e restaurantes.

O Centro "novo" também foi abandonado pelas camadas de alta renda, passando a ser ocupado pelas camadas populares e se agregou ao antigo formando um único Centro Velho (VILLAÇA, 1998, p.265), que, aos poucos, deixava de ser o pólo cultural freqüentado pela classe alta e não era mais alvo principal dos investimentos.

A rua Augusta, na década de 60, através de suas lojas, tornou-se o ponto de compras mais sofisticado da cidade. Uma vez localizada no meio dos bairros dos Jardins, de classe média e alta, tornou-se o grande centro abastecedor da região e o ponto de atração, inclusive, de consumidores de toda a cidade de São Paulo.

Em 1966, é inaugurado o Shopping Center Iguatemi, que, apesar da demora de alguns anos para que a população se acostumasse com o novo comércio (MASANO, 1993, p.103) ocsionou, a partir da década de 70, o começo do processo de decadência comercial da rua Augusta, que se desvalorizou, mas não se popularizou como as ruas do centro tradicional. Isto porque, não houve o deslocamento da classe alta para outras regiões como o que se verificou no centro histórico. O esvaziamento da rua Augusta deveu-se, primeiramente e início dos nos setenta, à mudança de hábito de consumo introduzida pelos shoppings, e, depois, por volta dos anos oitenta, quando a região recuperou seu prestígio, mas o aumento excessivo nos aluguéis dos seus imóveis e a incompatibilidade das características físicas de suas lojas com novos requisitos exigidos especialmente quanto área de venda mais amplas, pé-direito duplo, estacionamento fácil, deu oportunidade à ocupação dos sobrados das ruas transversais e paralelas, como a rua Oscar Freire, a Alameda Lorena, dentre outras. Estas, com o decorrer do

\footnotetext{
${ }^{36}$ A delimitação dessa área é altamente complexa, podendo-se envolver a região da avenida Faria Lima, da marginal do Rio Pinheiros e avenida Luis Carlos Berrini (Villaça, p.266) não havendo pretensão de realizar aqui tal tarefa. NOBRE (2000) desenvolve estudo específico para região, onde é possível obter maiores detalhes.
} 
tempo assumiriam a condição de ruas especializadas no de comércio de luxo. No ano 2005, a rua Oscar Freire englobando arredores, foi colocada em oitavo lugar, na lista das mais chiques do mundo pelo estudo da Excellence Mystery Shopping International ${ }^{37}$. A rua Serrano, em Madri, na Espanha, foi considerada a mais luxuosa, pelos critérios da pesquisa. A Quinta Avenida, em Nova York, EUA, a Avenida Champs-Élysées, em Paris, França, e a Via Montenapoleone, em Milão, Itália, vêm em segundo, terceiro e quarto lugares, respectivamente.
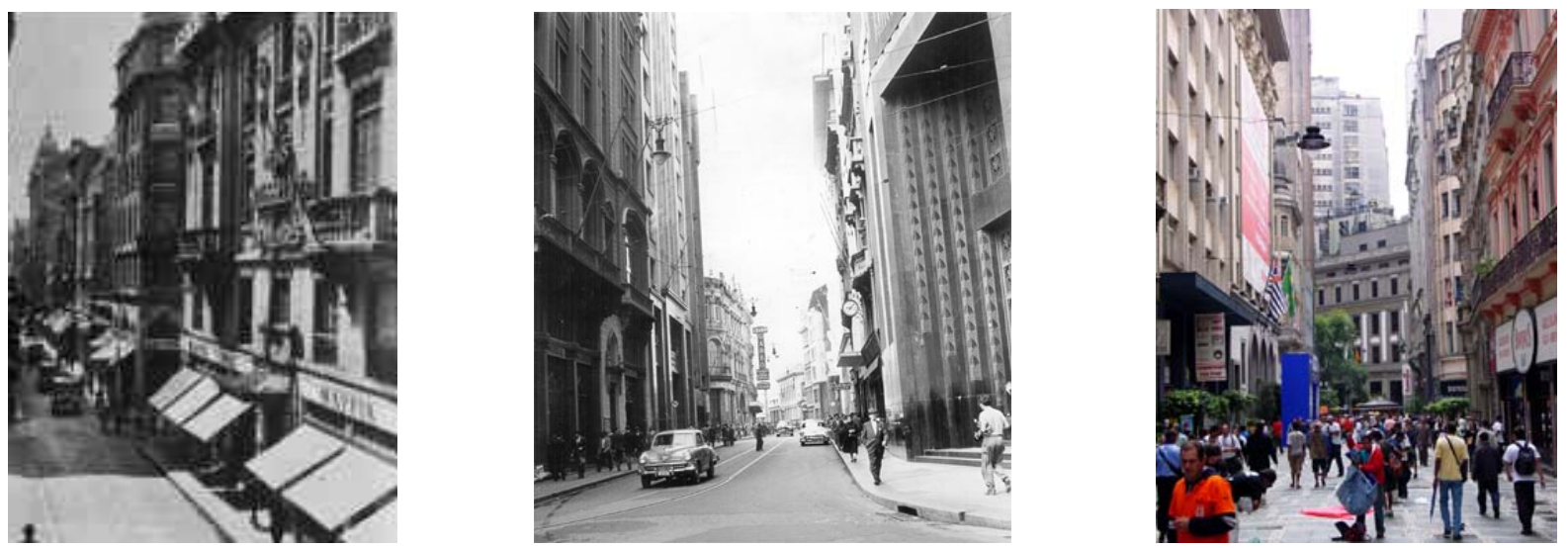

Foto 2.1: Rua XV de Novembro em 1913

Fonte: Memórias do Comércio http://www.museudapessoa.net/biblioteca/index.htm

Foto 2.2: Rua XV de Novembro em 1965

Fonte: Folha imagem $<$ http://almanaque.folha.uol.com.br/saopaulo>, fev.2006.

Foto 2.3: Rua XV de Novembro em 2006

Fonte: Autora, março, 2006.
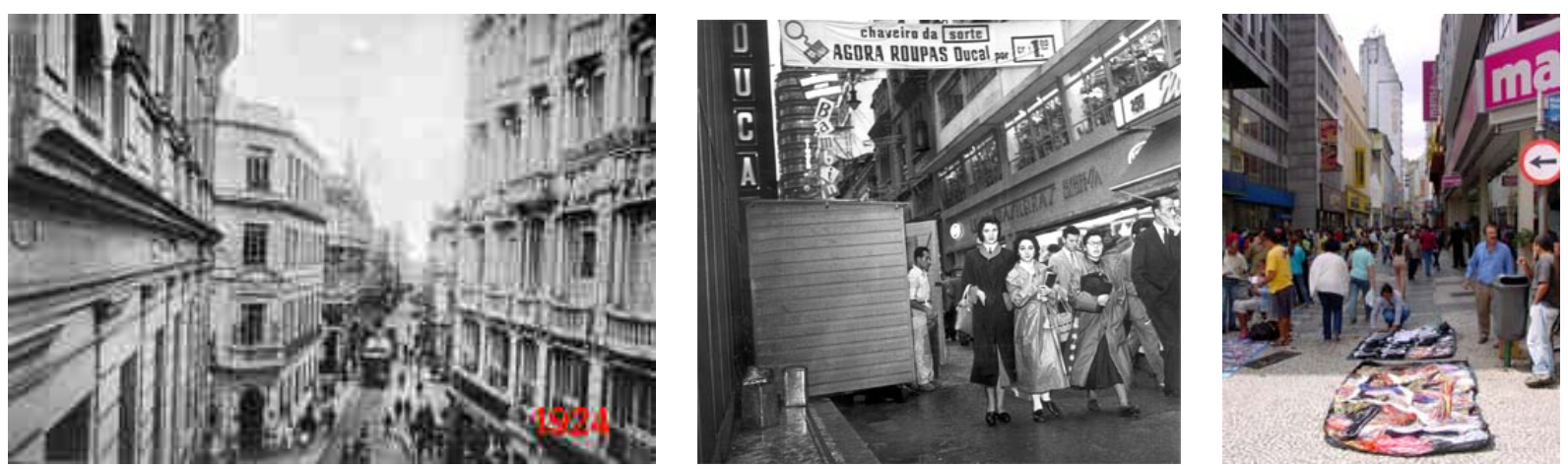

Foto 2.4: Rua Direita em 1924

Fonte: Memórias do Comércio <http://www.museudapessoa.net/biblioteca/index.htm>

Foto 2.5: Rua Direita em 1957

Fonte: Folha imagem< http://almanaque.folha.uol.com.br/saopaulo>, fev.2006

Foto 2.6: Rua Direita em 2006

Fonte: Autora, março, 2006

${ }^{37}$ Fonte: $<$ http://www.excellencemysteryshopping.com/News_us.asp > acesso em janeiro de 2006. 

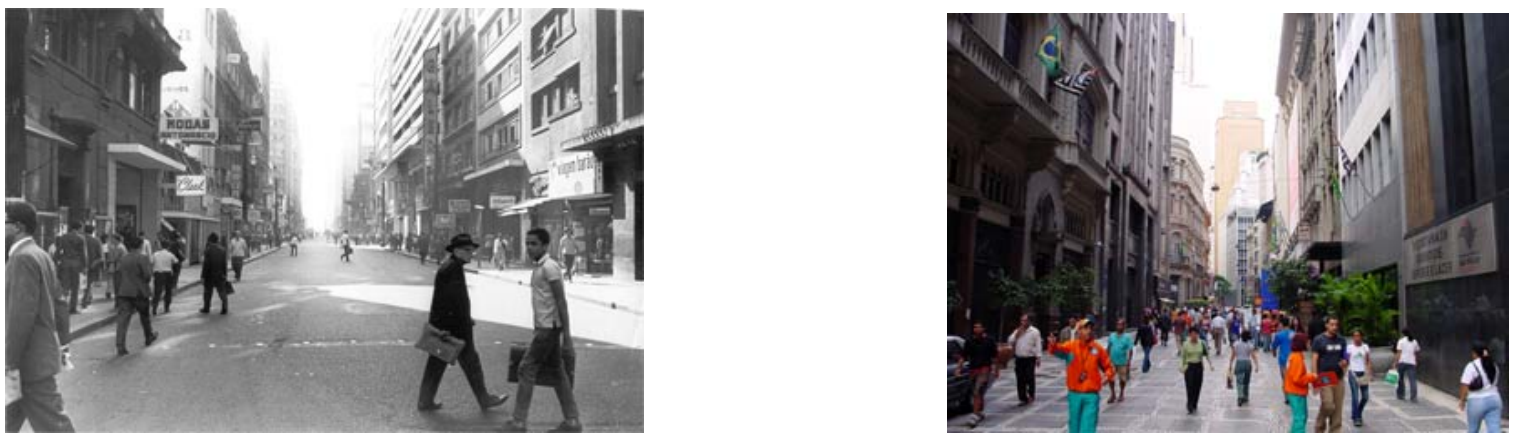

Foto 2.7: Rua Barão de Itapetininga em 1957

Fonte: Folha imagem< http://almanaque.folha.uol.com.br/saopaulo $>$, fev.2006

Foto 2.8: Rua Barão de Itapetininga em 2006

Fonte: Autora, março, 2006.
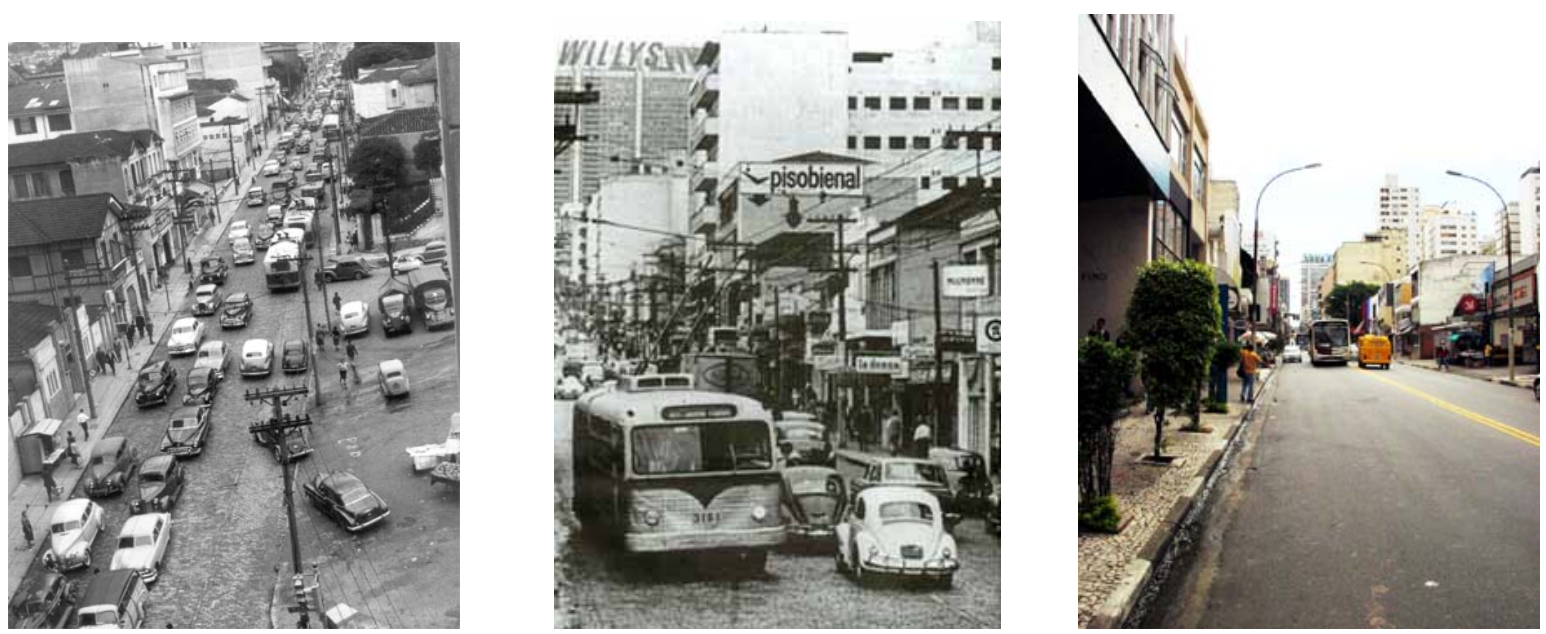

Foto 2.9: Rua Augusta em 1960

Fonte: Folha imagem< http://fotos.terra.com.br/album.cgi $/ * 477998: 0>$, fev.2006

Foto 2.10: Rua Augusta em 1960

Fonte: Folha imagem $<$ http://almanaque.folha.uol.com.br/saopaulo $>$, fev.2006

Foto 2.11: Rua Augusta em 2006

Fonte: Autora, março, 2006
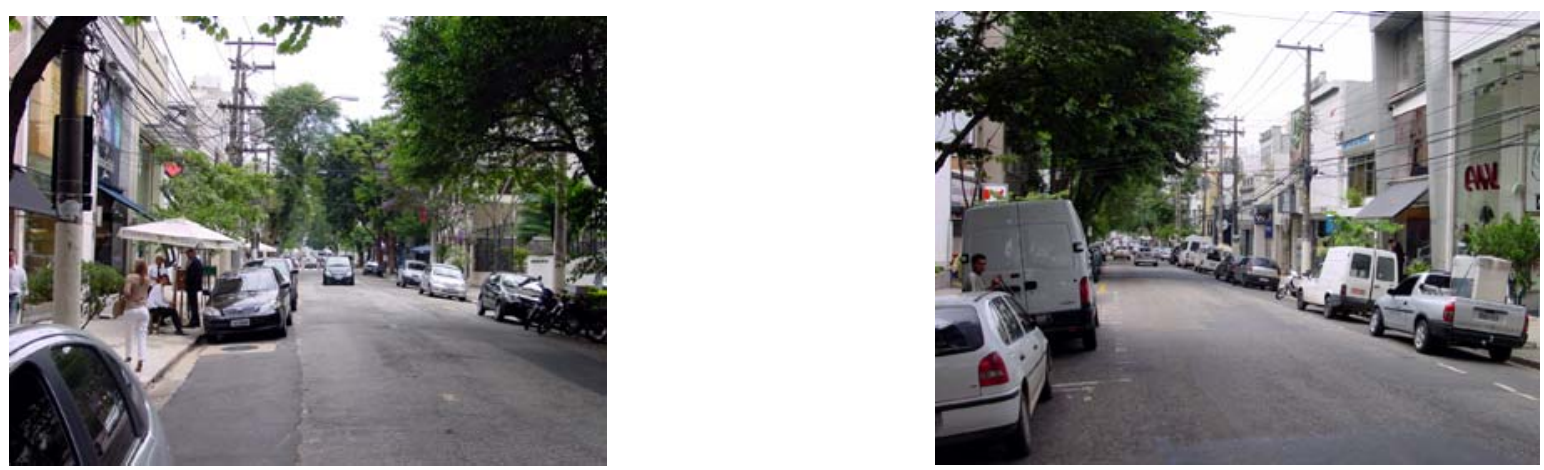

Foto 2.12: Rua Oscar Freire em 2006

Fonte: Autora, março, 2006

Foto 2.13: Rua Oscar Freire em 2006

Fonte: Autora, março, 2006 


\subsection{1 -Comércio regional de bairro ou subcentro comercial}

A ocupação dos espaços urbanos foi ocorrendo com a riqueza produzida pelo café e, em seguida, com o início da industrialização. Ao mesmo tempo em que surgiam novos bairros, que atendiam à emergente elite dos fazendeiros, e o comércio tradicional crescia e acompanhava o seu deslocamento, surgiam, simultaneamente, bairros populares destinados à classe trabalhadora, ao longo dos quais se desenvolviam subcentros comerciais populares.

Os bairros tradicionais, como Brás (zona Leste), Pinheiros (zona Sudoeste), Lapa (zona Noroeste), Santana (Zona Norte) e Santo Amaro (Zona Sul), tiveram em comum a concentração do comércio, com uma tendência espontânea de se localizar em pontos estratégicos, que, de alguma forma, condensavam o fluxo de pessoas, tais como em interseções de transporte coletivo, constituindo-se, conforme definido no capítulo 1, a rua comercial de bairro, ou, como identifica Villaça (1998), os subcentros comerciais de comércio e serviços populares.

O primeiro subcentro a surgir na cidade de São Paulo foi o Brás, que, já na década de 1920, podia ser considerado um centro comercial independente, de notória expressão. Isso se deve ao fato de sua população, constituída em grande parte por imigrantes italianos, não ter acesso econômico e social ao centro, condições que contribuíram para que o bairro desenvolvesse uma grande demanda para comércio e serviços e se constituísse no primeiro subcentro comercial da cidade de São Paulo. Grandes lojas - as maiores de São Paulo - tiveram seu início no Brás, como "Pirani”, "Eletroradiobrás", "Lojas de Móveis Brasil” e tantas outras (VILLAÇA, 1998, p. 297; MASANO, 1993, p.102).

Os demais subcentros populares de São Paulo, inclusive alguns centros principais de municípios da região metropolitana, como Santo André e São Caetano, começaram a se desenvolver na década de 1940, quando começaram a abrigar, generalizadamente, filiais de 
bancos e lojas existentes no centro (Villaça, p. 300). Em São Paulo, pode-se encontrar mais de uma dezena de zonas comerciais de bairro, que ainda mantêm as características de comércio popular e que, geralmente, são identificadas pelo nome de uma rua específica, podendo ser citadas como as mais tradicionais: Santana (rua Voluntários da Pátria), Santo Amaro (Largo Treze), Pinheiros (rua Teodoro Sampaio), Lapa (rua Doze de Outubro).

A necessidade de um comércio varejista não muito distante e de fácil acesso faz com que surjam, também, aglomerados varejistas menores, formados por um pequeno complexo de lojas direcionadas para a comercialização de produtos de conveniência, como: farmácias, padarias, quitandas, açougues e prestadores de serviço, constituindo-se nas ruas comerciais de vizinhança, conceituadas no capítulo 1. Estão distribuídas em diversos pontos da cidade e se mantêm como comércio local, mas não alcançam o desenvolvimento dos mencionados subcentros tradicionais.

De acordo com Villaça (1998, p. 276), “o surgimento de subcentros voltados para as camadas de baixa renda, entre as décadas de 20 e 40, não teve impacto na vitalidade do centro principal, apesar do desenvolvimento de subcentros de grande porte, porém populares, como Brás, Lapa ou Pinheiros, pois, em 1950, o centro ainda mantinha grande vitalidade orientada para a camada de alta renda” e, continua Villaça, "não havia - e ainda não há - subcentros voltados para a classe de renda mais alta e zonas comerciais como a região da rua Augusta ou da João Cachoeira (Itaim), por exemplo, não são subcentros”.

\subsubsection{Ruas de comércio especializado}

A partir de 1952, ao mesmo tempo em que o comércio e serviços de elite começaram a abandonar o centro tradicional, deslocando-se para a região da rua Augusta, e cresciam os subcentros de comércio e serviços populares, um cinturão de comércio especializado se estendeu no entorno do Centro de São Paulo, criando uma dimensão própria para o comércio 
varejista e atacadista, definindo um outro perfil para a dinâmica comercial da cidade. (AB'SABER, 2004, p140). Segundo este autor, a degradação em função do descarte da área central histórica foi "compensada" por uma concentração setorizada de funções comerciais específicas, concentração essa que deu origem às ruas especializadas em um tipo de produto.

Embora seja difícil precisar as datas, argumenta AB'SABER, um comércio de lustres e luminárias dominou a rua da Consolação nos interstícios entre Higienópolis, Augusta e Cerqueira Cesar em 1955, enquanto que a rua São Caetano começa a ficar conhecida como a "rua da Noivas"com lojas especializadas em vestidos e acessórios para noivas em 1960. Na mesma década de 60, a rua Teodoro Sampaio, em Pinheiros, começou a se destacar para móveis e objetos de decoração Santa Efigênia se insere neste quadro, com seu comércio centrado em equipamentos elétricos e eletrônicos.

Estas ruas atraem grande fluxo de consumidores e têm mantido a vitalidade comercial ao longo dos anos, sendo que outras vêm surgindo, sempre espontaneamente, pela atração de produtos específicos.

A Alameda Gabriel Monteiro da Silva, que corta os bairros do Jardim Paulistano e Jardim Europa, ficou famosa nos anos 80, com a instalação de uma variedade de lojas de decoração de alto padrão. Ultimamente vem sofrendo com a legislação municipal, que alega que a região é estritamente residencial e os imóveis comerciais são proibidos. Antes da instituição das leis de zoneamento, entretanto, essa alameda já estava tomada pelas lojas. O shopping D\&Dtemático em design e decoração, compôs parte do seu mix de lojas, com algumas filiais oriundas da Alameda Gabriel Monteiro da Silva.

As avenidas Europa/Colombia especializaram-se em showrooms de carros importados. A Avenida Rebouças, no passado uma artéria residencial, aos poucos foi se transformando em corredor de comércio diversificado e, atualmente, verificam-se alguns bolsões de 
agrupamentos, como, por exemplo, as lojas especializadas em vestidos de noivas e aluguel de roupas. (AB'SABER, 2004, p141).

A concentração de comércio específico e que deu origem às ruas especializadas da região central, atualmente é um fenômeno que se expandiu para diversos pontos da cidade, podendo ser citadas, como exemplo, áreas de escritórios de profissionais liberais como a rua Itapeva (médicos) e áreas de numerosos centros biomédicos, como a avenida Brasil, nos Jardins, a rua Brigadeiro Gavião Peixoto, na Lapa, entre outras.

\begin{tabular}{l|l}
\hline \multicolumn{1}{c|}{ Rua/Bairro } & \multicolumn{1}{c}{ Especialidade } \\
\hline Av. Duque de Caxias - Centro & Autopeças e Acessórios para automóveis \\
\hline Av. São Luís - Centro & Agências de viagem \\
\hline Rua 25 de Março - Centro & Tecidos/ Armarinhos/ Artigos diversos \\
\hline Largo do Arouche - Centro & Flores \\
\hline Rua Dr. Arnaldo - Pinheiros & Material fotográfico \\
\hline Rua Conselheiro Crispiniano - Centro & Ferramentas e máquinas \\
\hline Rua Florêncio de Abreu - Centro & Enxovais / Cama-mesa e banho \\
\hline Rua Oriente/Maria Marcolina - Brás & lluminação \\
\hline Rua da Consolação - Consolação & Vestuário (atacado e varejo) \\
\hline Rua José Paulino - Bom Retiro & Motos e motopeças \\
\hline Rua Barão de Limeira -Campos Elíseos & Produtos orientais \\
\hline Rua Galvão Bueno - Liberdade & Utensílios para bares e cozinhas industriais \\
\hline Rua Paula Souza - Luz & Uniformes \\
\hline Av. Tiradentes - Luz & Vestidos de noivas \\
\hline Rua São Caetano - Luz & Eletroeletrônicos \\
\hline Rua Santa Efigênia -Santa Efigênia & Artigos para pinturas artísticas \\
\hline Rua Marquês de Itu - Vila Buarque & Madeiras e ferragens para marcenaria \\
\hline Rua do Gasômetro - Brás & Móveis/Instrumentos musicais \\
\hline Rua Paes Leme - Pinheiros & Decorações (objetos, materiais) \\
\hline Al. Gabriel Monteiro da Silva -Jardins & Automóveis importados \\
\hline Av. Europa - Jd. América & \\
\hline &
\end{tabular}

Tabela 2.1 - Principais ruas especializadas na cidade de São Paulo Fonte: Autora, base Prefeitura Municipal de São Paulo e Associação Viva o Centro 


\subsection{3 - Galerias comerciais}

Os edifícios e as galerias comerciais surgem nas décadas de 50 e 60, de um forte vínculo entre a função comercial e a verticalização, num contexto de oportunidade, como negócio imobiliário no "Centro Novo", quando havia grande demanda por pontos comerciais no local e poucos terrenos (MEYER, 1991, p. 31). Essas galerias eram pólos da cultura elitista paulistana e abrigavam lojas de alto luxo, alfaiatarias, chapelarias, charutarias, bares e restaurantes, formando ambientes comerciais e pontos de encontro de intelectuais, artistas e boêmios.

Para Vargas (2001, p.278), embora chamadas de galerias, elas, no que se refere ao formato, tipo de empreendimento e razão de ser, diferem significativamente das galerias européias ${ }^{38}$ do século XIX. Com relação ao que se considera como galeria comercial na cidade de São Paulo, de acordo com Meyer (1992), quatro tipos diferentes são identificados: o edifício conjunto, que congrega, no mesmo espaço, múltiplas atividades de comércio, restaurante, escritórios, garagens, ruas internas, residências; o edifício-galeria, com lojas no andar térreo, com características de ruas e permitindo a passagem através delas; o edifício comercial com todos os andares voltados ao uso comercial e de serviços; e passagem, um caminho estreito cruzando as quadras, com lojas de um ou dois lados.

Os dois primeiros tipos de galerias, continua Vargas, começaram a ser construídos ditados por ideais modernistas e pela mentalidade elitizada da classe política e dos urbanistas, especialmente a partir de 1957, quando a construção de galerias na área central acabou por

\footnotetext{
${ }^{38} \mathrm{O}$ conceito de arcadas, passagens ou galerias comerciais, segundo Vargas, é ambíguo, dado que não pertencem, exclusivamente, nem a um espaço privado nem a monumentos públicos. Para referências quanto ao conceito, histórico, difusão e expansão das galerias européias, consultar VARGAS, Heliana Comin (capítulo 3, Arquitetura de Negócios. 2001, pp.93-207).
} 
tornar-se obrigatória nas edificações que possuíssem lotes lindeiros a determinadas ruas ${ }^{39}$, sendo possível imaginar que, desde então, muitas das galerias nasceram da exigência da legislação urbanística. Nesses tipos de galerias nem sempre as premissas do desenvolvimento varejista, sua lógica espacial, seu mix foram levados em consideração, ocasionando permanentes desinteresses comerciais e desocupação permanente de área de lojas.

A Galeria Nova Barão (na rua Barão de Itapetininga e rua Sete de Abril) argumenta VARGAS, por outro lado, é um claro exemplo de aumento de áreas comerciais adotando princípios de empreendimento imobiliário lastreado na atividade varejista: rompe o interior da quadra criando uma nova rua, para onde se abrem prédios de apartamentos e escritórios.

As galerias construídas entre o final da década de 40 e os anos 60 passam a incorporar o comércio em mais de um andar, aumentando a circulação interna. "O sucesso das primeiras galerias intensificou investimentos no setor, exigindo um número cada vez maior de lojas nos projetos", descreve ALEIXO (2005, p. 4). "Nesse momento enquadram-se edifícios como as Grandes Galerias e o Centro Comercial Presidente, na rua 24 de Maio”.

Na avenida Paulista também vão aparecer as chamadas galerias, entre as mais significativas é, ainda, o Conjunto Nacional, assim como, na rua Augusta, a Galeria Ouro Fino.

No momento em que o centro de São Paulo passou a assumir um papel diferente diante da metrópole, deixando aos poucos de ser o pólo cultural freqüentado pela classe alta, iniciando o processo de degradação, as galerias comerciais eram abandonadas tanto pelos comerciantes como pelos usuários. Muitas delas, criadas tardiamente, nunca chegaram a experimentar o sucesso e as lojas, quando não ficavam vazias, eram subdivididas, transformando-se em cubículos de um comércio de baixo nível, tanto em termos de adaptação como de

\footnotetext{
${ }^{39}$ Prefeitura do Município de São Paulo, Lei n ${ }^{\circ}$ 4.144/1957: Obriga a construção de galerias nas edificações que se fizerem nos lotes lindeiros às ruas Direita, São Bento, 24 de maio e 7 de Abril e dá outras providências.
} 
lucratividade (VARGAS, 2001, p.283).

Algumas galerias são conhecidas por oferecerem mercadorias diferentes, especializadas e raras, que não podem ser facilmente encontradas em outros lugares. Outras galerias tornaramse "temáticas" como ponto de encontro de tribos urbanas e sede de um comércio diferenciado, como é o caso da "Galeria do Rock" ${ }^{40}$, localizada na rua 24 de Maio, que ocupa o edifício "Grandes Galerias". A Galeria Ouro Fino, na rua Augusta, é um dos casos que teve recuperação mercadológica a partir de um "estilo alternativo" para expositores do Mercado Mundo $\mathrm{Mix}^{41}$.
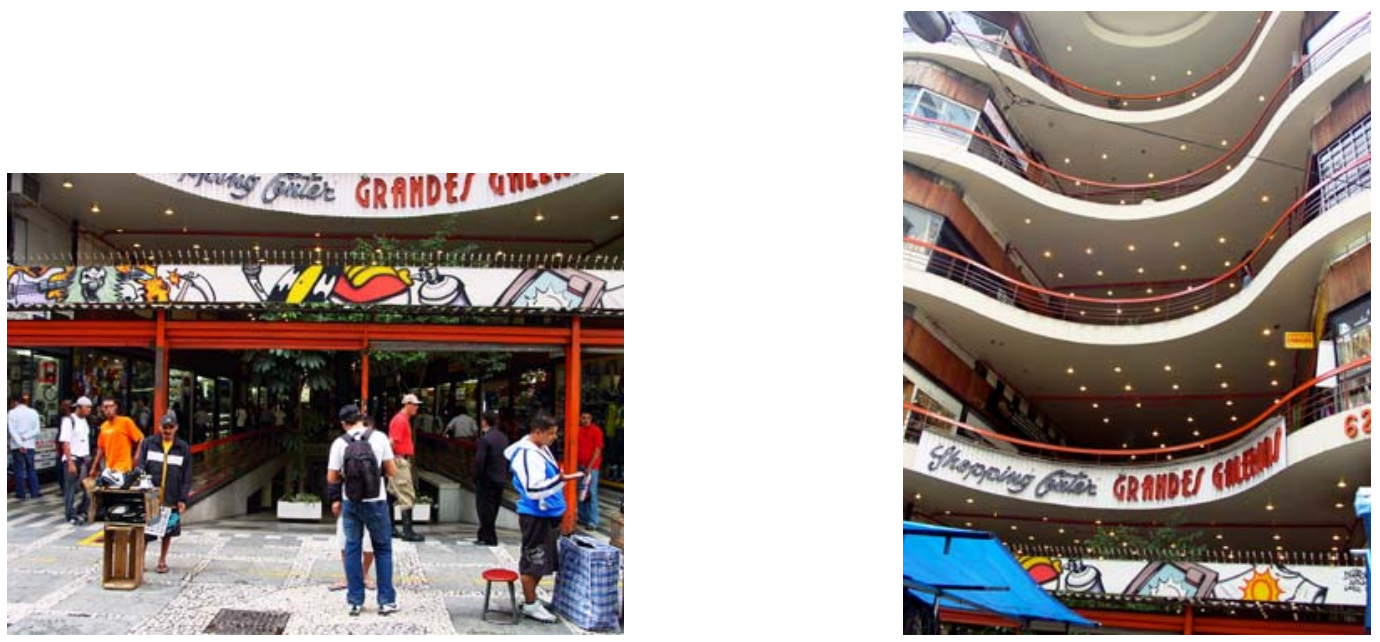

Foto 2.14: Galeria do Rock.

Fonte: Autora, março, 2006

Foto 2.15: Galeria do Rock.

Fonte: Autora, março, 2006

\footnotetext{
${ }^{40}$ O edifício Grandes Galerias, construído em 1963, originalmente abrigava salões de beleza, lojas de serigrafia e assistências técnicas de aparelhos eletroeletrônicos. No final da década de 70, lojas de disco começaram a se instalar no local e, pelo grande número de estabelecimentos voltados para o público que gostava de rock (CDs, discos, vídeos, camisetas e pôsteres) foi apelidado de "Galeria do Rock". A partir de 1980, passou a ser ponto de encontro entre jovens de diversas tribos, como os "metaleiros", "góticos" e "punks" e, nos últimos anos, a cultura de rua, o "Hip Hop", também conquistou seu espaço na Galeria do Rock. Atualmente é ponto de encontro dessas e outras "tribos urbanas" e sede de um comércio exótico e variado.

${ }^{41}$ Quando surgiu, há mais de dez anos, o Mercado Mundo Mix abriu espaço para novos estilistas e designers. Muitas marcas conhecidas, como "Cavalera", "A Mulher do Padre", "Chilli Beans", "Doc Dog", que se transformaram em marcas famosas e até abriram filiais em shopping centers, começaram vendendo no Mercado Mundo Mix.
} 
Usando as conclusões da arquiteta Cyntia Aleixo (2005), e com elas concordando, as galerias se integravam à dinâmica das ruas centrais de São Paulo, usadas por investidores e arquitetos nas décadas de 40 e 60 do século passado para compensar falta de espaço devido à grande demanda por pontos comerciais no centro novo, praticamente exclusivo na função de área comercial de luxo da cidade naquela época. A escala da rua eram vitais para as galerias, que estimulavam ligação destas com cinemas, teatros e praças e, nesse aspecto, suas vitrines eram um cartão transparente da rua (GAMA, 1998, apud ALEIXO, 2005).

\section{2 - Transformações no espaço urbano em função de novos formatos varejistas}

A mudança do padrão de industrialização na cidade e de seu mercado consumidor somou-se à maior variedade de produtos, favorecendo a assimilação de novos costumes, produtos, técnicas de venda e novas necessidades. Essa situação singular fez crescer o comércio varejista e introduziu profundas transformações no comércio atacadista e importador, além de fazer surgir novos tipos de estabelecimentos, que desenvolveram novos métodos e criaram novos hábitos de consumo. A ocupação do espaço urbano registrou essas transformações.

No Brasil, as transformações no comércio se intensificam após a II Guerra Mundial, com a consolidação e expansão da industrialização do território, principalmente pela indústria automobilística, eletroeletrônica e de bens de consumo não duráveis. A industrialização acelerou o processo de urbanização, particularmente a partir da década de 1960 . O comércio passou a introduzir novas formas para a reprodução do capital, sendo os principais fatores "[...] a produção em massa, concentração crescente de pessoas nas cidades, aumento qualitativo e quantitativo do consumo e a generalização do uso do automóvel". (PINTAUDI, 1989, p.82). Estes fatores foram primordiais para a realização do lucro e para a consolidação de novas formas e de novos padrões de localização do comércio nas cidades. 
Dentre as formas que o comércio passou a introduzir no espaço urbano, merecem destaque, neste trabalho, pelas especificidades e o impacto direto nas transformações do comércio tradicional, as lojas de departamentos, os supermercados e os hipermercados e os shopping centers.

\subsection{1 - Lojas de departamentos}

Há registros $^{42}$ de que a primeira loja de departamentos do mundo tenha sido o estabelecimento $\mathrm{Au}$ Bon Marché, inaugurado em Paris, em 1852, pioneira na técnica de agrupamento dos produtos em categorias, introduzindo um novo sistema de organização de vendas a varejo. Não se tratava de uma loja muito maior, mas com um novo conceito de vender e consumir, abandonando as antigas práticas de consumo por outras novas, baseadas nos princípios de variedade de artigos em todos os ramos; pequena margem de lucro em cada item (tendo como compensação grande volume de mercadorias vendidas); preços fixos e claramente marcados (de forma que qualquer um podia entrar na loja apenas para olhar, sem comprar); pagamentos à vista e permissão de trocas, diferentemente do que se praticava nos estabelecimentos tradicionais, onde entrar na loja representava um contrato implícito de compra.

Porém, relembram Morgado e Gonçalves (1997, p.56), apesar de os franceses terem iniciado o negócio de lojas de departamentos, os inovadores foram os americanos, sendo o Palácio de Mármore dos Tecidos e Novidades, em Nova York, o pioneiro, em 1846.

No início da atividade comercial, o abastecimento se dava por um tipo de estabelecimento comercial, denominado Loja Geral, "General Store”, onde era possível encontrar desde alimentos e roupas até implementos agrícolas. Ao contrário da loja de departamentos - sua

\footnotetext{
${ }^{42}$ Para ler mais sobre o assunto, ver SIMÕES, Roberto. "Dos fenícios aos hipermercados”. Marketing. Ano 13, n. 79, junho, 1980; e “Iniciação ao marketing”. 4. ed. Atlas, São Paulo: 1986.
} 
sucessora -, era operada pelo próprio dono e sua família e não apresentava qualquer estruturação operacional interna.

A Lojas Garraux, aberta em 1860, na rua XV de Novembro (ainda rua da Imperatriz), num prédio com ampla fachada de mármore, porta central e duas grandes vitrinas laterais, foi uma das grandes lojas gerais da época; teoricamente era uma papelaria, mas vendia tudo: livros, objetos de escritório, feijão, arroz, batatas, finos vinhos franceses (BRUNO, Silva, 1954, pp.1162-1163; apud VILLAÇA, 1998, p. 262).

De acordo com Alvim e Peirão (1985 p. 33; apud VARGAS, 2001, p.271), a cidade de São Paulo recebeu a primeira loja de departamentos em 1913, a Mappin Stores, filial da inglesa Mappin \& Web, instalada na rua XV de Novembro, no "triângulo" comercial. Em 1919, a rua $\mathrm{XV}$ de Novembro perdeu suas características comerciais ao mesmo tempo em que se tornava o centro financeiro de São Paulo e o Mappin mudou-se para onde é hoje a Praça do Patriarca, instalando-se em uma aristocrática mansão da época, a Casa Barão de Iguape. As vitrines passaram a compor o andar térreo, inaugurando uma novidade para o comércio paulistano que, até então, empilhava mercadorias na entrada das lojas como forma de exposição. A cidade mudava e o Mappin mudou-se de novo, no ano de 1939, para a rua Barão de Itapetininga, que despontava para o comércio da elite, atravessando, portanto, o vale do Anhangabaú e posicionado-se em frente ao Teatro Municipal de São Paulo. Segundo Alvim e Peirão, a mudança foi muito significativa, pois funcionou como um forte indutor da urbanização, levando atrás de si uma série de outros estabelecimentos comerciais (VARGAS, 2001 p. 275).

Com a crise do café, que abalou a economia de São Paulo no início da década de 30, e a concorrência das lojas de descontos e de magazines populares como "A Exposição" e "A Capital", o Mappin foi obrigado a se adaptar. Como estratégia para atrair público popular, 
colocou etiquetas com preços nos produtos em suas vitrinas, numa atitude ousada. $\mathrm{O}$ tradicional salão de chá, a barbearia, entre outras seções, cederiam lugar para exposição e venda de artigos fabricados pela indústria nacional por meio de um sistema de financiamento criado em 1952 e oferecendo aos clientes a possibilidade de fazer suas compras a prazo, num sistema de crediário, do qual foi o precursor.

Morgado e Gonçalves (1997, p.59) esclarecem que, apesar da existência de estabelecimentos comerciais de grande porte, instalados na virada do século XX - como as Casas Pernambucanas, em 1906 e a Mesbla, em 1912, no Rio de Janeiro, e o Mappin Stores consideram a "Sears, Roeduck and Company", fundada em 1949, um dos marcos da modernização do varejo brasileiro, quando implantou sua loja a aproximadamente quatro quilômetros de distância do centro da cidade.

Na mesma linha de raciocínio, porém mais focado na questão urbana, Lima Filho (1975, p.43) acrescenta que, ao operar fora da zona Central de São Paulo, a Sears introduz uma excepcional mudança no tradicional padrão de localização do comércio varejista. Naquele momento, esclarece o autor, as instituições varejistas cresceram em função da necessidade de se ajustar e melhorar o sistema de abastecimento, a qual se tornou evidente pela expansão industrial e explosão urbana, após a Segunda Guerra Mundial. A decisão da Sears de se localizar distante do centro foi importante para o movimento de descentralização decorrente do aumento do número de automóveis, congestionamento de trânsito e alterações nos hábitos de compra em termos de preferência de local. Seu raio de atração não é o limite de um bairro, mas todo o perímetro urbano.

A loja de departamentos, antes mesmo do shopping center, indicou uma transformação no sentido da rua de comércio, já que conseguia reunir, num único local, grande variedade de 
produtos, abrindo caminho para a tendência de grandes locais comerciais a converterem-se em alternativas independentes dos centros urbanos.

Tradicionalmente, as lojas de departamento ofereciam uma linha completa de produtos. $\mathrm{O}$ Mappin, a Sears, a Sloper, as Lojas Brasileiras e a Mesbla foram exemplos clássicos deste formato de loja, mas não conseguiram sobreviver. Atualmente, não existe esse tipo de loja em São Paulo, que foi substituída por um novo conceito de loja de departamentos, de linha limitada e especializada em determinados segmentos de produtos, como por exemplo, a Renner, a C\&A, a Riachuelo, a Pernambucanas, especializadas em confecções; a Casas Bahia, especializada em móveis e eletrodomésticos.

\subsection{2 - Supermercados e Hipermercados}

Morgado e Gonçalves (1997, p.43) relatam o surgimento, por volta de 1912, no Sul da Califórnia, de um novo formato de varejo, com atendimento por auto-serviço, o "cash and carry" ou "pague e leve"; sendo a Great Atlantic and Pacific Tea Company considerada como, talvez, a primeira rede de lojas de mercearia do mundo. Somente em 1930, mais de uma década e meia depois, foi fundado o primeiro supermercado, em Long Island, New York, o King Kullen, com características que prevalecem até hoje. O supermercado surgiu como produto da evolução do sistema de comercialização por auto-serviço, sendo que um dos maiores motivadores do desenvolvimento do auto-serviço de alimentos foi, sem dúvida, a Grande Depressão, entre o fim da década de 20 e início da de 30, que trouxe a necessidade de preços baixos. As primeiras experiências em auto-serviço ${ }^{43}$, no Brasil, foram implantadas em lojas especializadas, como é o caso do Frigorífico Wilson, que, em 1947, pioneiro no acondicionamento de carnes frescas, implantou este esquema na venda de embutidos.

\footnotetext{
43 Pelo auto-serviço, os consumidores têm contato direto com as mercadorias, sem a necessidade da intermediação de um vendedor.
} 
Entretanto, o emprego dos novos costumes e técnicas de vendas varejistas resultou no fracasso das primeiras experiências realizadas com o Depósito Popular e Supermercado Americano - numa época anterior a 1953, data da instalação do primeiro supermercado, o "Sirva-se" - uma vez que o consumidor acostumado a comprar em feiras livres não estava preparado para aceitar o sistema de auto-serviço. (BRUNA, 1972, p.227).

Paulatinamente, os novos hábitos de consumo trazidos pelas vendas em supermercados foram ganhando preferência pelo público a partir de 1960. Devido ao gradual crescimento de suas atividades, o supermercado adquire dimensões de atuação cada vez maiores, vindo a constituir o que se conhece hoje por hipermercado ${ }^{44}$ (BRUNA,1972, p.227)

A segunda metade de década de 90 foi marcada por grandes mudanças no setor de supermercados no Brasil, devido à abertura e a estabilização da economia. Até 1995, com o mercado bastante restrito, basicamente limitado ao mercado interno e a inflação elevada, observou-se que os supermercados ganhavam mais no mercado financeiro com a compra a prazo e a venda à vista do que com o comércio. Além disso, a inflação dificultava as comparações e o planejamento de compras pelos consumidores. Após 1995, observa-se o crescimento da lucratividade do setor, acompanhado por um intenso processo de internacionalização e pela expansão de cadeias varejistas existentes (SEBRAE/SP, 2004)

Um modelo que começa a ser seguido, embora ainda parcialmente, por alguns supermercados de porte pequeno, é o das chamadas lojas de vizinhança. Este tipo de ponto de venda começa a ocupar o espaço dos supermercados de porte médio: em 1994, 87\% das lojas de autoatendimento eram de pequeno porte e respondiam por $31 \%$ das vendas em reais. Em 2000,

\footnotetext{
${ }^{44} \mathrm{O}$ hipermercado (hypermarché, do francês) oferece produtos variados, alimentos, roupas, móveis, flores e, ainda, dentro de sua estrutura, lanchonetes, facilitando as compras, recreação e, para alguns, o lazer. Fonte: Associação Brasileira de Supermercados (ABRAS).
} 
elas já somavam $91 \%$ do total de lojas e representavam $34 \%$ das vendas (The Boston Consulting Group, 2002).

No varejo de auto-atendimento, é nítida a tentativa de apropriar-se, neste formato menor, de características dos pontos de venda tradicionais, como padaria, açougue, feira e até serviços, como entrega em domicílio. Apesar disso, o varejo tradicional (que faz vendas pelo sistema de balcão) continua com a vantagem da conveniência de localização e de rápida capacidade de adaptação à demanda do público.

\subsection{3 - Shopping Centers}

Ao mesmo tempo em que a Avenida Paulista sofria uma reestruturação de funções, iniciou-se a construção do primeiro shopping center de São Paulo, o Iguatemi, na rua de mesmo nome, (depois Avenida Faria Lima) no mesmo núcleo do chamado "Centro Expandido". Iniciava-se, assim, o ciclo de implantação de centros comerciais planejados e, daí por diante, desde os anos de 1960, uma década depois do surgimento de supermercados, em substituição aos antigos armazéns e quitandas, a cidade de São Paulo e sua região metropolitana passariam a ter inúmeros shoppings (AB'SABER, 2004, p. 347).

O shopping center é o sucessor da loja de departamentos, que, por sua vez, é a sucessora da loja geral, em meados do século XIX. Têm em comum o fato de basear-se na economia de aglomeração e na variedade de produtos que se complementam (VILLAÇA 1998, p.303). Diferencia-se, entretanto, destas outras duas pelo fato de ser um empreendimento imobiliário planejado, ancorado na atividade de comércio, porém acrescido de espaços para serviços, cultura, lazer e entretenimento.

Enquanto empreendimento comercial planejado, os shopping centers, como os conhecidos atualmente, surgem nos EUA, essencialmente a partir dos anos cinqüenta, e começam a 
ganhar algum significado na Europa e no Brasil apenas na década seguinte. Vale registrar, entretanto, a existência de algumas concentrações de comércio em edificações, que se assemelhavam e são consideradas precursoras do shopping center, erguidas nos EUA, como o Roland Park (1907), em Baltimore e o Country Club Plaza (1923), em Kansas City, Missouri. Esses prédios congregavam várias lojas de diferentes ramos de atividade, que funcionavam sob uma administração centralizada, nos moldes dos empreendimentos atuais (GRUEN, p.18, apud MASANO, 1993, p.26).

Os Estados Unidos, sem grandes danos físicos ou econômicos provocados pela II Grande Guerra, assistiram, imediatamente ao seu término, a um boom no consumo e, logo em seguida, os shopping centers tomaram impulso e se solidificaram, ao contrário da Europa, que viveu, durante alguns anos, um período de intensa reconstrução. Sem recuperação econômica, crescimento demográfico e melhoria generalizada do bem-estar das populações, o mercado consumidor europeu permaneceu debilitado e, por conseguinte, pouco compatível com o desenvolvimento de novas formas com os requisitos exigidos pelos centros comerciais planejados (MELLO, 2001, p.18).

No Brasil, o primeiro Shopping Center, o Iguatemi, implantado em São Paulo em 1966, se deu em condições sócio-econômicas similares às apresentadas nos EUA, num processo acelerado de urbanização, aumento do poder aquisitivo e do consumo do automóvel em grande escala (MASANO, 1993, p.33).

Foram necessários alguns anos ${ }^{45}$ para que a população se acostumasse com o novo conceito, como já havia ocorrido com os supermercados na década anterior, mas, vencida a desconfiança de lojistas e consumidores quanto à inovação, o êxito do Shopping Center Iguatemi impulsionou a construção de outros shoppings.

\footnotetext{
${ }^{45}$ Após a inauguração do Shopping Center Iguatemi, foram necessários cinco anos até a abertura do seguinte, o Park Shopping, em Brasília.
} 
Dos shopping centers reconhecidos pela $\mathrm{ABRASCE}^{46}$ - entidade que reúne os principais empreendimentos do ramo no Brasil - nos primeiros dez anos, entre 1966 e 1976, foram construídos oito; em apenas cinco anos, entre 1976 e 1981, foram construídos mais oito. Dez anos depois, em 1991, havia 90 empreendimentos, com acréscimo de outros 57 nos cinco anos seguintes, aferindo-se, portanto, um aumento no seu ritmo de implantação. Entre 1996 e 2001, houve o maior crescimento da história no país, quando foram construídos 93 shopping centers. No ano de 2005 o país contava com 260, dos quais, 239 em operação e 21 em construção.

Sua participação foi lenta nas primeiras décadas, tanto que em 1980, ou seja, somente quatorze anos após a inauguração do primeiro shopping brasileiro, as onze unidades existentes até então eram responsáveis por $1 \%$ do faturamento do varejo no país. Entretanto, no final da década de 80 , este percentual já havia atingido os $6 \%$. Numa comparação entre vendas nos shoppings e vendas no comércio varejista, o gráfico 1.1 permite a visualização do crescimento das vendas nos shoppings no período de 1995 a 2002, destacando-se o período entre 1996 e 2000, quando as vendas em shopping centers tiveram desempenho superior ao das vendas do comércio em geral; verifica-se a equiparação das vendas desses dois tipos em 2000 e 2001, assinalando, em 2002, novamente superioridade dos shoppings. Tais resultados mostram que a evolução do comércio vem ocorrendo preferencialmente em shoppings, em detrimento do comércio tradicional.

\footnotetext{
${ }^{46}$ O perfil de mercado será norteado pelos dados, conceitos e critérios da Associação Brasileira de Shopping Centers (ABRASCE), que utiliza normas internacionais e considera somente shoppings tradicionais em suas análises. Ressalta-se, porém, a existência de outras associações que buscam agregar e representar os demais shopping centers e utilizam conceitos diversificados e menos rígidos, como é o caso da Associação Brasileira de Lojistas de Shopping (ALSHOP).
} 


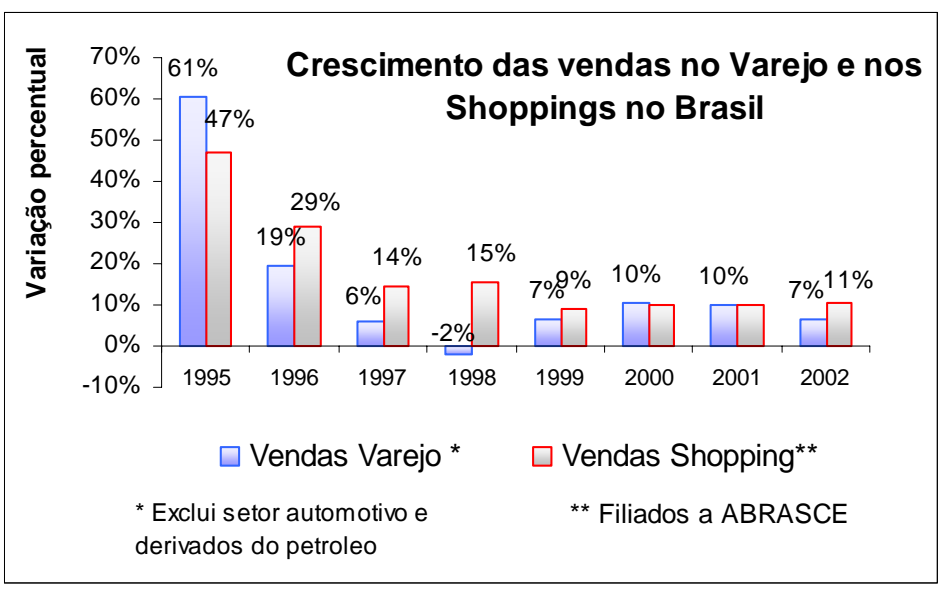

Gráfico 2.1 - Crescimento das vendas no varejo e nos shoppings do Brasil (1994- 2002). Fontes: ABRASCE e IBGE

A localização dos Shopping Centers brasileiros, em geral, seguiu o padrão inner town (fora do centro), mas dentro da mancha urbana. Este foi o caso de todos os shopping centers implantados na cidade de São Paulo, especialmente aqueles inaugurados até a década de 90, com exceção de cidades do interior do estado, onde é possível encontrar alguns com localização out of town, situados às margens de rodovias, visando o afluxo da clientela regional (GARREFA, 2002, p. 44 )

Os primeiros shoppings, principalmente no caso paulistano, vieram a se estabelecer em áreas com alta taxa de urbanização e razoável poder aquisitivo, em regiões urbanas mais centrais, aproveitando a infra-estrutura de equipamentos já existentes, como no caso do Iguatemi (FRUGOLI JR., 1989, p. 41). A Zona Sudoeste do município, além de pioneira, é aquela que abrigou os primeiros shoppings, entre outros fatores, em função do nível de renda da população residente nos bairros das classes de renda mais alta (MASANO, 1993, p. 106). Em 1976 surge o Shopping Center Ibirapuera, que provocou grande adensamento urbano na região de Moema. No início dos anos 80, foram inaugurados o Eldorado (1981) na confluência da avenida Rebouças com a Marginal Pinheiros (em local próximo do Iguatemi) e o Morumbi (1982), próximo à Marginal Pinheiros e à recente avenida Luis Carlos Berrini (com características industriais na vizinhança) [(FRUGOLI JR.,1989, p. 42)]. 
O lançamento do Shopping Center Norte em 1984, na Zona Norte, reverteu a tendência predominante até então da aglutinação junto às elites da Zona Sul, ao ter como público-alvo o consumidor de média e baixa renda e ser acessível por transporte de massa, mostrando que a popularização também poderia auferir sucesso (FRUGOLI JR., 1989, p.45). O apelo a essa ocupação popular passa pela proximidade estratégica de um importante corredor de transporte coletivo de massa, constituído pelo Terminal Rodoviário e pela Estação de Metrô Tietê, além da vizinhança de importante acesso de transporte individual, a Marginal Tietê, e da localização numa região circundante industrial, poluída e de intenso trafego (FRUGOLI JR., 1989, p. 133).

Frugoli Jr. (1989, pp.131- 134) traça um paralelo interessante entre shopping centers e ruas de comércio e coloca que, assim como a sofisticada região da rua Augusta de 1960 serviu de referência na composição de parte do cenário do Iguatemi, para atrair para si o seu público consumidor, o centro tradicional da cidade dos "anos 40" compôs um certo pano de fundo a partir do qual o Center Norte estruturou seu espaço. A rua Barão de Itapetininga, continua Frugoli Jr,, literalmente citado por Baumgart como um calçadão com lojas de bom-gosto, vitrinas discretas, banquinhos de descanso, dentre outros elementos, serviram como referência e, de certa forma, foram recriados no projeto do Shopping Center Norte.

Depois do Center Norte, pode-se constatar a dispersão de shopping centers para fora das áreas mais centrais e, por vezes, direcionando-se às classes de menor renda, tendo os super e hipermercados como a sua grande loja-âncora, como, por exemplo, o Interlagos (1988) na Zona Sul, o Aricanduva (1991) e o Penha (1992) na Zona Leste.

Na análise de ROLNIK (2000), a expansão em direção a regiões periféricas da cidade, localizadas nos fundos da Zona Sul e em vários pontos da Zona Leste, é responsável pelo surgimento de novos padrões de distribuição de mercadorias em áreas que tinham como lugar 
de consumo o pequeno comércio varejista local, os subcentros comerciais tradicionais e o centro do Município de São Paulo.

Entre o período de desenvolvimento do setor e a fase atual, o perfil do mercado mudou: "entre a década de 60 e o final da década de 70, shopping center era sinônimo de varejo de luxo e a concorrência ocorria entre esses centros e o varejo de rua"47. Com a expansão eles passaram a ser acessíveis às mais diversas classes sociais.

O consumidor de baixa renda torna-se o foco de atenção de empreendimentos inteiramente voltados para as classes $\mathrm{C}$ e $\mathrm{D}$, com conceitos de mix de lojas, serviços e lazer compatíveis e focados no poder aquisitivo dos moradores da região, a exemplo dos shoppings Bonsucesso (na divisa entre São Miguel Paulista e Guarulhos) e Campo Limpo (Zona Sul), ambos inaugurados neste ano. O shopping Bonsucesso, com 140 lojas e ancorado por nomes populares como a Casas Bahia e um supermercado atacadista, é um exemplo deste tipo de empreendimento. O shopping traz algumas novidades no conceito, diz o responsável pelo empreendimento, Rafael Ribeiro, como, por exemplo ${ }^{48}$ : i) não estão previstas lavanderia e costureiras porque este público não usa estes serviços; ii) entre as lojas, apesar da presença de marcas conhecidas, pelo menos $40 \%$ devem ser regionais; iii) o valor do ingresso do cinema deve ser mais baixo do que em outros locais para ser compatível com o poder aquisitivo dos moradores da região.

O Shopping Campo Limpo foi o primeiro a ser idealizado e construído com a real participação dos moradores da região. Através de ações multidisciplinares de comunicação, a população local pôde interagir e escolher o "mix" de lojas, serviços e lazer que gostariam de ter no shopping. A estratégia permitiu, ao mesmo tempo, detectar os desejos da comunidade e

\footnotetext{
${ }^{47}$ Panorama Setorial da Gazeta Mercantil. 2000

${ }^{48}$ Fonte: Jornal O ESTADO DE SÃO PAULO, 5/8/2005, "Shopping e o Consumidor de Baixa Renda".
} 
transmitir a sensação de que eles estão construindo o "seu" shopping. Outra curiosidade da campanha é que todos os personagens escolhidos para as peças publicitárias (cartazes, outdoors) são moradores da região, como líderes comunitários e comerciantes. Trata-se de um conceito inovador de interatividade na construção de um empreendimento, onde é possível identificar quais os maiores desejos quanto às lojas, serviços e lazer.

$\mathrm{Na}$ análise da distribuição dos shopping centers no município de São Paulo, não se pode deixar de considerar o acesso como um dos fatores essenciais de sucesso, razão pela qual, via de regra, eles se instalaram em locais que privilegiassem o acesso e a concentração demográfica. O aumento do uso do automóvel, utilizado pela elite e posteriormente também pela classe média (e atualmente até mesmo pelas classes populares), pode ser considerado um dos fatores mais importantes para a maior distribuição do comércio por flexibilizar o acesso (VILLAÇA, 1998, p.328); (LEFEVRE, 1985, p.68).

Embora a maioria desses empreendimentos ainda esteja voltada ao usuário motorizado, associações com estações de metrô também são uma realidade na cidade de São Paulo, através de shoppings construídos em áreas remanescentes do sistema metroviário.

A primeira parceria shopping/metrô se deu em 1997, com a inauguração do shopping Metrô Tatuapé, na Zona Leste da capital, totalmente integrado na estação de mesmo nome.

Em 2001, foi inaugurado o Shopping Metrô Santa Cruz, na zona sul de São Paulo, que já passou por expansão em 2005. Assim também, anexa ao Shopping Metrô Tatuapé está sendo construída uma segunda parte do empreendimento, na outra saída do metrô.

Estas parcerias fazem parte do projeto de comercialização de áreas sem uso, de propriedade do metrô, como forma de aumentar a receita não-tarifária, informa o gerente de novos 
negócios do Metrô de São Paulo, Reinaldo Dinamarco ${ }^{49}$. Isto porque a Companhia do Metropolitano de São Paulo é proprietária dos terrenos e de seu patrimônio - ela faz uma concessão por 50 anos aos empreendedores do shopping e ganha, nesse período, uma participação sobre a receita do aluguel. Segundo informações da Assessoria de Imprensa do governo, há cerca de cinco anos o Metrô comercializa, também, espaços para lojas nas estações $^{50}$.

A atividade comercial, observa Heliana Vargas (2001), é bastante dinâmica, buscando recriar constantemente seu espaço. Isso talvez explique o fato de existirem, na cidade de São Paulo, no início da década de 1990, doze Shopping Centers instalados, contrariando previsões sobre a saturação do mercado. Uma década depois, já eram cerca de duas dezenas de Shopping Centers, dois deles implantados frente a frente (Morumbi Shopping e Market Place).

Nesta dinâmica incluem-se, por exemplo, o preenchimento gradual dos espaços deixados pelas tradicionais de departamentos por decorrência de falência ou concordata de empresas como a Mesbla, o Mappin, a Lojas Brasileiras, por atividades voltadas a serviços, tais como centros de saúde, escolas, academias de ginástica e lazer e entretenimento, com ênfase nos cinemas, que também se apóiam em novas tecnologias para oferecer maior conforto, e que, na década de 1990, passam a ser as novas âncoras dos Shopping Centers.

Os shoppings, como os supermercados e os hipermercados, representam uma grande força de concentração espacial e, de certa forma, eliminam ou reduzem dezenas de quitandas, padarias, açougues, empórios, perfumarias, lojas diversas, dentre outras atividades (Villaça, p.p. 307308).

\footnotetext{
${ }^{49}$ Fonte: http://www.abrasce.com.br/informativos/revistas2004/revset/estacoes.htm.

${ }^{50}$ Os recursos não-tarifários representaram 5,5\% da receita total da empresa, no ano de 2003, com estas formas de comercializar os espaços do Metrô.
} 
Recentemente, um conceito que está ganhando popularidade nos EUA é o modelo de "lifestyle center" $"$ que muda o conceito do espaço fechado para concepção de empreendimentos em espaços abertos, numa espécie de comércio que combina com o comércio tradicional dos centros urbanos, enfim, com a rua comércio ${ }^{52}$. O Brasil está começando a integrar este novo conceito e, caso venha a se concretizar, haverá repercussão direta na configuração espacial da cidade. Segundo LINHARES (2004), os melhores exemplos de lifestyle na cidade de São Paulo são as Alamedas no bairro dos Jardins (não como um empreendimento, mas pelo seu estilo de rua) e o Shopping Higienópolis, apesar de ser um 95\% fechado, o bairro tradicional, direcionou o empreendedor a abrir um pouco à frente do shopping para o bairro, com praça e restaurantes voltados para fora, numa clara intenção de integração com a região. Para VARGAS (1992), o Pátio Higienópolis, inaugurado outubro de 1999, tem formato diferenciado dos shoppings lançados até aquele momento, foi ocasionado parcialmente por exigências da municipalidade, que teve o cuidado de verificar a viabilidade econômica do empreendimento, relacionada à sua economia urbana e aos interesses do da população residente no entorno.

Sejam os espaços comerciais planejados ou não, nota-se crescimento da oferta desses espaços, buscando seus caminhos na mudança de valores do consumidor.

A figura 2.2 sintetiza os fatos marcantes das transformações na atividade comercial desde 1872, quando população da cidade de São Paulo era de 31.385 habitantes (hoje, na casa dos 10.000.000 de habitantes) e as relaciona com a mancha de expansão urbana (Figura 2.1).

\footnotetext{
${ }^{51}$ Geralmente localizado perto de afluentes zonas residenciais, este tipo de shopping reúne o varejo com os estilos de vida do público alvo. Basicamente, possuem malls abertos com design e ambiência agradável, um mix de lojas direcionada para moda e entretenimento e público alvo entre as classes média e alta. Quando o seu bairro é um shopping. Revista Shopping Centers, $\operatorname{dez} / 2004$

${ }^{52}$ Spring Convention. ICSC (International Council of Shopping Centers), Las Vegas 22/05/2005: Em convenção do setor realizada pelo International Council of Shopping Centers (ICSC), foi possível estabelecer a diferença entre um Open Air (um shopping a céu aberto) e um lifestyle center ${ }^{52}$ (que prevê atividades que tenham a ver com o estilo de vida de uma cidade, com ruas praças e multiuso - lojas, escritórios, lazer, alimentação e até residências).
} 

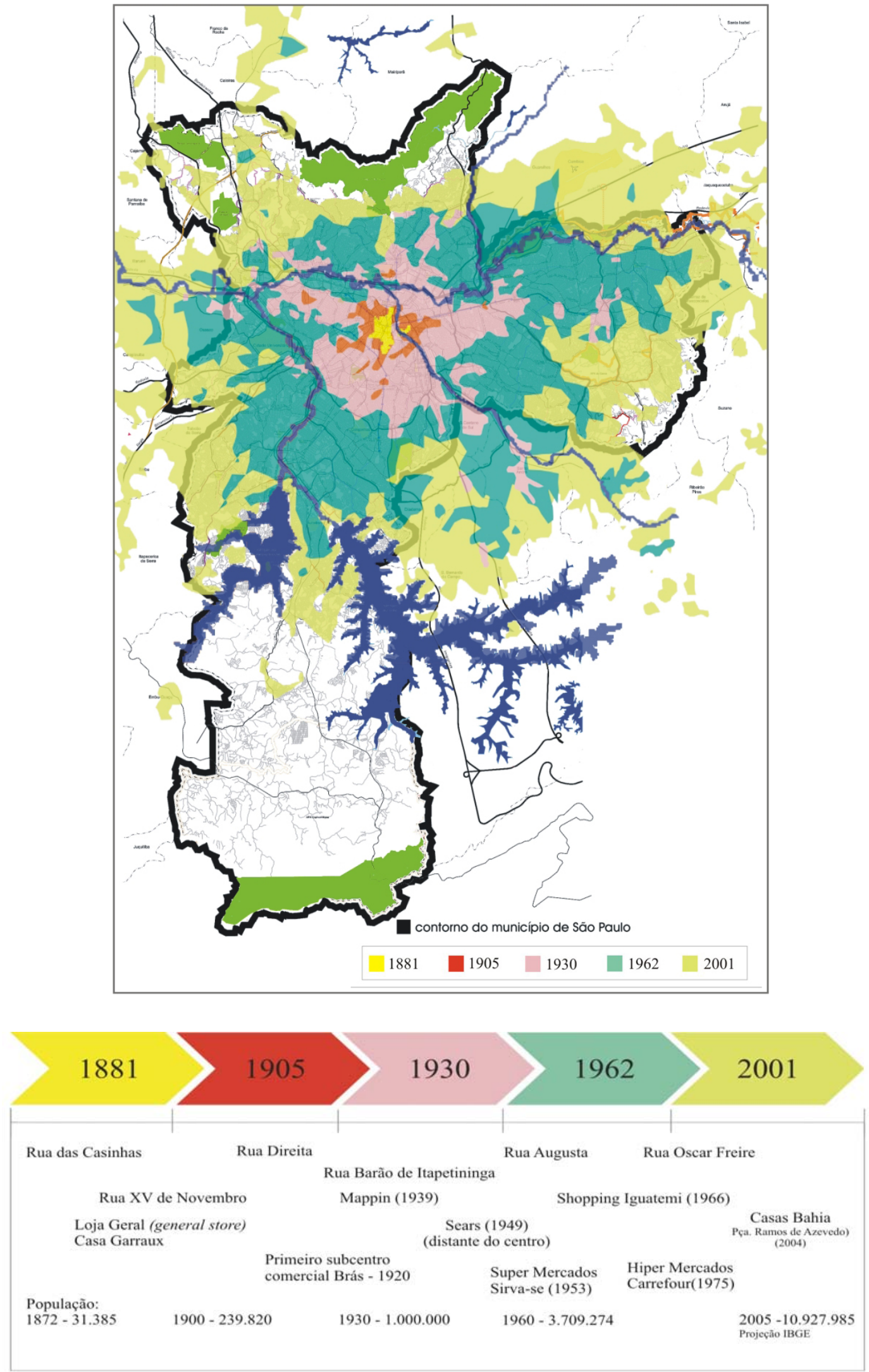

Figura 2.1 Evolução da mancha urbana na cidade de São Paulo, de 1881 a 2001.

Fonte: Elaborado pela autora. Base de dados: Mancha Urbana 1881, Mancha Urbana 1905, Mancha Urbana 1930, Mancha Urbana 1962, Mancha Urbana 2001. (CESAD-FAUUSP).

Figura 2.2 Transformação do comércio e crescimento da população, de 1872 a 2005 Fonte: Elaborado pela autora, 2006. 


\section{TRANSFORMAÇÕES DEMOGRÁFICAS, ECONÔMICAS E SOCIAIS.}

Para retratar as transformações ocorridas no Brasil, no século passado, Thery $(2001$, p. 396) tem como ponto de partida a própria análise da palavra transformações. Segundo o autor, “elas cobrem um campo semântico muito extenso, com muitos sinônimos, com conotações diversas, que indicam uma transição para um outro estado, melhor ou pior”. Entre essas definições, Thery cita alguns sinônimos: "alterações, aperfeiçoamentos, conversões, crescimentos, degenerescências, degradações, desenvolvimento, desgastes, deteriorações, evoluções, expansões, melhorias, metamorfoses, modificações, mudanças, mutações, progressos, retificações, reforços, reformas, renovações, revoluções, transmutações, transtornos".

O Brasil do século XX, como constata Thery, ao recuar tantos anos no tempo, conheceu quase todos os tipos de evolução e progrediu na maioria dos campos. Thery justapõe, em gráfico, as curvas da população (total, urbana) e alguns indicadores de riqueza (PIB, número de automóveis e televisores) [Tabela 3.1].

\begin{tabular}{|c|c|c|c|c|c|c|c|c|}
\hline \multirow[b]{2}{*}{ ANO } & \multicolumn{2}{|c|}{ POPULAÇÃO } & \multicolumn{2}{|c|}{ PIB } & \multicolumn{2}{|c|}{ AUTOMÓVEIS } & \multicolumn{2}{|c|}{ TELEVISORES } \\
\hline & (milhões) & semilog & $\begin{array}{r}\text { (milhões } \\
\text { US\$) }\end{array}$ & semilog & (milhares) & semilog & (milhares) & semilog \\
\hline 1890 & 14 & 1 & & & & & & \\
\hline 1920 & 30 & 2 & & & & & & \\
\hline 1940 & 41 & 3 & & & 120 & 1 & 141 & 1 \\
\hline 1956 & & & & & 280 & 2 & 600 & 4 \\
\hline 1950 & & & 19 & 1 & & & 2300 & 16 \\
\hline 1960 & 70 & 5 & & & 650 & 5 & 4600 & 33 \\
\hline 1966 & & & & & & & 11600 & 82 \\
\hline 1970 & 93 & 7 & 45 & 2 & 2600 & 22 & 18300 & 130 \\
\hline 1976 & & & & & & & 26500 & 188 \\
\hline 1980 & 119 & 9 & 250 & 13 & 10800 & 90 & & \\
\hline 1990 & 146 & 10 & 463 & 20 & 18300 & 153 & & \\
\hline 1995 & & & & & & & 31600 & 224 \\
\hline 1996 & 157 & 11 & 774 & 40 & 26200 & 208 & & \\
\hline 2000 & 166 & 12 & & & & & & \\
\hline
\end{tabular}

Tabela 3.1 - Crescimento da População, do PIB e dos equipamentos domésticos (Automóveis e Televisores) e transformação em escala semilogarítimica

Fonte: Thery, 2001 
Construído usando uma escala semilogarítmica, para transformar uma progressão regular numa reta, o Gráfico 3.1, mostra que, se a população cresce, quase retilineamente, o PIB sobe mais rapidamente ao longo do século (apesar das sinuosidades causadas pelas crises) seguido de perto pelas curvas dos dois equipamentos (automóveis e televisores), que mais mudaram o cotidiano dos brasileiros.

A curva de difusão dos equipamentos continua Thery, se aproxima de uma curva logística, com aclives fortes no início (nos decênios de 1960 e 1970), seguidos de segmentos mais achatados quando a saturação começa a se manifestar, fase que começa na década de 1990 . Tomando como referência os anos de 1940 e 1956, o total de carros e de televisores foi multiplicado por mais de duzentos.

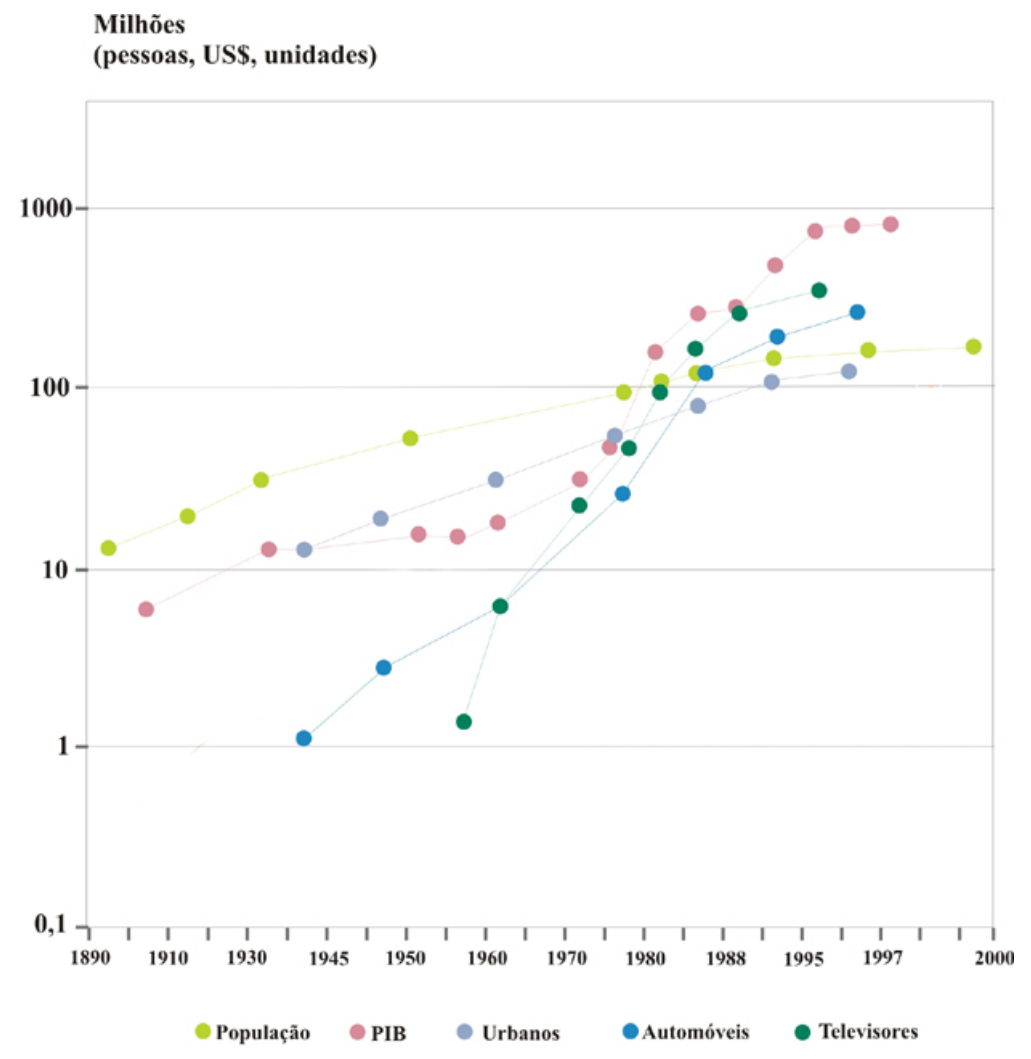

Gráfico 3.1 Crescimento da população (total e urbana), do PIB, de automóveis e de televisores. Fonte: Thery , 2001 
A situação da cidade de São Paulo expressa as condições gerais da economia brasileira, porém apresenta peculiaridades. Ao longo do século XX, a população da cidade de São Paulo cresceu aproximadamente quarenta vezes, da ordem de 240 mil pessoas em 1900, passou para quase 10.500.000 em 2.000. De uma cidade de médio porte dominada pelas atividades de serviços na metade do século XIX, ancorada no ciclo cafeeiro, São Paulo transformou rapidamente seu perfil econômico e social, centrando suas atividades no setor industrial. O avanço do processo de industrialização e a explosão do crescimento populacional, nos anos de 1950 e 1960, se expandiram para os municípios vizinhos, consolidando a região metropolitana de São Paulo. Em duas ou três décadas constituiu-se uma cidade com dominância do setor industrial na geração do produto e do emprego e, em cinco décadas, essa configuração foi transformada, dando proeminência ao setor de serviços. Em 1991, a indústria da transformação respondia por $24 \%$ da ocupação do mercado de trabalho paulistano, próxima à metade da participação encontrada em 1940. Na virada do século, sua participação decrescia para $16,21 \%$, quando o setor de serviços respondia por mais da metade da população ocupada de São Paulo (52,01\%). O setor do comércio, que em 1940 respondia por 16,42\% da ocupação do mercado de trabalho paulistano, caiu para 14,9\% em 1991 e depois recuperou-se, atingindo16,36\% (DEDECCA, 2004, pp. 241-242).

\begin{tabular}{|c|c|c|c|}
\hline Setores & $\mathbf{1 9 4 0}$ & $\mathbf{1 9 9 1}$ & $\mathbf{2 0 0 0}$ \\
\hline Agricultura & $3,41 \%$ & $0,7 \%$ & $0,26 \%$ \\
\hline Indústria da Transformação & $45,67 \%$ & $24,77 \%$ & $16,21 \%$ \\
\hline Comércio & $16,42 \%$ & $14,90 \%$ & $16,36 \%$ \\
\hline Serviços & $26,08 \%$ & $45,79 \%$ & $52,01 \%$ \\
\hline
\end{tabular}

Tabela 3.2 População ocupada por setor de atividade. Município de São Paulo 1940-1991-2000 Fonte: Censos Demográficos (Dedecca, 2004) 
Os dados da Fundação Seade apontam, para 2002, uma distribuição da massa salarial da seguinte ordem: $11,2 \%$ no comércio, $18,4 \%$ na indústria e $70,4 \%$ nos serviços.

A crise brasileira esboçada acima atingiu duramente a cidade: os sinais de desindustrialização já eram visíveis na década de 1980 e os empregos diminuíram. Em 1985, o desemprego total chegou a um pico de 12,2\%, declinou um pouco e, a partir de 1991, começou nova elevação, culminando nos 18\% de 2005. (Fundação Seade, Pesquisa PED, para a RMSP, 2005).

Há dez anos, a região abrigava cerca de 1,6 milhões de desempregados, enquanto o rendimento médio real caía de 1.953 reais em 1985 para 1.015 reais em 2004, perda de 50\% do poder aquisitivo.

Essas transformações sociais, demográficas e econômicas refletem diretamente no crescimento do comércio informal e do mercado consumidor das classes populares, com conseqüências diretas na atual configuração da rua de comércio.

\section{1 - Comércio informal transforma rua de comércio em comércio de rua}

No Brasil, a tradicional existência do setor informal esteve associada a uma insuficiente, ainda que dinâmica, geração de emprego no setor formal.

Pela pesquisa da Economia Informal Urbana do IBGE, em 2003, foram identificadas 10.525.954 pequenas empresas não-agrícolas no país, com superioridade de 10 em relação às estimadas em 1997. Grande parte das empresas do setor informal pertencia a trabalhadores por conta própria ( $88 \%$ ) entre os quais, apenas $12 \%$ de pequenos empregadores. As atividades econômicas preponderantes neste setor eram comércio (33\%), construção civil $(17 \%)$ e indústria de transformação e extrativa (16\%). 
Tal fato é evidenciado pelo aumento no grande e heterogêneo setor de atividades econômicas informais, majoritariamente comércio e serviços. Uma das conseqüências da informalização do emprego é a expansão do "comércio de rua".

O crescimento recente das ocupações do setor informal no Brasil, e em particular na Região Metropolitana de São Paulo (RMSP), foi analisado por Pamplona (2001; 2004). O autor correlaciona esse crescimento às mudanças estruturais e instabilidade macroeconômica, as quais as duas compeliram as empresas a um grande esforço de reestruturação e geraram expressivas mudanças no mercado de trabalho.

Com a acentuada redução do dinamismo econômico do setor formal em termos de geração de empregos, na década de 1990, especialmente do emprego industrial, a informalidade se torna uma alternativa para muitos trabalhadores, sejam eles ex-assalariados, desempregados do setor formal, sejam eles trabalhadores que fizeram sua inserção ocupacional no setor informal e daí não tiveram chance de sair (Pamplona, 2004, p.318).

Na década de 90, destaca o autor, na RMSP, verificou-se uma evolução do número de ocupados no setor informal: a participação da ocupação informal na RMSP passou de 25\% para 33\% entre o biênio 1988-1989 e o biênio 1998-1997. Houve uma elevação absoluta estimada de 761 mil pessoas e uma relativa de $48 \%$ no contingente de trabalhadores informais metropolitanos.

Com relação aos auto-empregados ${ }^{53}$, continua o autor, a trajetória de crescimento continuou nos anos mais recentes, na RMSP. Os auto-empregados (autônomos, pequenos empregadores e donos de negócio familiar), que representavam cerca de $18 \%$ da ocupação no biênio 1988-

\footnotetext{
53 O auto-emprego é uma situação de trabalho na qual o trabalhador independente controla seu processo de trabalho; fornece a si mesmo seu equipamento, o que permite que o proprietário dos meios de produção participe diretamente da atividade produtiva; não tem renda previamente definida; tem por objetivo primordial prover seu próprio emprego (meio de subsistência), e não valorizar seu capital (acumulação de capital) (PAMPLONA, 2001, p.78).
} 
1989, passaram a representar $24 \%$ no ano de 2001. Baseando-se nos dados da PED, ele chega ao resultado de 600 mil pessoas a mais, elevando o contingente estimado de auto-empregados em 2001 para algo como 1.800 .000 pessoas (PAMPLONA, 2000; FUNDAÇÃO Seade, 2002).

Oficialmente, de acordo com a Lei n.11.009, de 23 de agosto de 1991:

\begin{abstract}
"Considera-se vendedor ou prestador de serviços nas vias e logradouros públicos, reconhecido como ambulante, a pessoa física, civilmente capaz, que exerça atividade lícita por conta própria ou mediante relação de emprego, desde que devidamente autorizada pelo poder público competente" (São Paulo, Município, 1991, apud PAMPLONA, 2004, p.311).
\end{abstract}

A questão do comércio ambulante é delicada e, sem entrar em detalhes sobre a questão social e econômica que envolve o comércio informal, que foge ao escopo deste trabalho, o fato é que, concentrados de forma caótica nas ruas de comércio, ocupando as calçadas destinadas aos pedestres e, por vezes, partes da própria rua, principalmente nas de maior concentração, as do centro tradicional e as de bairro (ou os subcentros populares), os ambulantes têm contribuído para um longo processo de deterioração desses espaços pelo desconforto, sujeira e insegurança. Eles escondem as vitrines de lojas e, por vezes, concorrem com os mesmos produtos, transformando o que era "rua de comércio" em "comércio de rua".
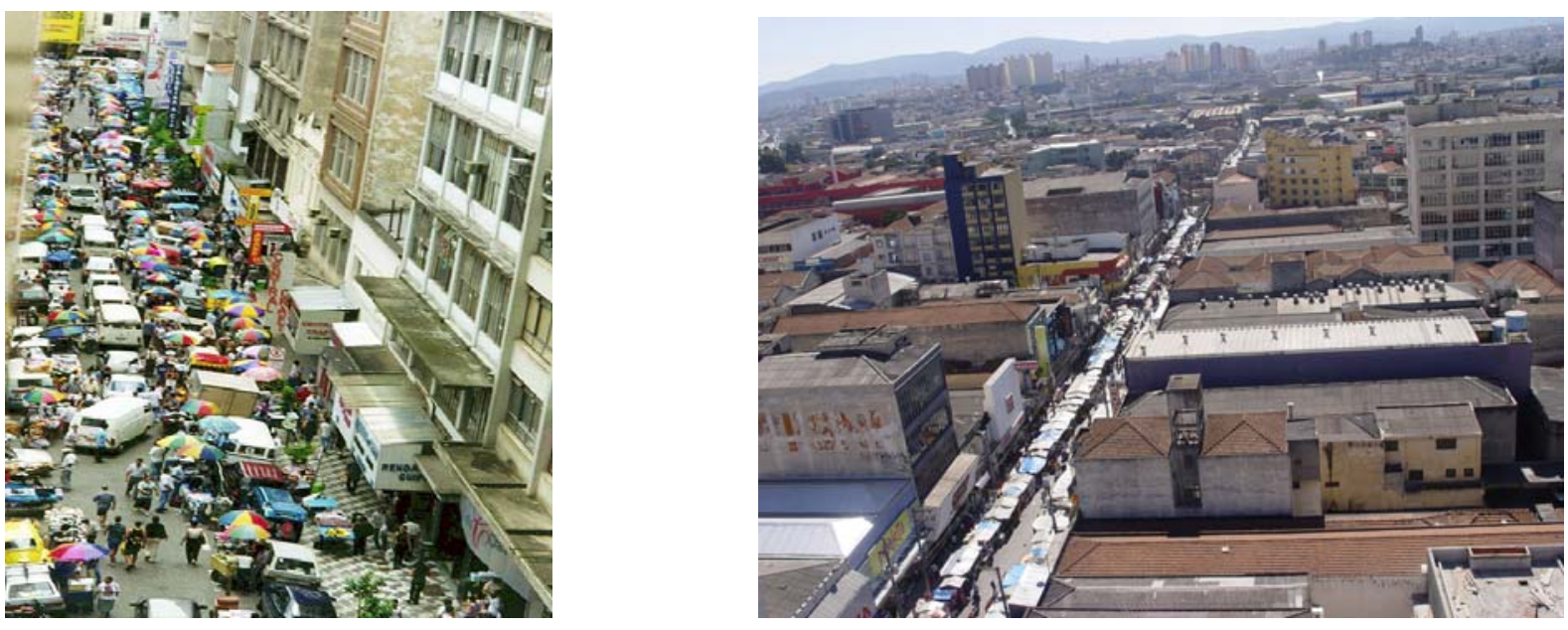

Foto 3.1: Rua Vinte e Cinco de Março Fonte: NAUFEL, Felippe (2005).

Foto 3.2: Rua Doze de Outubro, Lapa Fonte: Autora, agosto, 2005. 

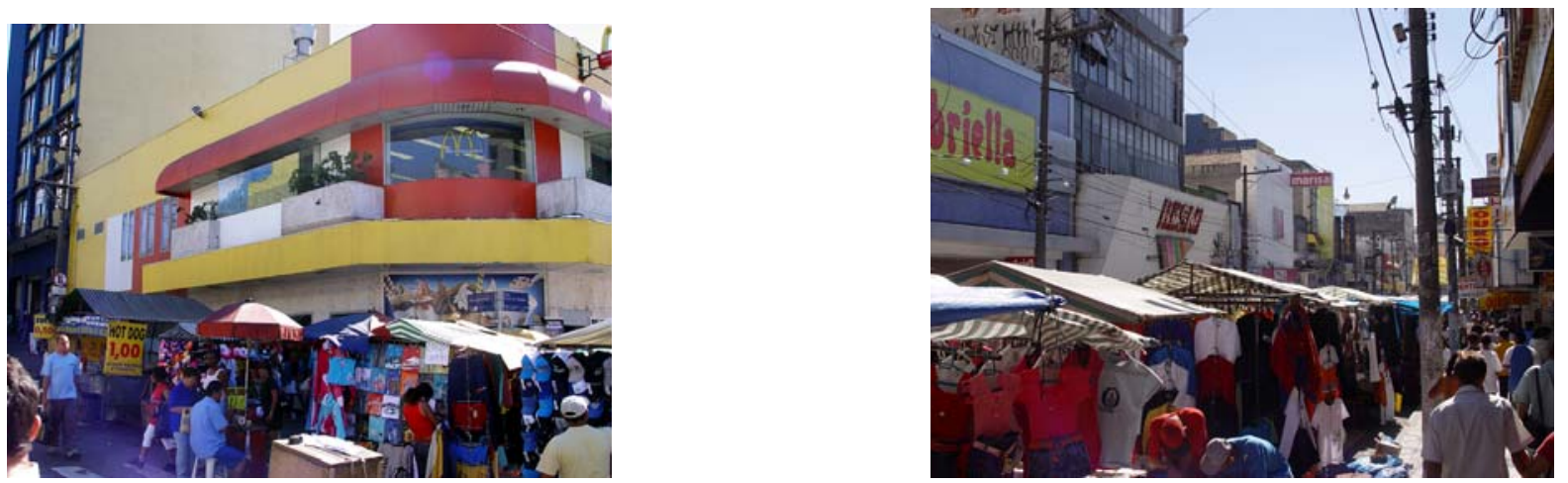

Foto 3.3: Rua Doze de Outubro, Lapa Fonte: Autora, agosto, 2005.

Foto 3.4: Rua Doze de Outubro, Lapa Fonte: Autora, agosto, 2005.

\section{2 - Crescimento do consumidor das classes populares}

A estrutura do varejo brasileiro sempre esteve intimamente relacionada à estrutura econômica vigente no país. No desempenho recente do setor, dois processos foram decisivos: a abertura da economia, iniciada em 1990 e a estabilização econômica, com a implantação do Plano Real em julho de 1994. A abertura da economia promoveu o aumento da concorrência em todos os setores do varejo brasileiro, liberação das importações, maior variedade dos produtos ofertados, realinhamento de preços no setor e a entrada no mercado de cadeias internacionais. O Plano Real, a. estabilidade da moeda e o aumento de poder aquisitivo da população, especialmente a de mais baixa renda, resultaram no crescimento do consumo, aumento do faturamento das empresas, da concorrência e exigência de maior eficiência nas operações. (SANTOS; COSTA; CARVALHO, 1996).

Com a estabilidade do ambiente econômico pós-Real e as políticas de estabilização econômica, surge como fator de mudança no comércio varejista a "descoberta" dos consumidores de baixa renda, sobretudo os oriundos das classes $\mathrm{C}$, um importante segmento de consumo nas classes populares (The Boston Consulting Group, 2002). 
Essas transformações têm explicações num importante movimento de migração de parte da classe D para o degrau da classe C. Em 1991, segundo dados do IBGE, a classe $C^{54}$ representava $26,3 \%$ da população e estava espremida entre os $15,8 \%$ da classe B e os $38,6 \%$ da classe D. Já em 2001, a classe C passou a representar 30,9\% da população e a D, 33,8\%. Nesse período, o índice de mobilidade social médio foi de $2,5 \%$ em direção ao topo da pirâmide, permeando todas as classes. (The Boston Consulting Group, 2002).

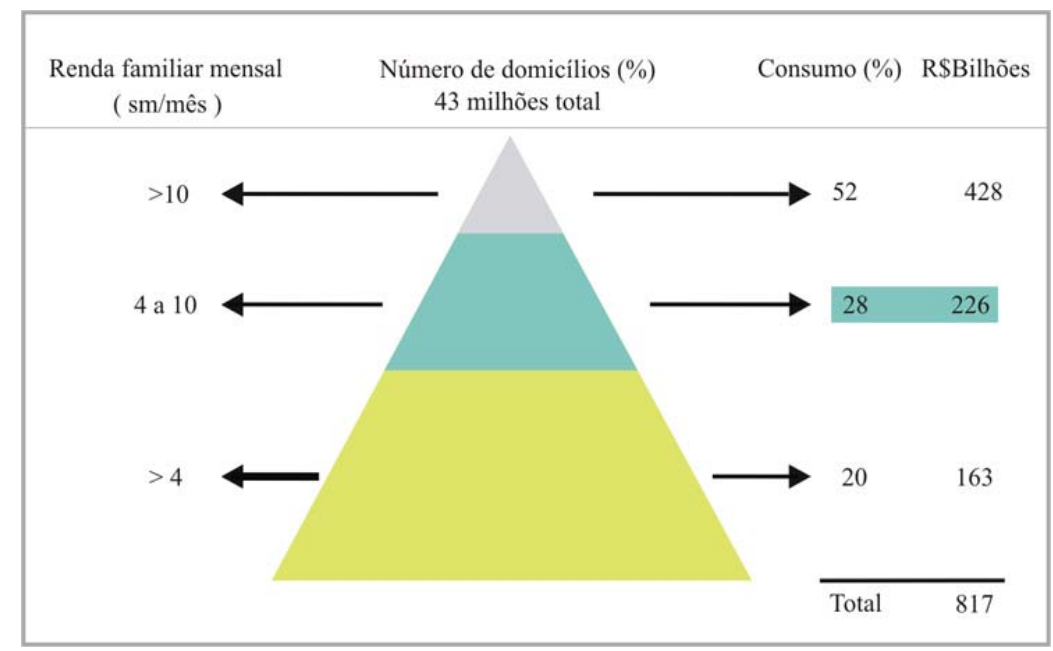

Gráfico 3.2 - Classificação sócio econômica das classes A/B, C e D Fonte: Target 2000//PNAD99 (The Boston Consulting Group, 2002)

A classe $\mathrm{C}$ possui renda familiar mensal entre quatro e dez salários mínimos e é constituída por cerca de $30 \%$ dos domicílios do país (12 milhões do total de 43 milhões de domicílios do país). É responsável por $28 \%$ do consumo nacional, equivalente a $\mathrm{R} \$ 226$ bilhões por ano, em compras (Gráfico 3.2).

\footnotetext{
${ }^{54}$ Classificação socioeconômica, no caso, é definida pelo seu potencial de consumo, suas necessidades e seu comportamento de compra. $\mathrm{O}$ consumidor da classe $\mathrm{C}$ possui renda familiar mensal entre quatro e dez salários mínimos (R \$ 151,00 base 2001; R \$300, base 2005). Alimentação e moradia são os itens que mais consomem os recursos da classe C: respondem por $65 \%$ dos gastos mensais. Esse percentual divide-se em gastos com supermercado - $48 \%$, e com a manutenção do domicílio (água, luz, aluguel, condomínio, prestação da casa e IPTU) - 17\%. Já o lazer representa apenas 3\% dos gastos mensais. Já as classes D e E somam uma renda familiar inferior a 4 salários mínimos mensais e representam a maioria da população.
} 
Pesquisas do Instituto Target Marketing ${ }^{55}$ cruzadas com dados coletados pelo Instituto Brasileiro de Geografia e Estatística (IBGE) mostram, além do crescimento da classe C (de 26,3\% da População Economicamente Ativa (PEA) em 1991 a 37,9\%, em 2005), o aumento da participação dessa classe no consumo total urbano do país de $23,8 \%$ para 27,2\% no mesmo período (Gráfico 3.3)

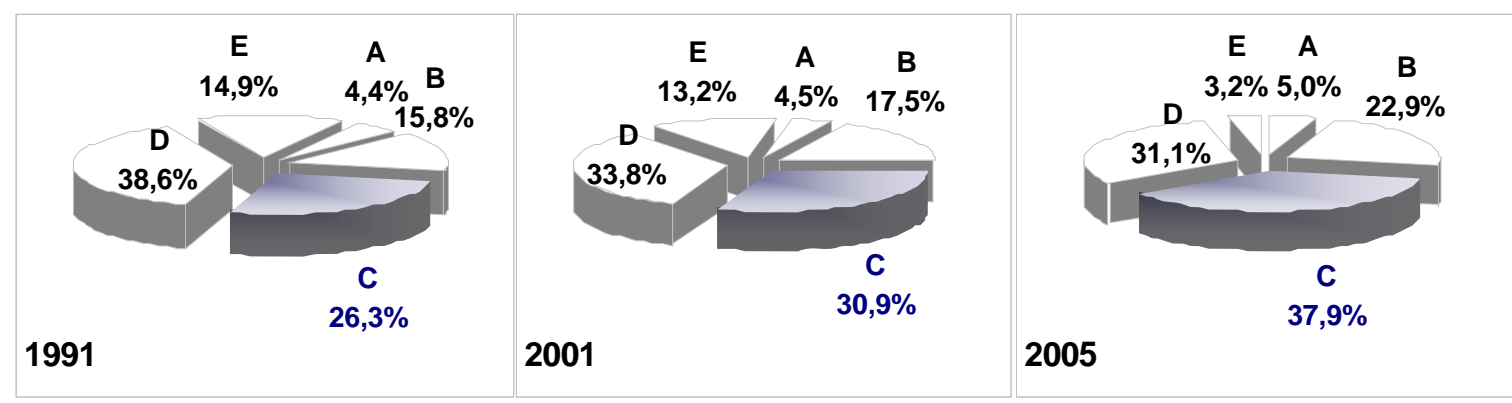

Gráfico 3.3 - Ascensão da Participação no Consumo da Classe C (1991, 2001, 2005)

Fonte: Instituto Target Marketing (2005)

Para AMARAL Júnior (EAESP-FGV, 2005), não basta oferecer apenas preço baixo para os consumidores das classes C, D e E (que representam $77 \%$ da população brasileira). Sua realidade econômica e hábitos de consumo, continua o autor, passaram por uma grande mudança na última década, alterando profundamente seu comportamento. Há dez anos, conclui, esse público consumia um rol de serviços e produtos limitados; entretanto, a lista de itens cresceu e diversificou-se, passando a incluir outros tipos de interesse, como celular e internet.

\footnotetext{
${ }^{55}$ Fonte: PAZZINI, Marcos. Tendências sociais, demográficas e econômicas: Quais os vetores de expansão no Brasil? Seminário GV CEV “Localização e expansão no Varejo:Técnicas e Alternativas de Crescimento", FGVEAESP. São Paulo, agosto de 2005. Pazzini ressalta que a classe C cresceu tanto em número de domicílios como em valores monetários de consumo, porque houve ascensão social das camadas de menor renda, E e D, principalmente, as quais tiveram seu tamanho diminuído. Ele observa que a classificação por classes sociais leva em conta não apenas a renda, mas também a posse de bens "Não se trata de uma melhora na condição dos brasileiros, mas sim de uma adequação da pesquisa à queda média verificada na renda da maioria dos brasileiros. Domicílios com renda média de um salário mínimo integram, hoje, a classe E; antes era preciso dois salários para ser classe E”.
} 
Além destes fatores, é preciso levar em conta a expansão do crédito ao consumidor, que chegou a representar 7\% do Produto Interno Bruto (PIB) em 1972 - atualmente sua representatividade chega a $30 \%$ - e possibilitou a expansão da indústria de bens e consumo duráveis (automóveis, eletroeletrônicos, móveis) no país ${ }^{56}$.

Estas oportunidades de mercado são assimiladas e rapidamente incorporadas pelos empreendimentos planejados inteiramente voltados para as classes C e D, com conceitos de mix de lojas, serviços e lazer compatíveis e focados no poder aquisitivo dos moradores da região, a exemplo dos shoppings Bonsucesso (na divisa entre São Miguel Paulista e Guarulhos) e Campo Limpo (Zona Sul), ambos inaugurados neste ano, enquanto que as ruas de comércio têm suas evoluções espontaneamente vinculadas à demanda do próprio mercado.

Embora essas reflexões possam provavelmente aplicar-se a vários segmentos que compõem o mercado de consumo brasileiro, não há dúvidas de que o crescimento do consumo das classes populares é um dos fatores que podem estar contribuindo para a dinâmica das ruas de comércio na cidade de São Paulo, principalmente para as do centro tradicional e das zonas de bairro com características populares (Rua Voluntários da Pátria, rua Doze de Outubro, rua Teodoro Sampaio, Largo Treze, entre outras).

O aumento do consumo da população de baixa renda e a maior facilidade ao credito trazem às ruas de comércio das cidades uma quantidade enorme de financeiras, como Itaií do Banco Itaú e Íbis da C\&A Modas, instaladas estrategicamente em áreas voltados diretamente para as calçadas, ocupando, inclusive, espaços de lojas e retomando uma pratica antiga do varejo de rua, que é a "abordagem ao consumidor", dando um novo dinamismo à rua de comércio.

\footnotetext{
56 Fonte: Jornal Diário do Comércio, 23/02/06. E os brasileiros foram às compras. Disponível em $<$ http://www.dcomercio.com.br/noticias..htm $>$
} 

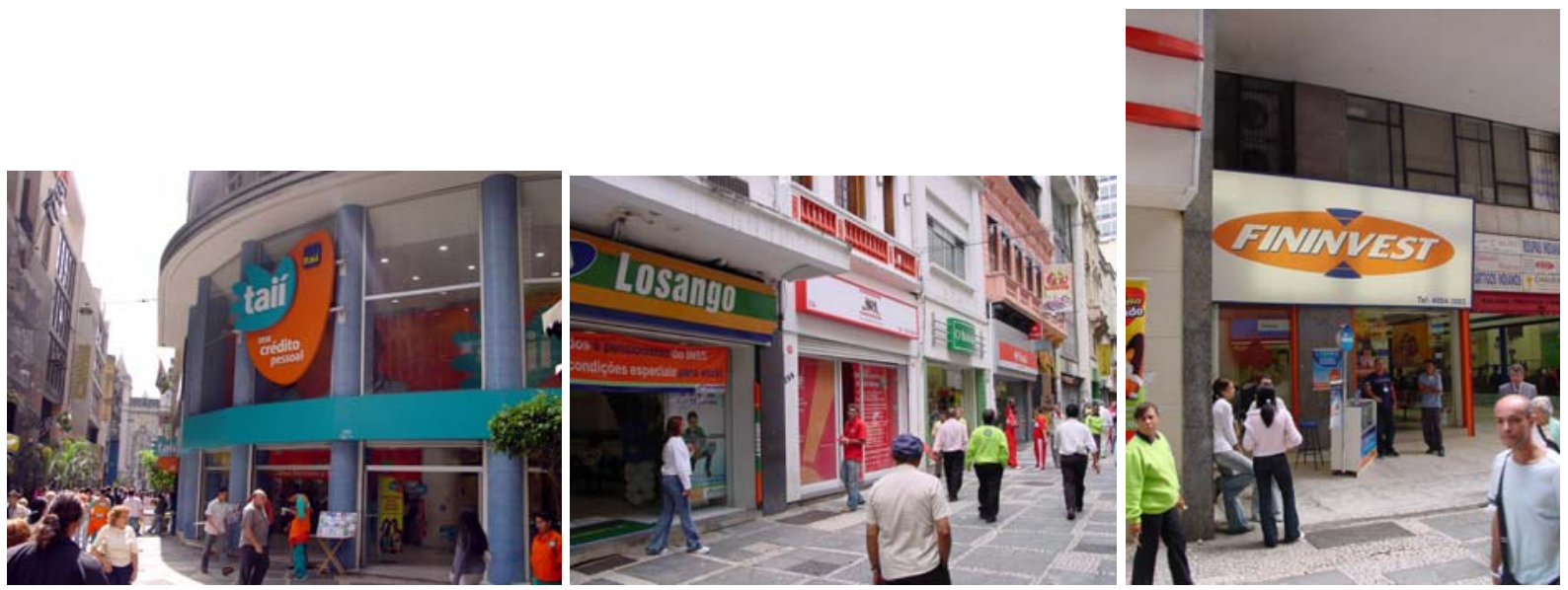

Foto 3.5: Financiadora Itaí, Rua São Bento Fonte: Autora, agosto, 2006.

Foto 3.6: Financiadoras Losango, JRL, Finasa, Rua São Bento Fonte: Autora, agosto, 2006.

Foto 3.7: Financiadora Fininvest, Rua São Bento Fonte: Autora, agosto, 2006.

A distribuição dos domicílios por renda familiar na cidade de São Paulo Pesquisa da Fundação Seade (2000) ilustra o seguinte quadro: 37\% até 5 salários mínimos, 26\% de 5 a 10 e 37\% acima de 10 salários mínimos. Com estes índices é possível compreender por que há espaço para o crescimento do pequeno comércio na periferia, das ruas de comércio em bairros de classe média e para a expansão de shopping centers.

A Casas Bahia ${ }^{57}$ tem, no varejo nacional, um modelo que viabiliza o consumo de baixa renda brasileira através do credito e é um típico exemplo, que confirma estas observações. A empresa possui uma forma muito peculiar de crescer, voltada a camadas de renda mais baixa, as classes C e D. Na cidade de São Paulo, a Casas Bahia orienta sua estratégia de localização principalmente em ruas de comércio em áreas densamente povoadas: das 92 lojas existentes,

\footnotetext{
${ }^{57}$ A Casas Bahia fundada em 1952, pelo imigrante de origem judaica Samuel Klein, que começou vendendo colchas e lençóis de casa em casa, a bordo de uma carroça, pelas ruas de São Caetano do Sul (SP), hoje possui 504 lojas em oito estados brasileiros.
} 
77 (ou 83 \%) estão localizadas em ruas de comércio, e apenas $17 \%$ ou 15 lojas estão localizadas em shopping centers ${ }^{58}$.

A maior loja da rede localiza-se no centro, na Praça Ramos de Azevedo, no prédio que foi um ícone da história, no qual funcionou por 60 anos uma loja do Mappin ${ }^{59}$, até sua falência decretada em 1999. Os principais subcentros comerciais populares - rua Doze de Outubro (Lapa); rua Teodoro Sampaio (Pinheiros) e rua Voluntários da Pátria (Santana) - apresentam três lojas em cada uma destas ruas e uma no Largo Treze (Santo Amaro). Podem-se verificar ainda lojas espalhadas em outros 49 (quarenta e nove) endereços (fig. 3.1).
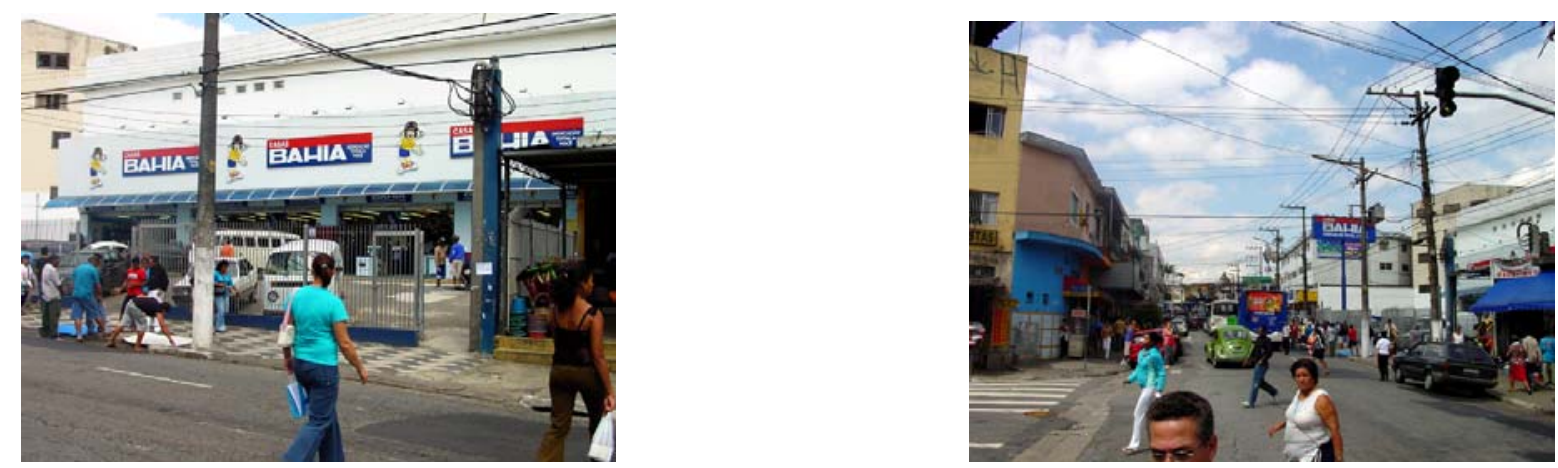

Foto 3.8: Loja Casas Bahia, avenida Itaberaba, Zona Norte Fonte: Autora, março, 2006

Foto 3.9: Avenida Itaberaba, Zona Norte, onde está instalada loja das Casas Bahia.

Fonte: Autora, março, 2006

\footnotetext{
${ }^{58}$ Fonte: site da Casas Bahia $<$ http:www.casasbahia.com.br> acesso em fevereiro 2006.

${ }^{59}$ O local, de dezembro de1999 a setembro de 2003 foi ocupado por uma loja do Hipermercado Extra, da CBD (Companhia Brasileira de Distribuição).
} 


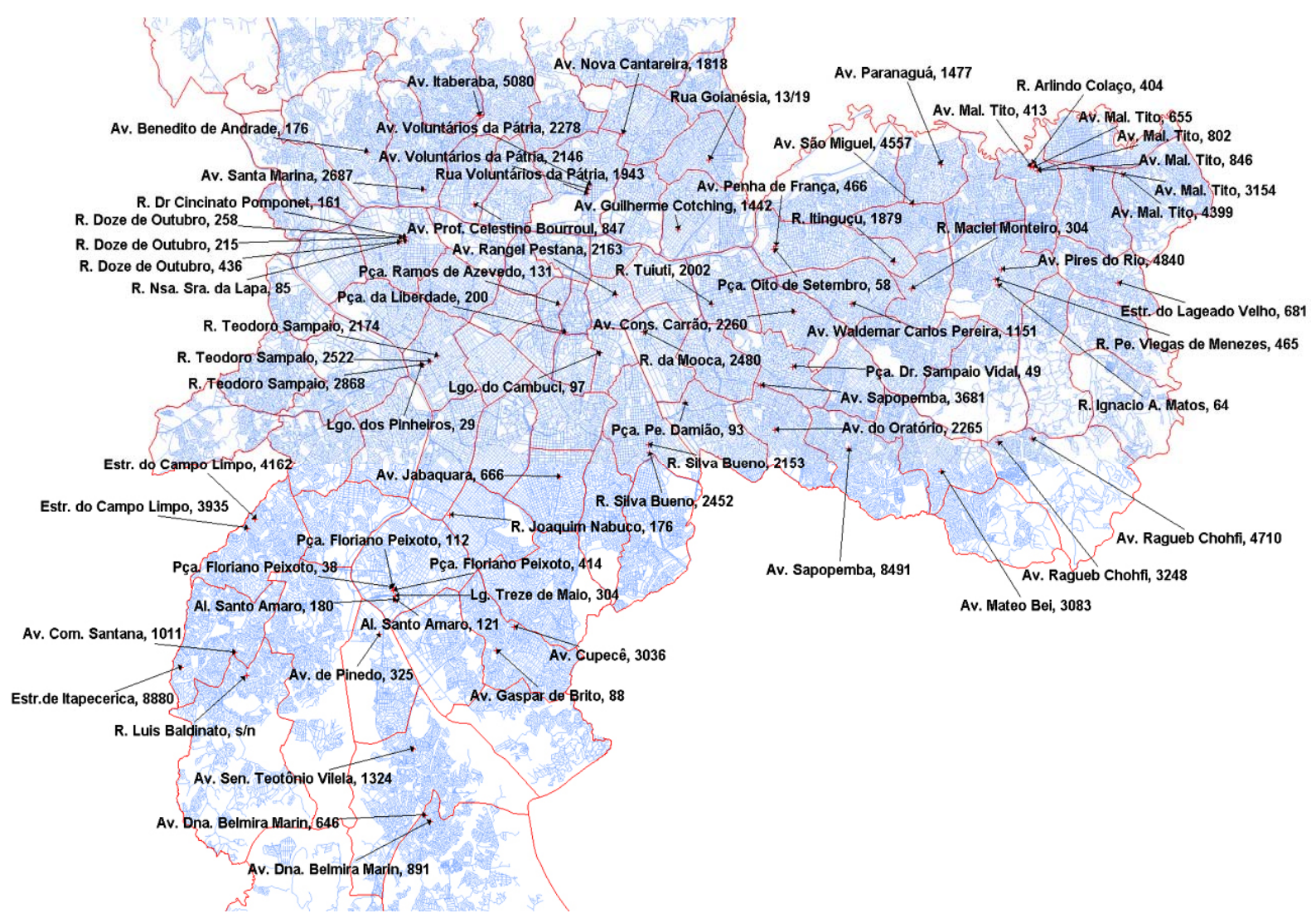

Fig. 3.1- Mapa com dispersão de lojas da Casas Bahia na cidade de São Paulo.

Fonte: Autora, 2006

No passado, a loja Mappin Stores ajudou a contar o início da história do comércio de São Paulo quando este se resumia no seu centro histórico (VARGAS, 2001, p.276); em 1913, foi inaugurado na rua 15 de Novembro para atender a elite cafeeira; seis anos depois, mudou-se para a Praça do Patriarca e, em 1939, novamente, mudou-se para o prédio da Praça Ramos (Barão de Itapetininga), tornando-se um símbolo de lojas de departamentos na cidade até a abertura dos shoppings, entre o final dos anos 60 e início dos 70.

Atualmente, a Casas Bahia pode contribuir para contar a história do comércio em função de outra realidade, não mais a do comércio da elite daquela época, mas a do comércio das classes populares. A Casas Bahia pode contar a história de hoje, numa condição de semelhança com o Mappin, não só pelo fato de estar ocupando o prédio, que foi seu símbolo e o "ponto" da Praça Ramos, mas, também, pela habilidade da empresa em entender os hábitos de compra 
dos consumidores de baixa renda e a capacidade de viabilizar o consumo por meio do acesso ao crédito, o que resultou num modelo especial no que diz respeito ao varejo.
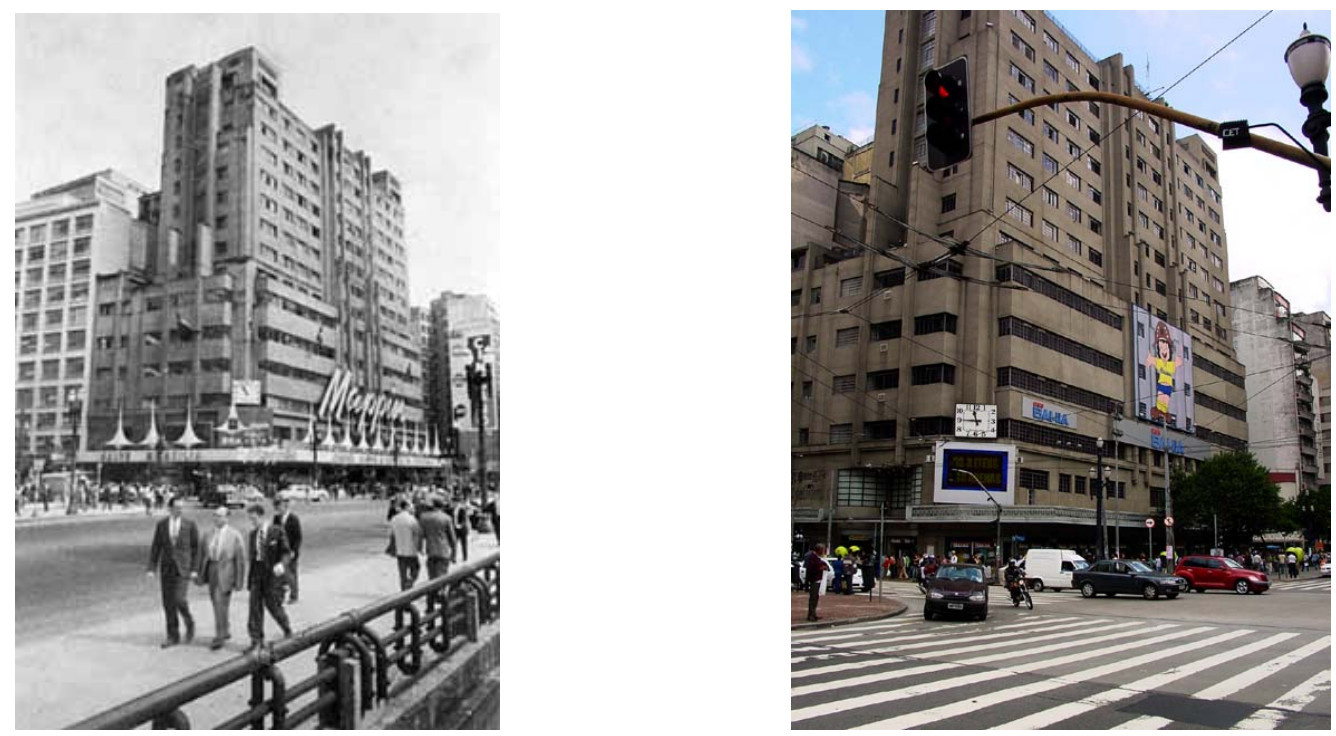

Foto 3.10: Lojas Mappin, prédio na Praça Ramos, 1960

Fonte: Folha imagem $<$ http://almanaque.folha.uol.com.br/saopaulo $>$, fev.2006

Foto 3.11: Casas Bahia, prédio da Praça Ramos, a parir de dezembro de 2004 Fonte: Autora, março, 2006.

Diferentemente daquela época em que o Mappin ocupava apenas um ponto na cidade, a Casas Bahia fez-se espalhar por toda cidade, o que mostra não só um novo modelo de varejo, mas também uma nova realidade urbana e socioeconômica.

A Casas Bahia ${ }^{60}$, fiel ao seu modelo de vendas pelo crediário, não vende pela internet ${ }^{61}$ e o pagamento das prestações é feito somente nas próprias lojas. Cerca de $6 \%$ dos clientes, ainda pagando um carnê, fazem uma segunda compra.

\footnotetext{
${ }^{60}$ Pelo balanço anual de 2005, divulgado pela Casas Bahia, a empresa fechou 2005 com 23 milhões de clientes, dos quais 21,5 milhões clientes ativos, ou seja, compram sempre na rede. Cerca de 22,8 milhões de pessoas passaram pelo crediário da rede e 18,5 milhões de clientes tiveram financiamento aprovado. Do total de suas vendas, cerca de $70 \%$ são feitas a crédito. De cada 100 clientes, cerca de 70 , com ganhos equivalentes a dois salários mínimos mensais, não têm como comprovar renda e, nem por isso, a inadimplência é maior (Fonte: Diário do Comércio e Indústria, 24 de janeiro de 2006).

${ }^{61}$ A rede varejista Casas Bahia, pelo menos por enquanto, não pretende investir no segmento de vendas pela internet e a sua prioridade é a regionalização, com vendas voltadas para as classes $\mathrm{C}$ e D. Fonte: O Estado de São Paulo - "Casas Bahia mantêm estratégia de expansão". Pág. B 20 [01/06/2005]
} 
Se, nos anos 1930, o Mappin funcionou como forte indutor da urbanização e , atrás de si, uma série de outros estabelecimentos comerciais, especialmente para a rua Barão de Itapetininga, como relatam Alvim e Peirão (1985; p. 136); hoje, a Casas Bahia tem o poder de induzir a uma nova dinâmica na rua, não só por seu poder de atração do consumidor, como também por sua estratégia de pagamento de carnês na própria loja, que faz o consumidor retornar à loja mensalmente, contribuindo para que o fluxo na própria loja seja estendido para as ruas de comércio onde está instalada. 


\section{HÁBITOS DE COMPRAS E A RUA DE COMÉRCIO}

Este capítulo tem como objetivo estudar os hábitos de compra do consumidor relacionados com as ruas de comércio.

Para atender esse objetivo são usadas, como referência, pesquisas quantitativas "Preferência e Satisfação de Usuários de Shopping Centers de São Paulo" (PROJETO MY SHOPPING, TOLEDO \& ASSOCIADOS; 2004). Estas pesquisas, desenvolvidas especificamente para estudar hábitos de compras de consumidores de Shopping Centers, têm como complemento uma parcela dedicada ao estudo dos hábitos de compra desses consumidores em lojas localizadas em ruas de comércio. Seus resultados contêm indicadores relevantes, que permitem apontar as ruas comerciais que se destacam (onde compram); os produtos de preferência; quem compra (classe A, B, C ou D) e por que compra (conveniência, impulso).

As pesquisas contemplam cinco amostras quantitativas, domiciliares e probabilísticas de cada região da cidade de São Paulo - Norte, Sul, Leste, Oeste e Centro ${ }^{62}$ - das classes A, B, C e D, de acordo com o critério ABIPEME ${ }^{63}$. A metodologia, características da amostra, o questionário aplicado e demais informações relevantes para esta análise constam do Anexo A.

\section{1 - Locais de compra}

Na questão sobre outros locais de compra de roupa para uso pessoal afora Shopping Center, numa probabilidade de 0 a $100 \%, 87,4 \%$ dos entrevistados mencionam as lojas de rua. Ambulantes representam 7,5\%; shopping atacado, 4\%; sacoleiras, 2,9\% e nenhum, 11\% (gráfico 4.1.).

\footnotetext{
${ }^{62}$ Divisão regional da PMSP.

${ }^{63}$ Associação Brasileira dos Institutos de Pesquisa de Mercado (ABIPEME) define critérios de classificação socioeconômico do consumidor brasileiro, adotados por agências de pesquisa, propaganda e veículos de comunicação, obtidos em função de um conjunto de itens predeterminados (bens, escolaridade, renda etc.), cuja posse (ou não) indica a que classe socioeconômico pertence o entrevistado. A classificação das classes sócio-econômicas resulta de critério específico e de amostra colhida pelo Instituto de Pesquisa Toledo \& Associados e deve ter interpretações apenas no âmbito da probabilidade da mesma
} 


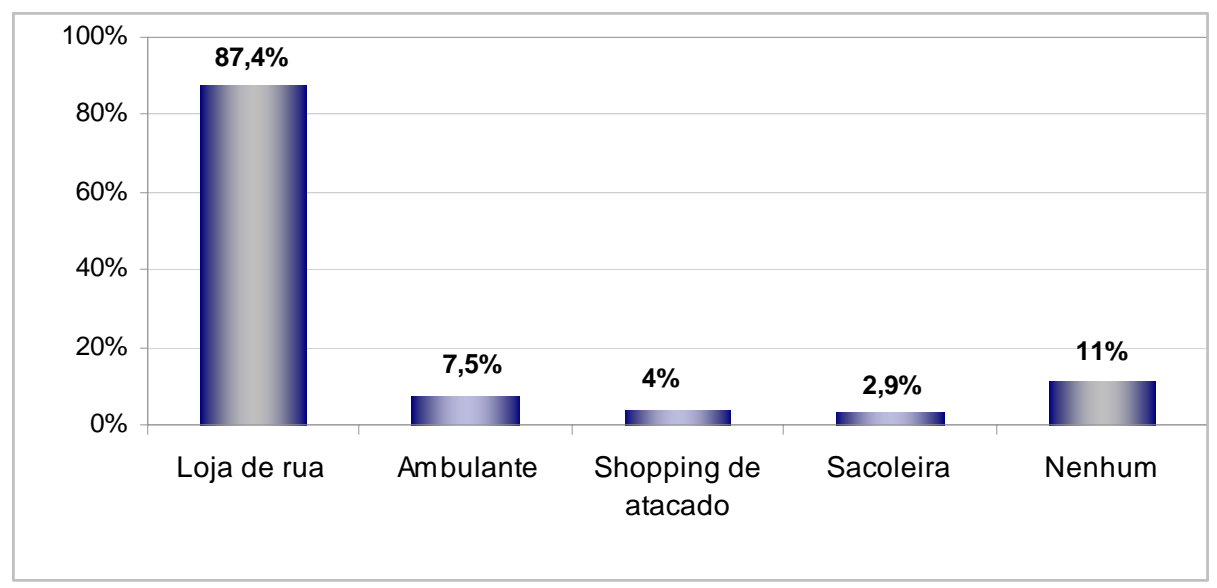

Gráfico 4.1: Outros locais de compra de roupa, respostas independentes. Fonte: Autora, com base em pesquisas da Toledo \& Associados, 2004.

Deve-se ressaltar, entretanto, que as classes A e B citam lojas de rua em menor proporção que as classes C e D (gráfico 4.2.). Quando desagregadas por classe sócio econômica (na probabilidade de 0 a 100\%), 93,8\% das respostas representam a classe D; $89,1 \%$, a classe C; $84,4 \%$, a classe B e $71 \%$, a classe A. A mesma dedução, ainda que com percentuais distintos, valem para ambulante, shopping de atacado e sacoleira. Respostas para "nenhum outro lugar", ou seja, compram apenas em shopping center; conclui-se que $24 \%$ dos entrevistados representam a classe A e 4,7\%, a classe D.

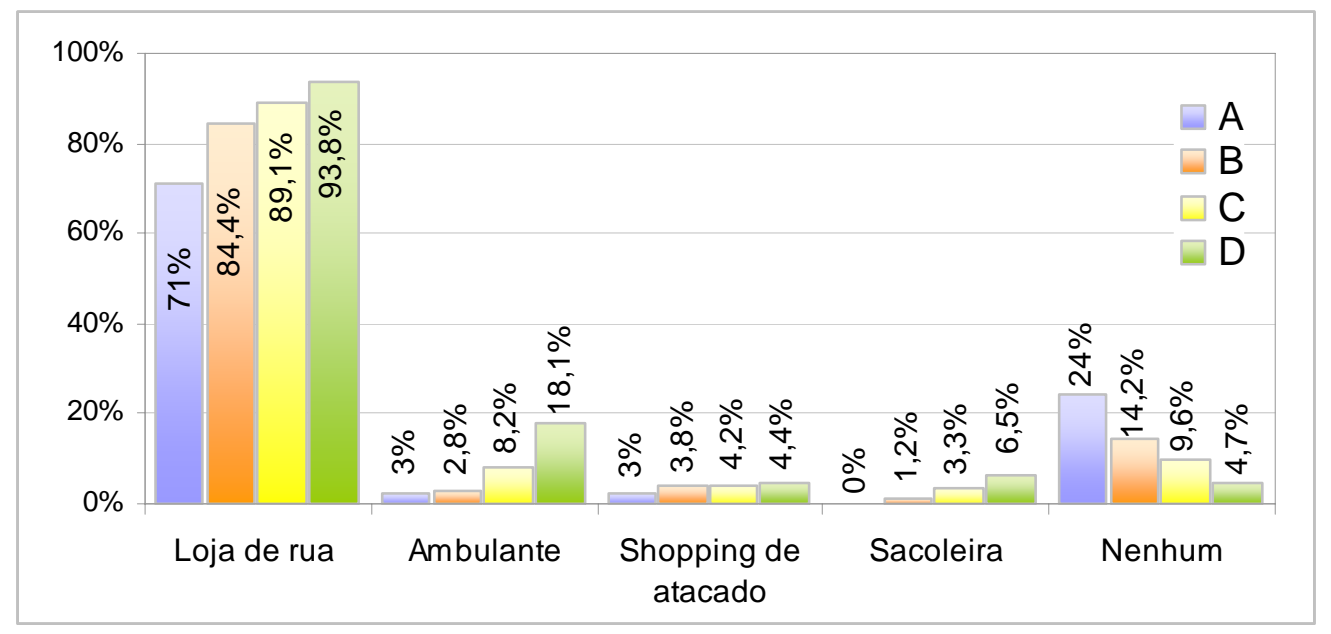

Gráfico 4.2: Outros locais de compra de roupa, por classe social. Índice de multiplicidade ${ }^{64}=2$.

Fonte: autora, com base em pesquisas da Toledo \& Associados, 2004.

64 O Índice de multiplicidade, constantemente citado nesta pesquisa, significa a média do número de respostas em que cada entrevistado cita mais do que um item alternativo, produto, local, etc. 


\section{2 - Produtos preferencialmente comprados em lojas de rua, além de roupas.}

Outros produtos preferencialmente comprados em lojas de rua, além de roupas, contempladas nos gráficos anteriores, são liderados por calçados com $57 \%$; seguidos por $45 \%$, que preferem comprar perfumaria / cosméticos; 29\%, que compram livros ou CDs; $26 \%$, eletroeletrônicos, 14\%, brinquedos; 5\%, jóias. Outras respostas, inferiores a 1\%, contemplando diversos produtos, representam 4\%. Nenhum produto de preferência representa $17 \%$ dos entrevistados.

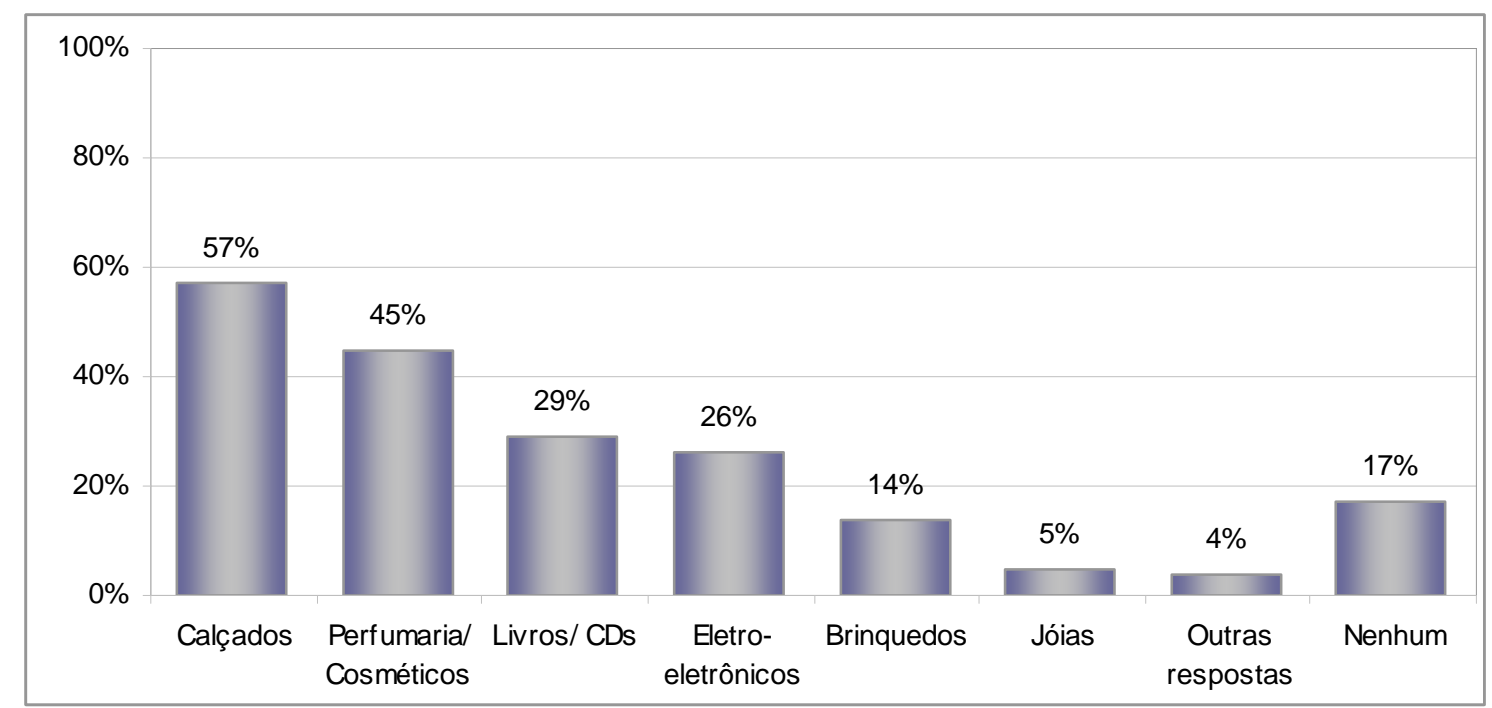

Gráfico 4.3 - Outros produtos preferencialmente comprados em lojas de rua, além de roupa. Probabilidade de 0 a $100 \%$ para cada resposta.

Em média, cada entrevistado citou 2,0 produtos comprados preferencialmente em lojas de rua. Índice de multiplicidade $=2$.

Fonte: Autora, com base em pesquisas da Toledo \& Associados, 2004.

As classes C e D são as que mais mencionam compra de calçados em lojas de ruas $(68 \%$ e $59 \%$, respectivamente). A classe B representa 53\% das respostas e a classe A, apenas $37 \%$ (gráfico 4.4). Perfumaria e cosméticos, também, são atribuídos em maior proporção à classe $\mathrm{D}$ $(50 \%)$ do que à classe $\mathrm{A}(33 \%)$. Quando o produto é livros/CD, existe equilíbrio nas respostas (27\%, classe A; 25\%, classe B; 32\%, classe C e 31\%, classe D). Quanto a nenhum produto de preferência, a situação é diferente: $30 \%$, classe A; $19 \%$, classe B; $16 \%$, classe C e $11 \%$, classe D. 


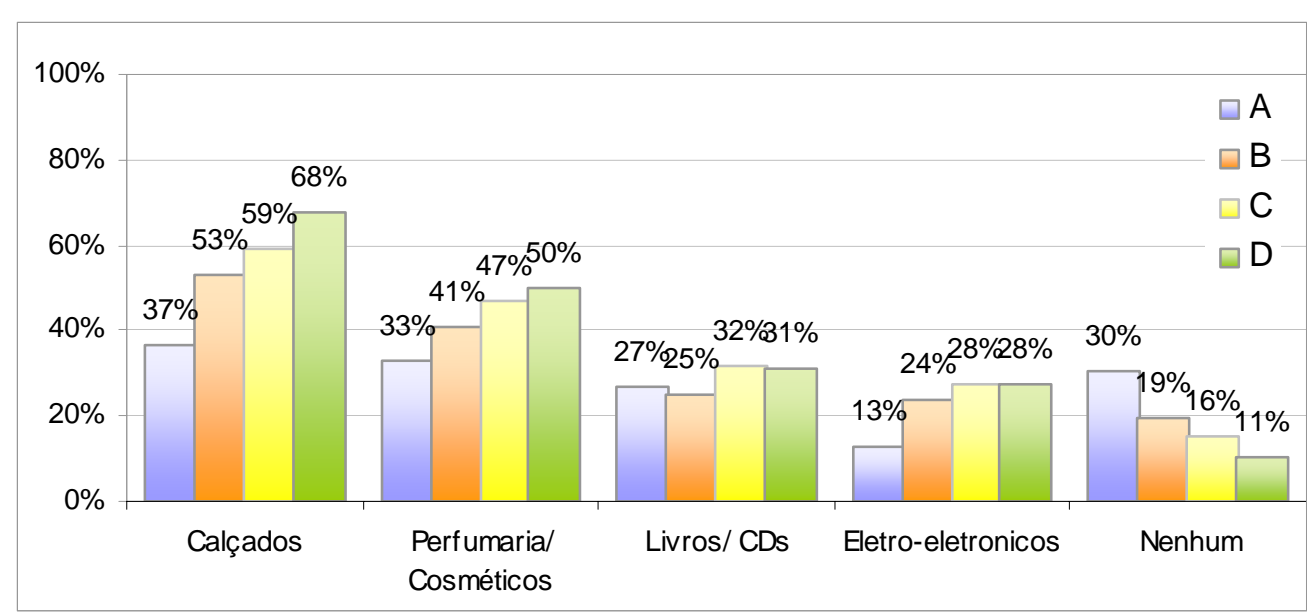

Gráfico 4.4. - Outros produtos preferencialmente comprados em lojas de rua, além da roupa, por classe sócioeconômica. Probabilidade de 0 a 100\% para cada uma das respostas. Índice de multiplicidade $=2$. Fonte: Autora, com base em pesquisas da Toledo \& Associados, 2004.

\section{3 - Ruas comerciais onde se compra regularmente}

São mencionadas, pelos entrevistados, 62 ruas da cidade de São Paulo, como locais de preferência para compras de roupas regularmente (Anexo 2). Serão demonstradas ruas com percentuais de citação acima de 5\%, critério que desconsidera, nesta análise, um total de 50 ruas de comércio dispersas na cidade de São Paulo, representadas por ruas de vizinhança ou subcentros menores e/ou em desenvolvimento.

A relação é liderada pela rua 25 de Março, citada por 28\% dos entrevistados. Em seguida vêm as ruas Doze de Outubro, com 14\%; Maria Marcolina, com 13\%; José Paulino, com 12\%, Teodoro Sampaio, com 11\%; Vinte e Quatro de Maio, Direita e Oriente (10\%, cada uma); Largo Treze ( $9 \%$ ) e Voluntários da Pátria, Silva Teles e Barão de Itapetininga (6\% cada uma) [ gráfico 4.5]. 


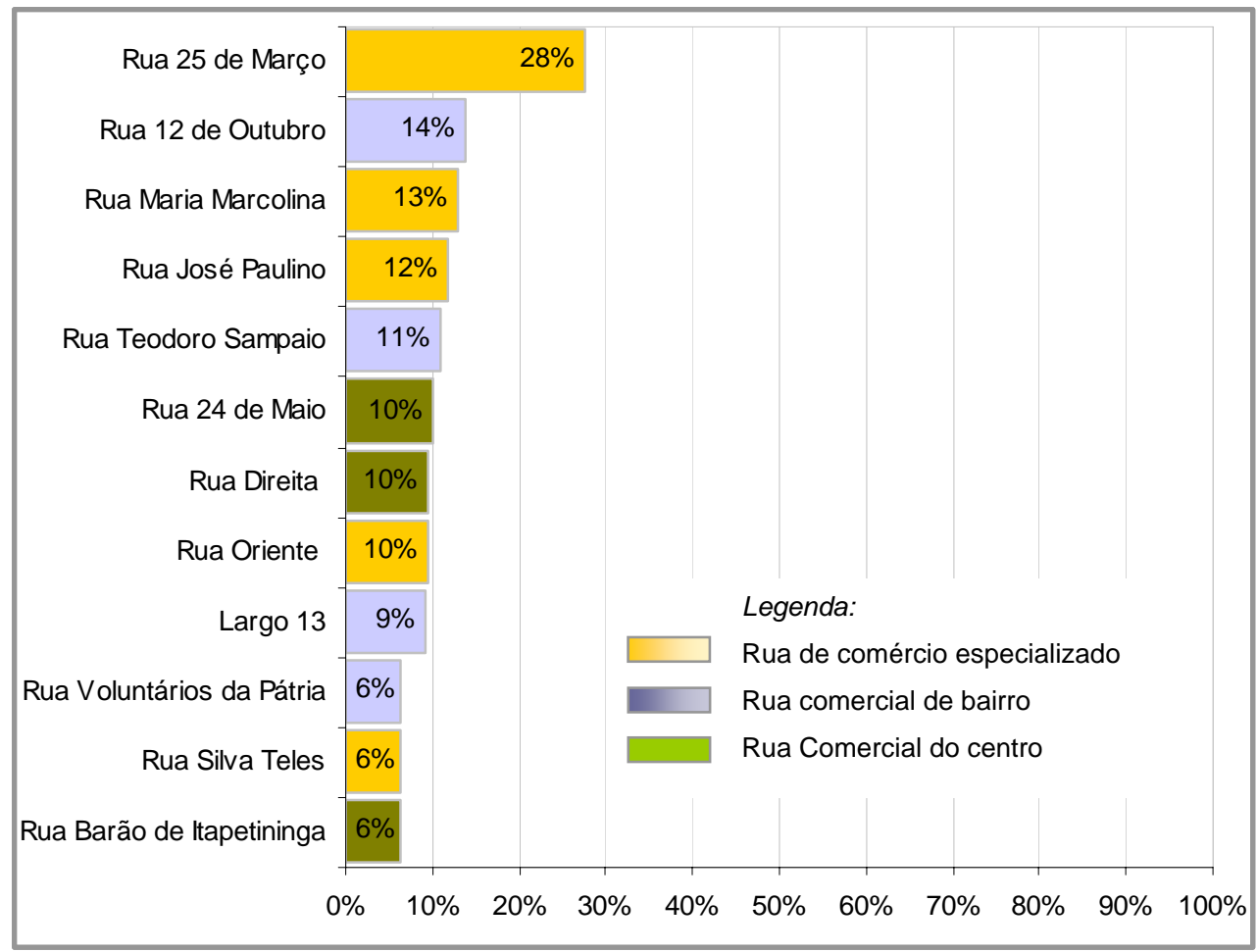

Gráfico 4.5 - Ruas comerciais onde compram roupas regularmente.

Probabilidade de 0 a $100 \%$ para cada rua. Respostas acumuladas acima de $5 \%$.

Índice de multiplicidade $=1,9$

Fonte: Autora, com base em pesquisas da Toledo \& Associados, 2004.

O gráfico mostra três tipos de ruas de comércio, de acordo com a conceituação utilizada no capítulo 1:

Ruas especializadas: Vinte e Cinco de Março, Maria Marcolina, José Paulino, Oriente e Silva Teles;

Ruas comerciais de Bairro, Doze de Outubro (Zona Oeste), Teodoro Sampaio (Zona Oeste) Largo Treze (Zona Sul) e Voluntários da Pátria (Zona Norte);

Ruas do centro tradicional : Vinte e Quatro de Maio, Barão de Itapetininga e Direita 


\subsection{1 - Ruas especializadas}

De acordo com os resultados da pesquisa considerada neste estudo, a rua Vinte e Cinco de Março atrai público de todas as idades, de todas as classes sociais e de todas as regiões, em proporções muito similares, ou seja, a área de influência é a cidade toda (Gráfico 4.6). Devese ressaltar que, no tocante às classes sociais, é a classe A que sobressai, com $33 \%$ dos entrevistados, das demais (26\%, classe B; $29 \%$ classe C; e 28\% classe D)

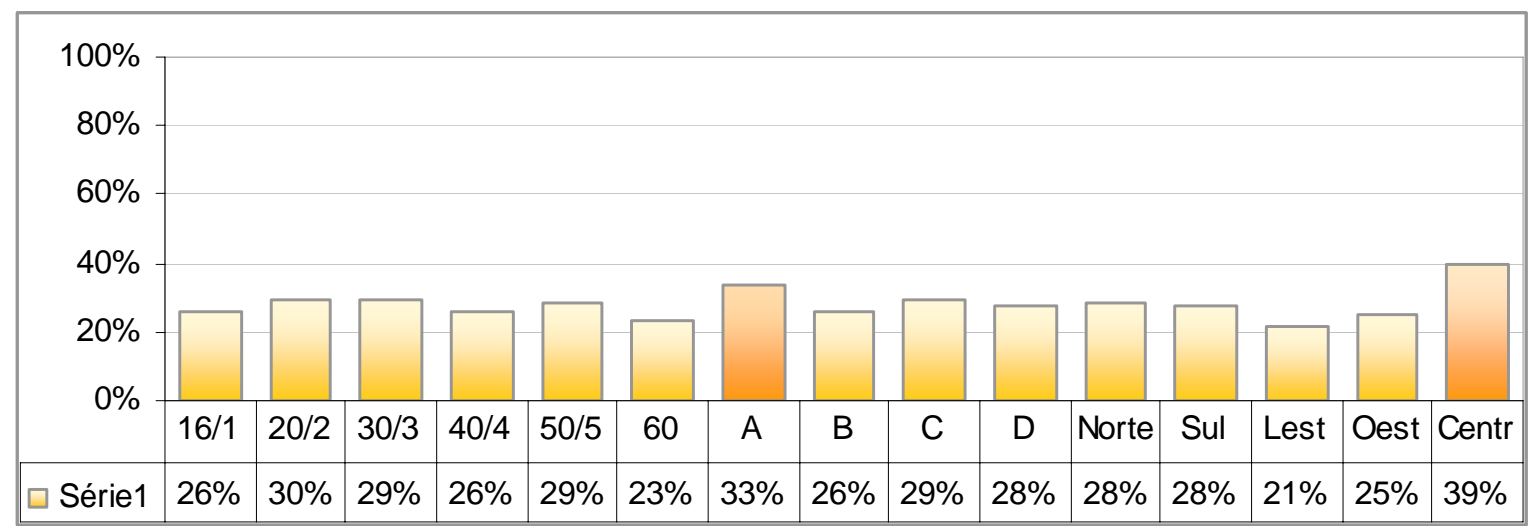

Gráfico 4.6 - Rua 25 de Março, por idade, por classe sócio-econômica e por regiões da cidade de São Paulo. Probabilidade de 0 a $100 \%$ para cada item.

Fonte: Autora, com base em pesquisas da Toledo \& Associados, 2004.

A rua Vinte e Cinco de Março constitui-se num fenômeno à parte. A região que começou como área comercial de tecidos e armarinhos,recentemente, passou a ter artigos diversificados e produtos de oferta sazonal, como, por exemplo: enfeites de Natal, festa junina, carnaval, contribuindo para um fluxo intenso e constante nesta região. Na avaliação de Felippe Naufel, presidente do Conselho de Ruas Comerciais da FECOMÉRCIO $\mathrm{SP}^{65}$, por comercializar produtos de baixo custo este pólo atrai não só a massa da população da Capital como também de outras cidades e até mesmo de outras regiões do país.

\footnotetext{
${ }^{65}$ Fonte: NAUFEL Felippe. Varejo de Rua Revigorado. Seminário GV CEV “Localização e expansão no Varejo Técnicas e Alternativas de Crescimento", FGV-EAESP. São Paulo, agosto de 2005.
} 
A rua José Paulino, bairro do Bom Retiro ${ }^{66}$, especializada em confecções, traz como informação relevante, as classes A e B, com 23\% e 15\%, respectivamente, representarem mais entrevistados que as classes C e D (10\% e 8\%, respectivamente) [Gráfico 4.7].

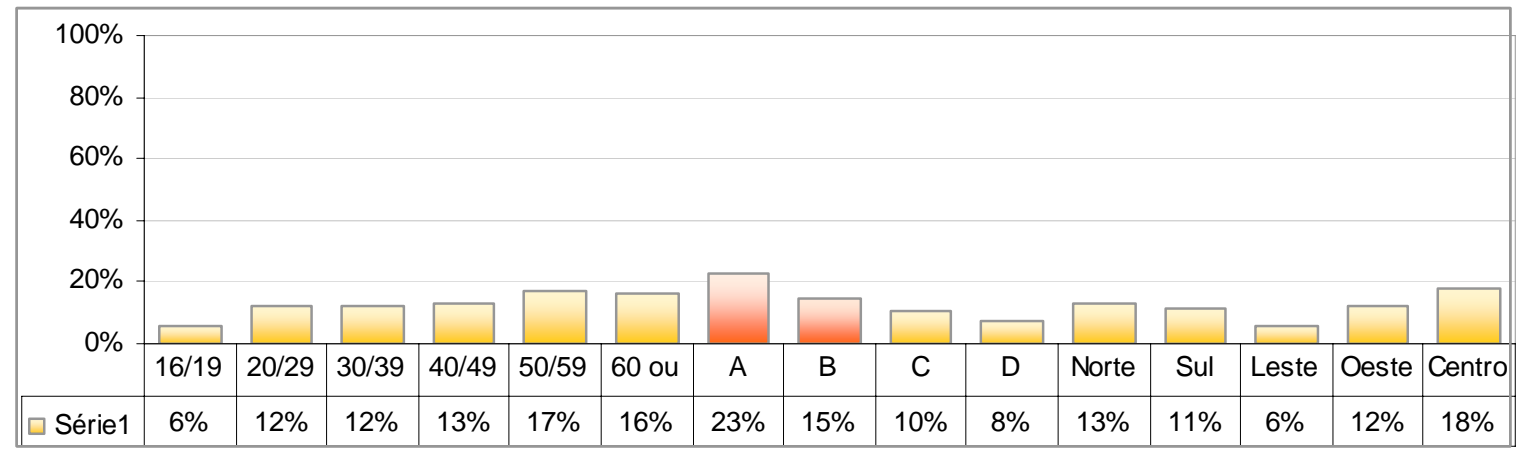

Gráfico 4.7 - Rua José Paulino, por idade, por classe social e por regiões da cidade de São Paulo. Probabilidade de 0 a $100 \%$ para cada item.

Fonte: Elaboração da autora, com base em pesquisas da Toledo \& Associados, 2004.

As informações da pesquisa confirmam interpretações da região feitas por AB'SABER (2004) e a tendência recente de transformação do antigo espaço de abastecimento de vestuário para as classes médias e populares em pólo produtor de moda para as classes altas. Esta característica traduz-se na sofisticação das vitrines das lojas e ao comércio da região não mais restrito à rua José Paulino, ter se expandido para ruas das adjacências, como a Professor Cesare Lombroso e a Aimorés, onde se instalaram lojas com vitrines arquitetonicamente comparáveis às de shopping centers.

A região da rua José Paulino não é restrita ao comércio varejista e tem como ponto forte de atração de lojistas de todo o Brasil o atacado, a venda em grande escala e a pronta-entrega.

\footnotetext{
${ }^{66} \mathrm{O}$ bairro do Bom Retiro é marcado pelo reduto de diferentes etnias que dominaram o comércio na sua história: colônias italianas, judaicas (em grande número no bairro, no final dos anos 30, em decorrência da Segunda Guerra Mundial), coreanas (a partir da década de 60 que passaram a comprar as principais lojas do bairro, sobretudo nos anos 80, quando se beneficiaram de uma lei de 1982, que anistiava imigrantes ilegais) e, mais recentemente, bolivianas, ligadas ao setor de vestuário (AB’SABER, 2004, p.141).
} 

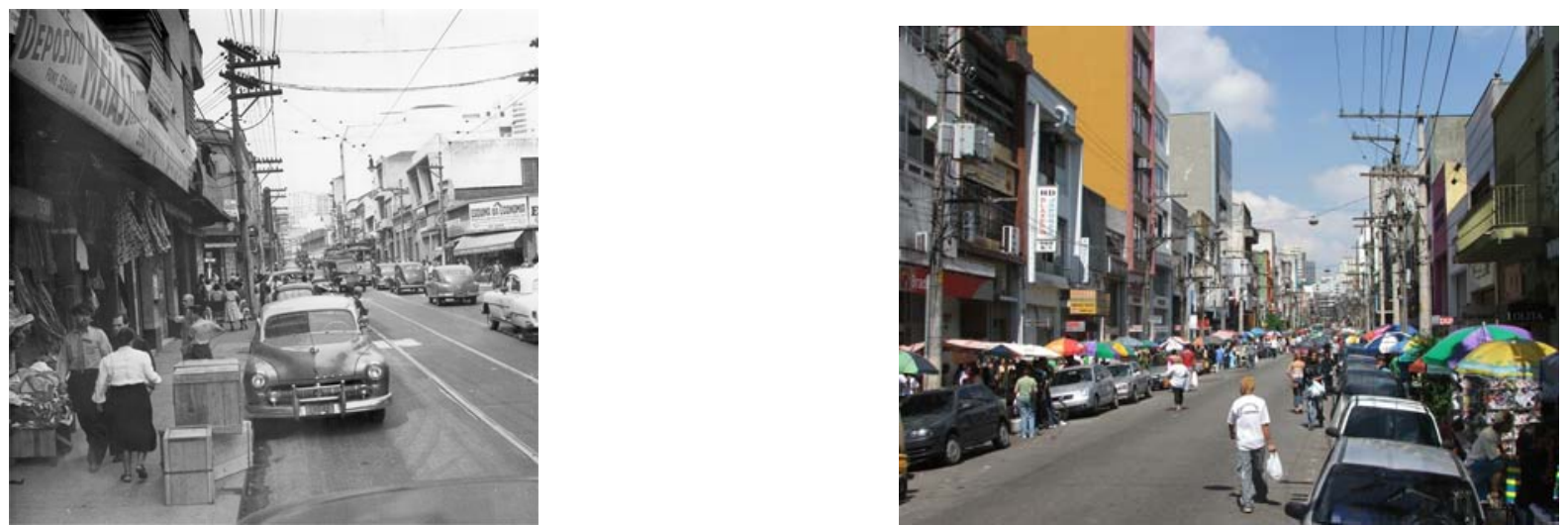

Foto 4.1: Rua José Paulino

Fonte: Folha imagem $<$ http://almanaque.folha.uol.com.br/saopaulo $>$, fev.2006

Foto 4.2: Rua José Paulino, Bom Retiro

Fonte: Autora, março, 2006
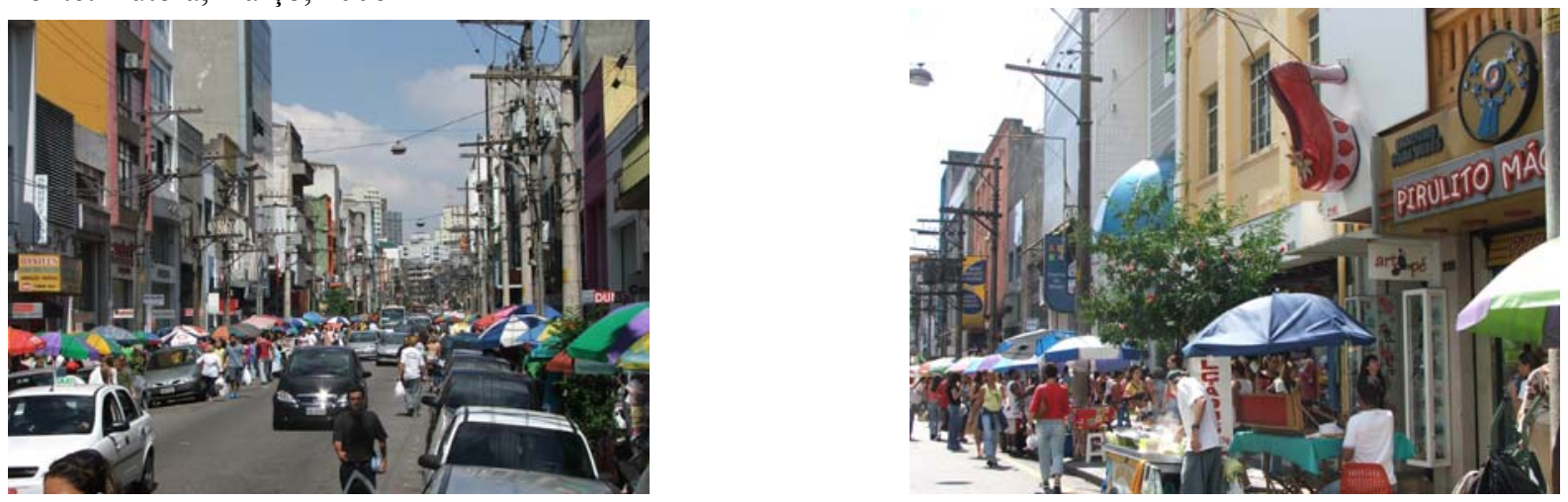

Foto 4.3: Rua José Paulino, Bom Retiro

Fonte: Autora, março, 2006

Foto 4.4: Rua José Paulino, Bom Retiro

Fonte: Autora, março, 2006
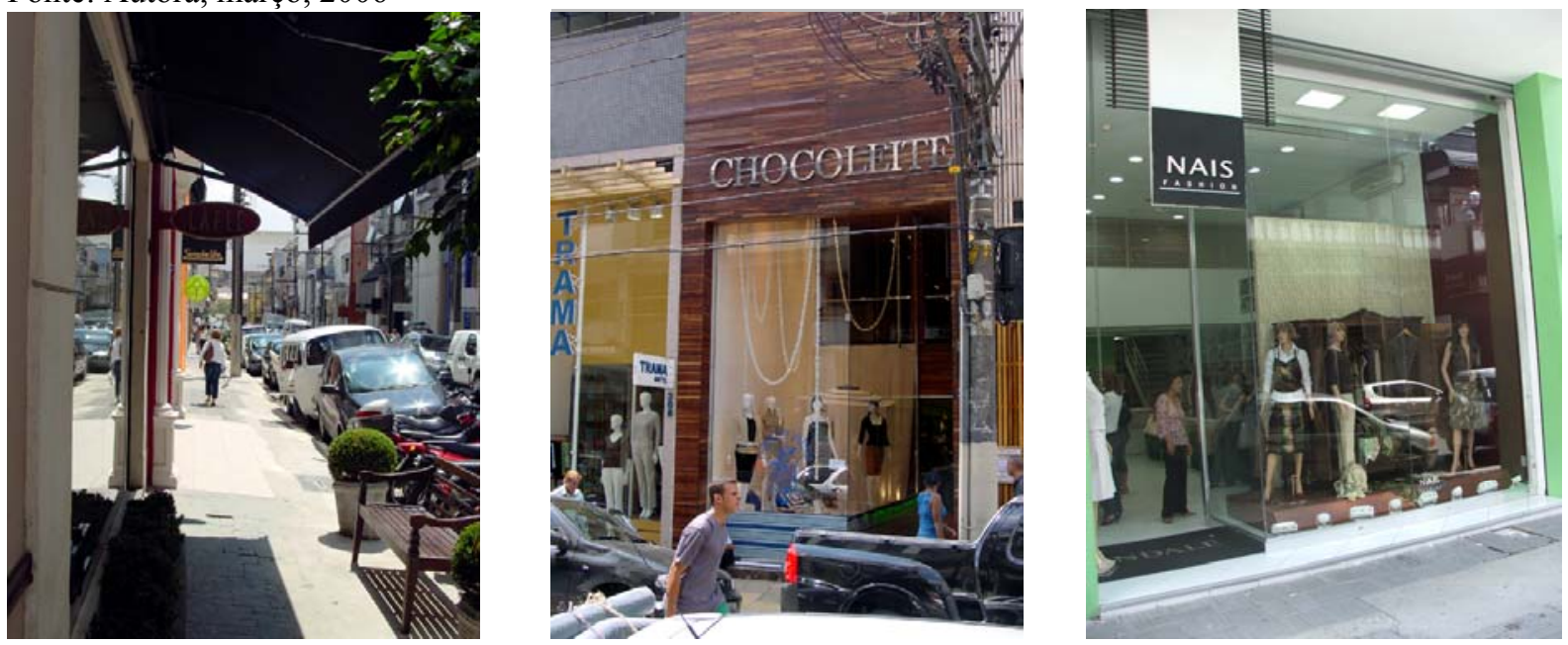

Foto 4.5: Rua Prof. Cesare Lombroso, Bom Retiro Fonte: Autora, março, 2006

Foto 4.6: Vitrine de Loja Rua Prof. Cesare Lombroso, Bom Retiro Fonte: Autora, março, 2006

Foto 4.7: Vitrine de Loja Rua Aimorés, Bom Retiro Fonte: Autora, março, 2006 
A rua Maria Marcolina, no Brás, zona Leste, compõe um núcleo especializado em atacado e varejo, juntamente com as ruas do Oriente e Silva Teles e, diferentemente da rua José Paulino, sua representatividade deve-se, na seqüência, às classes D (15\%), C (13\%) e B (12\%). O principal público é da própria zona Leste (27\%) [Gráfico 4.8].

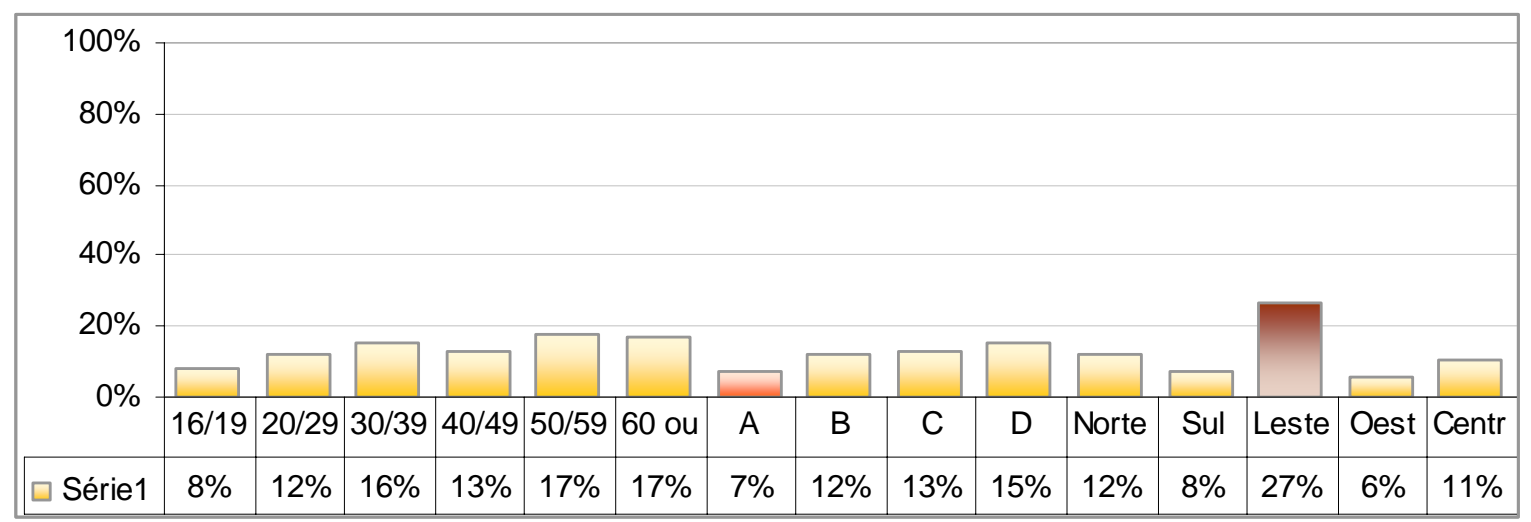

Gráfico 4.8- Rua Maria Marcolina, por idade, por classe social e por regiões da cidade de São Paulo. Probabilidade de 0 a $100 \%$ para cada item.

Fonte: Autora, com base em pesquisas da Toledo \& Associados, 2004.

\subsection{2 - Ruas comerciais de bairro (ou subcentros comerciais)}

A rua Doze de Outubro, embora localizada na zona Oeste, é mais freqüentada por pessoas vindas da zona Norte (31\%), seguida da freqüência de pessoas da própria zona Oeste $(26 \%)$ [Gráfico 4.9]. As classes D e C representam 16\% e 15\%, respectivamente, dos entrevistados, seguidas da classe B (11\%) e de apenas 7\% da classe A (Gráfico 4.9). Estes resultados se explicam pela sua localização e facilidade de transportes públicos (ônibus e trens), especialmente em relação aos distritos de Pirituba, Freguesia do Ó, São Domingos, Brasilândia, Perus e Jaraguá. A rua Voluntários da Pátria é um típico exemplo de rua de bairro regional, da qual beneficiam-se populações de bairros próximos (gráfico 4.9).

A rua Teodoro Sampaio tem a maior freqüência (41\%) registrada por entrevistados da própria zona Oeste, região em que está localizada. A classe A, na rua Teodoro Sampaio, é a mais representativa (28\%). A classe B vem a seguir, com 13\%; a classe $\mathrm{C}$, com $10 \%$ e classe $\mathrm{D}$, 
com 9\% . Este cenário é, comparativamente, inverso ao da rua Doze de Outubro e do Largo Treze (Gráfico 4.10). Este se justifica, provavelmente, pelo fato de tratar-se de uma rua diferenciada das demais pela sua grande extensão e a formação de três trechos distintos, que a caracterizam, além de um subcentro popular (nas imediações do Largo de Pinheiros), também, como uma rua especializada: em móveis (entre as avenidas Faria Lima e Henrique Schaumann) e em instrumentos musicais (após a Avenida Henrique Schaumann, em direção à Avenida Doutor Arnaldo).

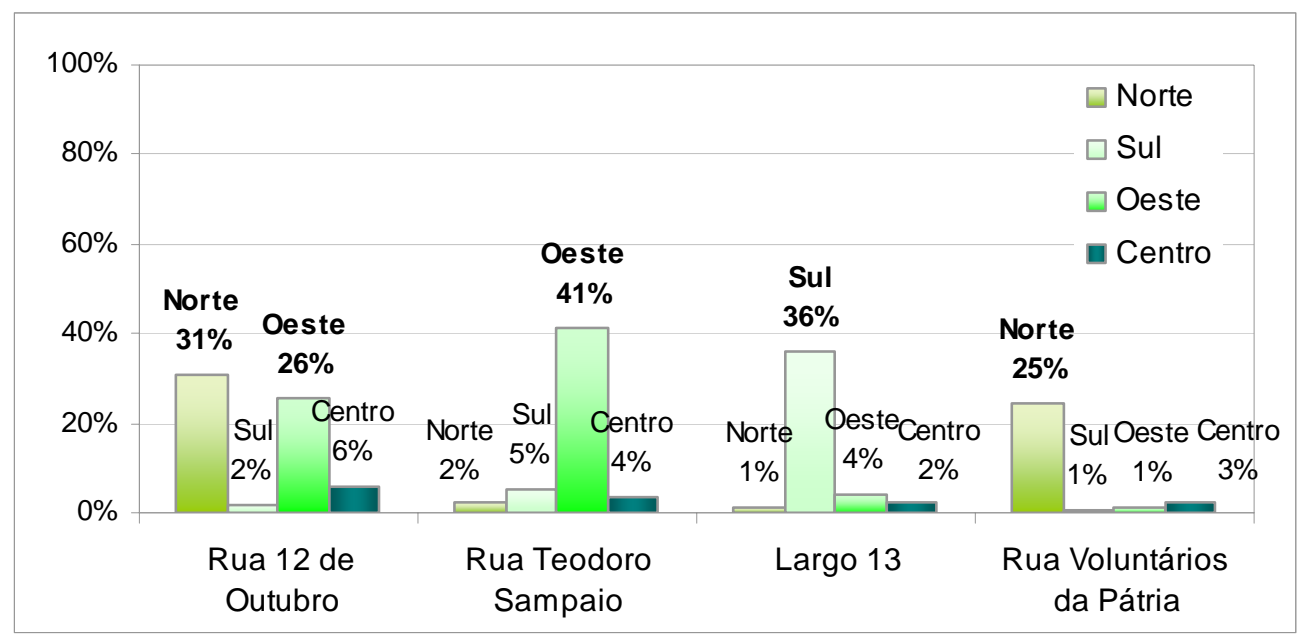

Gráfico 4.9 - Ruas comerciais de bairro, analisadas por regiões da cidade.

Probabilidade de 0 a $100 \%$ para cada item.

Fonte Autora, com base em pesquisas da Toledo \& Associados, 2004.

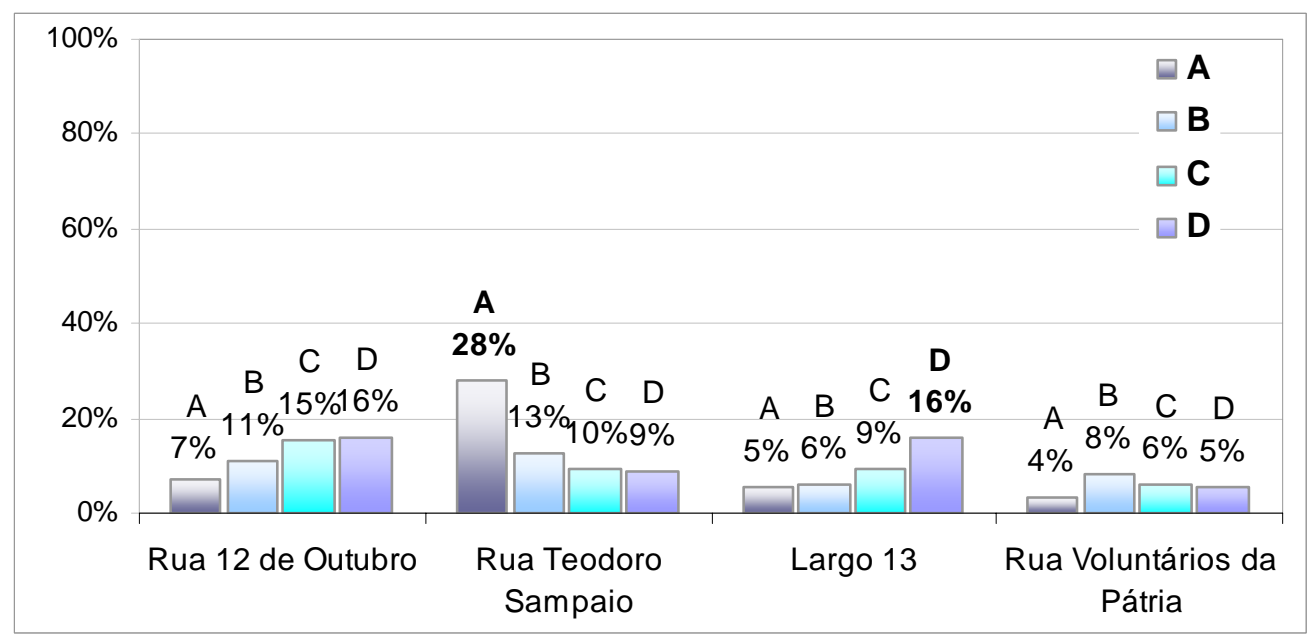

Gráfico 4.10 - Ruas comerciais de bairro, analisadas por classificação sócio-econômica. Probabilidade de 0 a $100 \%$ para cada item.

Fonte: Autora, com base em pesquisas da Toledo \& Associados, 2004. 


\subsection{3 - Ruas comerciais do centro tradicional}

Com relação às ruas comerciais do centro tradicional, destacam-se, na seqüência, a rua Vinte Quatro de Maio, a rua Barão de Itapetininga e a rua Direita. Cabe aqui, um destaque para a rua Vinte Quatro de Maio (gráfico 4.11), cujos entrevistados, nas comparações com as outras ruas comerciais do Centro, representam a mais jovem faixa etária, numa percentagem de $12 \%$ de jovens entre 16 e 19 anos, seguida de $14 \%$ e para a faixa de 20 a 29 anos e, se o enfoque for classe econômica, de 7\%, a classe $\mathrm{A}$, dados significativamente diferente da rua Barão de Itapetininga, gráfico 4.12, que conta apenas com 3\% de pessoas de 16 a 19 anos e $2 \%$ de classe A. A Galeria do Rock (antes, Grandes Galerias), “temática” como ponto de encontro de tribos urbanas, sede de um comércio diferenciado e que atrai o público jovem, é o grande diferencial da rua Vinte e Quatro de Maio em relação às demais do centro histórico. Quanto à rua Direita (Gráfico 4.13), cabe ressaltar as classes C e D (12\%, cada), seguidas da classe B $(6 \%)$ e classe A $(2 \%)$

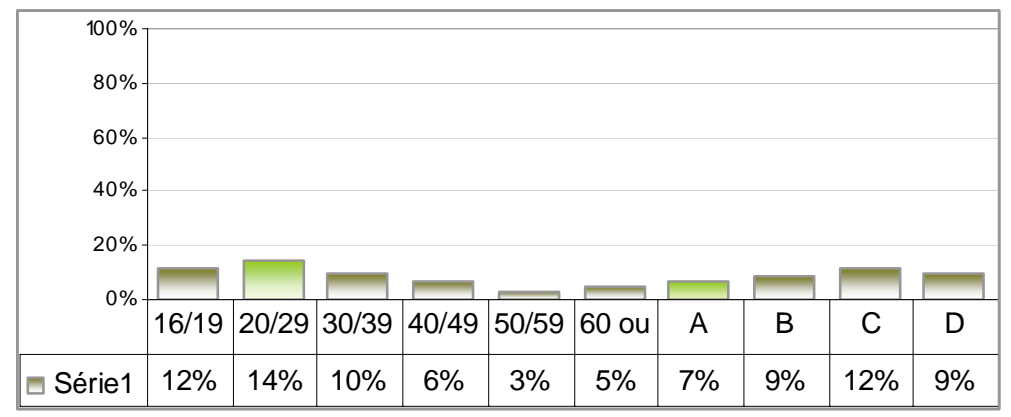

Gráfico 4.11 - Rua Vinte e Quatro de Maio, por idade e por classe sócio-econômica. Probabilidade de 0 a $100 \%$ para cada item.

Fonte: Autora, com base em pesquisas da Toledo \& Associados, 2004.

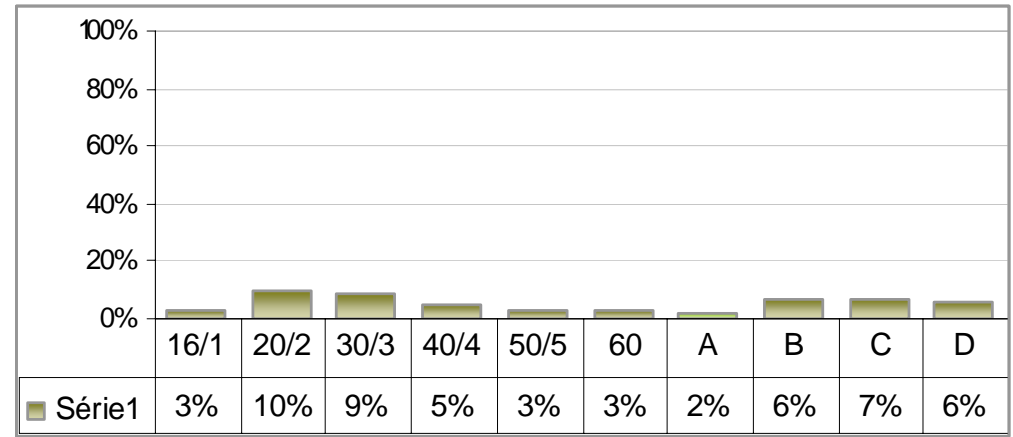

Gráfico 4.12- Rua Barão de Itapetininga por idade e por classe sócio-econômica. Probabilidade de 0 a $100 \%$ para cada item.

Fonte: Autora, com base em pesquisas da Toledo \& Associados, 2004. 


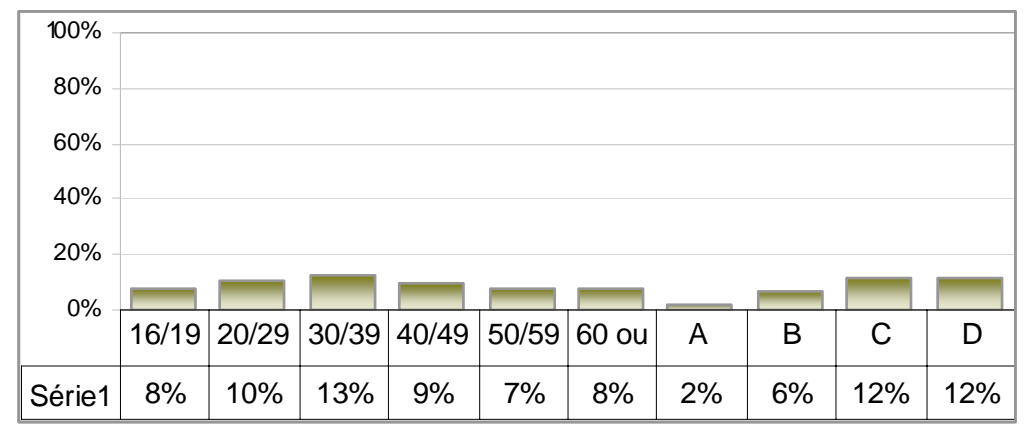

Gráfico 4.13- Rua Direita, por idade e por classe sócio-econômica. Probabilidade de 0 a $100 \%$ para cada item.

Fonte: Autora, com base em pesquisas da Toledo \& Associados, 2004.

\section{4 - Razões da preferência pelas lojas de rua}

Nas avaliações dos consumidores entrevistados que informaram fazer compras em lojas de rua, $82 \%$ acreditam e justificam comprar em lojas de rua pela prática de "preços mais baratos", ou 58\% em relação ao total das respostas (Gráfico 4.14). Esta convicção, entretanto, segundo o levantamento, tem diferença entre as classes sociais [Gráfico 4.15].

Como segundo motivo, está a "compra por impulso", com 24\% (ou 16\% do total) dos entrevistados. As pessoas estão nas ruas, durante a semana, mais tempo do que estão nos Shoppings Centers. Esta convicção aparece de forma diferente entre as classes sociais [Gráfico 4.15].

A terceira razão é a proximidade do lar com 17\% (ou 12\% do total) dos entrevistados, ou seja, a área de influência, que beneficia as lojas de rua próximas às residências (Gráfico 4.14). A variedade de opções de produto é mencionada por $9 \%$ (6\% do total) dos entrevistados e a variedade de lojas por 5\% (3\% do total). Ter conta-crediário nas lojas de rua, embora com apenas 3\% dos registros, pouco expressivo, vale acrescentar a maior importância para a classe (Gráfico 4.15). 


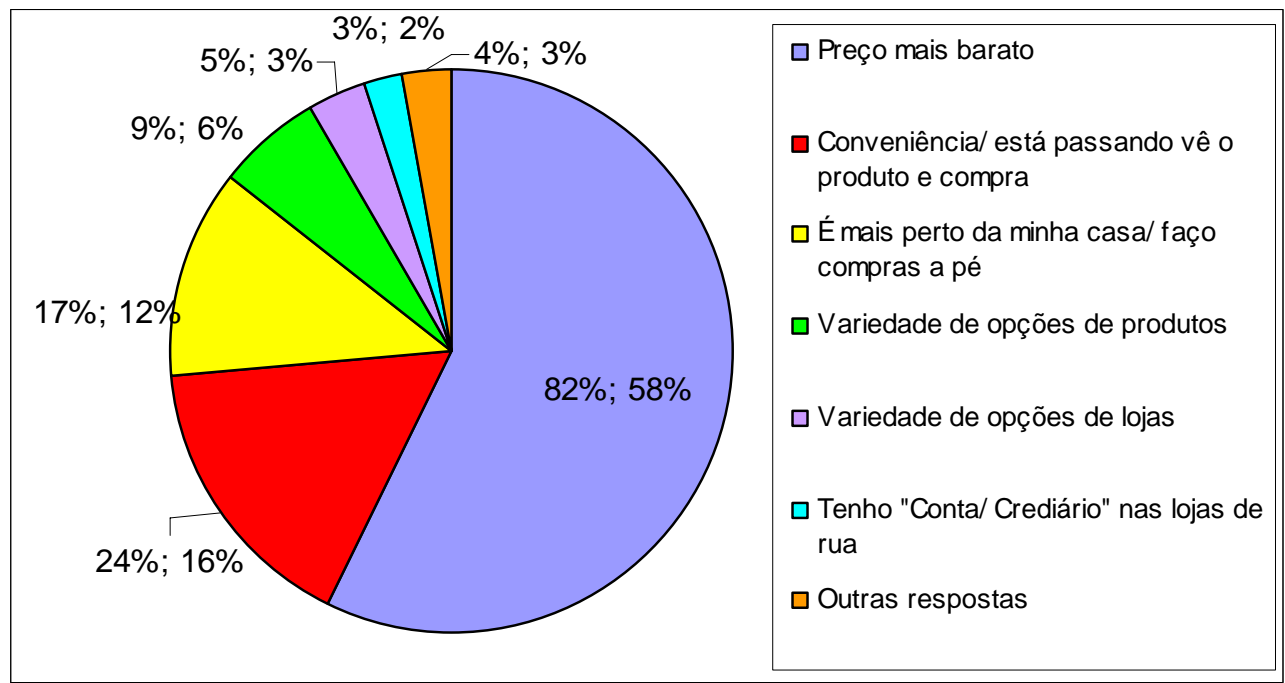

Gráfico 4.14 - Razões de preferência pelas lojas de rua.

Em média, cada entrevistado citou 1,4 razões (índice de multiplicidade $=1,4$ ).

Fonte: Autora, com base em pesquisas da Toledo \& Associados, 2004.
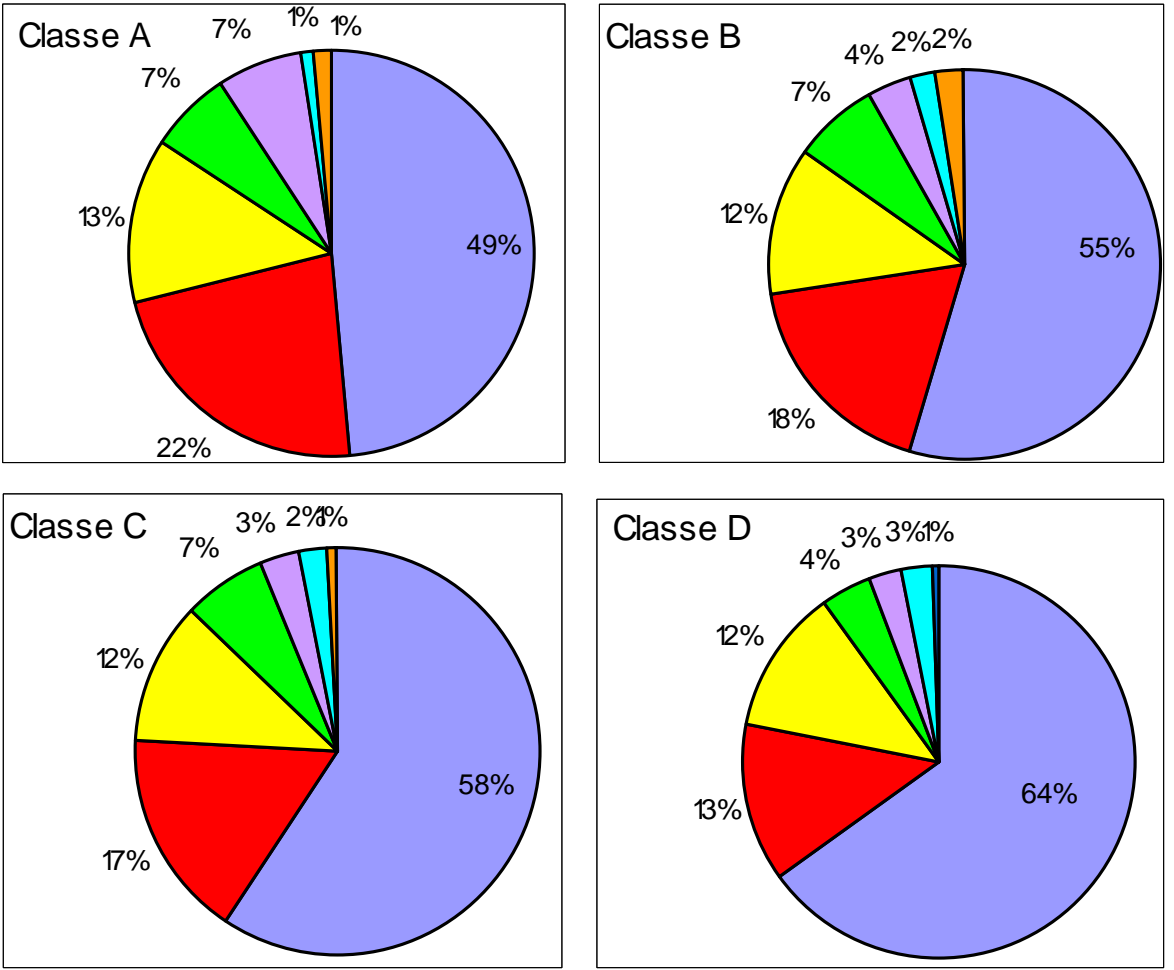

\section{Legenda}

$\square$ Preço mais barato

口 Conveniência/ está passando vê o produto e compra

$\square$ É mais perto da minha casa/ faço compras a pé

$\square$ Variedade de opções de produtos

$\square$ Variedade de opções de lojas

口 Tenho "Conta/ Crediário" nas lojas de rua

$\square$ Outras respostas

Gráfico 4.15. - Razões de preferência pelas lojas de rua, por classe sócio-econômica.

Fonte: Autora, com base em pesquisas da Toledo \& Associados, 2004. 


\section{5 - Ruas Classe A}

É perceptível que as ruas de comércio destacadas até o momento têm representatividade para as classes populares, porque estas vias se constituem nos principais subcentros populares da cidade de São Paulo, apesar de nestas ruas ter sido verificado, constantemente, entrevistados da classe $\mathrm{A}^{67}$. Há necessidade, portanto, de fazer distinção, de ruas que representariam a classe A, de acordo com esta pesquisa. Pela tabela 4.1, as ruas mais citadas pelos entrevistados, são a Augusta, a João Cachoeira e a Oscar Freire. Nesta tabela, é importante destacar a rua Silva Bueno que contempla entrevistados da zona Sul e a rua Prof. Afonso Bovero, da zona Oeste.

\begin{tabular}{|c|c|c|c|c|c|c|c|c|c|c|}
\hline \multirow{3}{*}{ Variáveis } & Total & \multicolumn{4}{|c|}{ Classe Abipeme } & \multicolumn{5}{|c|}{ Região da cidade } \\
\hline & $\%$ & \multicolumn{4}{|c|}{$\%$} & \multicolumn{5}{|c|}{$\%$} \\
\hline & & A & B & C & D & Norte & Sul & Leste & Oeste & Centro \\
\hline Base $N^{\circ}$ (Abs.) & 1876 & 57 & 652 & 865 & 302 & 421 & 398 & 392 & 395 & 270 \\
\hline Rua Augusta & $0,9 \%$ & $8,8 \%$ & $1,7 \%$ & & & $0,2 \%$ & $1,3 \%$ & & $1,5 \%$ & $1,5 \%$ \\
\hline Rua João Cachoeira & $0,6 \%$ & $7,0 \%$ & $0,9 \%$ & $0,1 \%$ & & & $2,0 \%$ & & $0,5 \%$ & $0,4 \%$ \\
\hline Rua Oscar Freire & $0,6 \%$ & $5,3 \%$ & $1,2 \%$ & & & $0,2 \%$ & $1,0 \%$ & & $1,0 \%$ & $0,7 \%$ \\
\hline Rua Silva Bueno & $1,0 \%$ & $3,5 \%$ & $1,2 \%$ & $0,9 \%$ & & & $4,0 \%$ & $0,5 \%$ & & \\
\hline $\begin{array}{l}\text { Rua Prof. Afonso } \\
\text { Bovero }\end{array}$ & $0,5 \%$ & $3,5 \%$ & $0,6 \%$ & $0,3 \%$ & & & & & $2,3 \%$ & \\
\hline Rua Pamplona & $0,4 \%$ & $1,8 \%$ & $0,9 \%$ & $0,1 \%$ & & & $1,5 \%$ & & $0,5 \%$ & \\
\hline Av. Paulista & $0,3 \%$ & $1,8 \%$ & $0,6 \%$ & & & & & & $1,0 \%$ & $0,4 \%$ \\
\hline
\end{tabular}

Tabela 4.1 - Ruas Classe A

Fonte: Autora, com base em pesquisas da Toledo \& Associados, 2004.

\footnotetext{
${ }^{67}$ A amostra correspondente à classe A representa 52 do total de 1876 entrevistados (tabela Anexo 1).
} 


\section{5 . ESPECIFICIDADES DE UMA RUA DE COMÉRCIO}

Nos capítulos anteriores, a dinâmica do comércio na cidade de São Paulo foi estudada sob três diferentes aspectos - pela evolução urbana, pelas transformações sócio-econômicas e pelos hábitos de compra do consumidor - que, no conjunto, se complementam e formam a base para entendimento da dinâmica da rua de comércio no âmbito geral.

Neste capítulo, o objetivo é buscar algumas evidências empíricas através das especificidades de uma rua de comércio, no sentido de reforçar o quadro geral desenhado para o comércio varejista na cidade de São Paulo.

Nada mais adequado para obter estas evidências do que retomar o significado da variedade equilibrada (ou mix de lojas) de um subcentro tradicional, alcançada pelas forças do mercado (Villaça 1998, p.303).

Para isso, primeiro, serão consideradas transformações decorrentes de um início de processo de revitalização de ruas de comércio, fato recente e influenciante na discussão seguinte.

\section{1 - Transformações recentes - revitalização de ruas comerciais}

As atividades caracterizadas pelo comércio, principalmente a dos pequenos estabelecimentos independentes, que identificam as ruas de comércio tradicional de São Paulo, enfrentam problemas de degradação urbana desde as últimas décadas do século $\mathrm{XX}$, devido a diversos fatores sócio-econômicos e, entre tantos outros, o surgimento de grandes redes de varejo concentradoras da atividade comercial, como shopping centers e hipermercados, que trouxeram consigo mudanças de hábitos de consumo, quanto ao local e à forma de efetuar as compras. 
A tentativa de reversão deste quadro se manifestou, efetivamente, com as primeiras iniciativas concretas da Prefeitura do Município de São Paulo através do Programa de Intervenção em Ruas Comerciais do Município de São Paulo instituído pelo Decreto no. 42.834 de 06 de fevereiro de 2003 e consolidado pela Lei 14.003/2005, que buscou, em conjunto com as associações de comerciantes, realizar melhoramentos dos espaços públicos a favor do varejo de rua, consistentes, basicamente, de novo calçamento, melhoria na acessibilidade ao pedestre, implantação de paisagismo, comunicação visual e mobiliário urbano, além de esquemas de segurança.

A rua João Cachoeira, no bairro do Itaim Bibi (Zona Oeste) ${ }^{68}$, foi o primeiro projeto aprovado pela Comissão de Implementação de Intervenções em Ruas Comerciais do Município de São Paulo (COMIRC) criada pelo decreto 42.834/03 e teve suas obras inauguradas em dezembro de 2003. A rua que hoje se autodenomina de "shopping a céu aberto", passou por modificação no calçamento, reforço paisagístico e rampas para acesso de deficientes físicos. O presidente da Associação dos Lojistas da rua João Cachoeira, Felippe Naufel, explica que as alterações, feitas com base em uma pesquisa realizada com o consumidor local, tiveram por objetivo aumentar a atração de consumidores de classes A e B, moradores dos arredores, e das pessoas que trabalham na região, tendo sido atingido logo no primeiro ano, quando se avaliou que as vendas de Natal de 2003 cresceram, em média, 19,4\% em relação a igual período de $2002 .{ }^{69}$

As experiências positivas da rua João Cachoeira ${ }^{70}$ e os efeitos também, supostamente, positivos de parceria entre Prefeitura e lojistas se transformaram no modelo para outras ruas da cidade, como, por exemplo, a rua Joaquim Nabuco (Zona Sul) e rua Vinte e Cinco de Março (Centro), cujas obras foram concretizadas em 2004 e 2005, respectivamente.

\footnotetext{
${ }^{68}$.Havia, no ano de 2003, uma lista com 70 ruas aguardando aprovação de projetos.

${ }^{69}$ Rua do Itaim-Bibi é a única que já colhe frutos do projeto. Diário do Comércio, 15/11/2004.

${ }^{70}$ Prefeitura e Lojistas Dividirão Gastos com Recuperação de Ruas. Diário do Comércio, 15/06/2005.
} 
A rua Oscar Freire, nos Jardins, em plenas obras no momento, também faz parte desta parceria e tem previsão para inauguração neste ano de 2006. O grande diferencial da rua Oscar Freire em relação às demais ruas citadas é a noticiada parceria com a American Express $(\text { Amex })^{71}$, empresa de cartões de crédito, mediante patrocínio de parte das obras que permitiram o aterramento de todo cabeamento externo o que não foi possível executar, por exemplo, nas ruas João Cachoeira e Joaquim Nabuco.

Estas primeiras experiências de revitalização se deram em ruas de público pertencente às classes de alta renda ${ }^{72}$ e na rua Vinte e Cinco de Março, que possui uma condição atípica no mercado. A parceria entre Prefeitura e Associação de Lojistas, que, atualmente, também conta com o apoio e adesão da Federação do Comércio de São Paulo (FECOMERCIO), passa a incluir ruas de comércio de baixa renda, sendo que, a rua Doze de Outubro, na Lapa (zona Oeste), foi a primeira, com estas características, a fazer parte do programa de revitalização ${ }^{73}$.

Trata-se de um modelo que busca fornecer novas formas de conforto e estão em sintonia com tendências internacionais. Balsas ${ }^{74}$ (2000) aponta conjuntura semelhante em Portugal, tendo a experiência estrangeira demostrado que os casos de revitalização de centros urbanos com sucesso passaram, na sua grande maioria, por parcerias efetivas entre setores público e privado.

\footnotetext{
${ }^{71}$ Associação Brasileira de Cartões de Crédito (ABECS). "Obras da Oscar Freire recomeçam dia 2". Artigo 19/01/2006.

${ }^{72}$ Segundo secretário de Coordenação das Subprefeituras, os projetos de revitalização de ruas comerciais e de padronização de calçadas devem ser realizados não só nas áreas nobres, como a Rua Oscar Freire, mas também em outras áreas da cidade Fonte: PREFEITURA DA CIDADE DE SÃO PAULO: Prefeitura Finaliza $1^{a}$. Fase das Obras de Revitalização da Rua Oscar Freire. Notícias: 01/12/2005.

73 "Protocolo de Intenções Para Revitalização da Rua 12 de Outubro, no Âmbito do Programa de Requalificação de Ruas Comerciais", entre a Prefeitura Municipal de São Paulo e a Associação dos Comerciantes, Proprietários e Empreendedores da Lapa, assinado em 22 de setembro de 2005.

${ }^{74}$ Para maiores detalhes sobre as principais estratégias de intervenção em ruas comerciais como "Business Improvement Districts" - BIDs, ou Áreas de Desenvolvimento Econômico e o "the Main Street Program", ou o Programa da Rua Central, nos Estados Unidos e "Town Centre Management Schemes" (mecanismos de Gestão do Centro da Cidade) no Reino Unido ver BALSAS, Carlos José Lopes. O Urbanismo Comercial e as Parcerias Público-Privado para a Gestão do Centro das Cidades, Ensinamentos da Experiência Estrangeira, Sítio Observatório do Comércio. 2000.
} 
O impacto positivo possível de mensurar, no momento, é a própria mobilização do setor público e do setor privado neste processo de parceria para revitalização das ruas comerciais iniciado em 2003, bem como a sua continuidade, através da adesão de associações de lojistas representantes de diversas regiões e perfis sócio-econômicos. De acordo com Naufel (2005), das trinta e uma Subprefeituras da cidade, 26 apresentaram projetos para revitalização no ano de 2005 .

\section{2 - A rua de comércio}

Retomados os conceitos de Villaça (1998, p.303) segundo os quais "o poder estruturador (ou polarizador) dos centros tradicionais (principais ou subcentros) possa ser atribuído à "variedade equilibrada" de comércio e serviço, variedade esta, que é alcançada pelas forças do mercado, é plausível a hipótese de que uma rua de comércio que tenha capacidade de atrair o consumidor deva possuir um mix de lojas que efetivamente guardem estas características.

Consideradas as etapas anteriores deste estudo, pode-se afirmar que a rua Doze de Outubro, localizada no bairro da Lapa, zona Oeste de São Paulo, se destacou como a rua de bairro (ou subcentro tradicional) mais citada nas entrevistas da pesquisa quantitativa sobre hábitos de compras e, por isso, foi escolhida para o levantamento do citado mix de lojas.

Pólo urbano e elo de ligação entre bairros e municípios da Zona Oeste, o bairro da Lapa teve seu desenvolvimento ligado à implantação das ferrovias e, subseqüentemente, das indústrias. De pequeno núcleo populacional formado por trabalhadores das olarias e por agricultores das propriedades rurais, nas últimas décadas do século 19, a região da Lapa, antes da chegada do século 20, passara por mudanças significativas. Sítios e fazendas são transformados por seus proprietários em grandes loteamentos. Em 1912, a Companhia City loteou, arborizou e arruou o Alto da Lapa. De acordo com SANTOS (1980, p.115) a chegada da Estrada de Ferro São Paulo Railway inaugurada em 1867 e o surgimento de fábricas no início do século XX, 
transformariam a Lapa em um bairro urbano, com intensa vida social e econômica que proporcionaram a configuração do simples arruamento suburbano em núcleo comercial.

Com a chegada dos bondes, que vinham do Centro até a rua Guaicurus (ponto onde a rua Doze de outubro se inicia), desenvolve-se o comércio na Lapa de Cima, a parte alta do bairro. Conforme a ferrovia avançava, o comércio tomava impulso na rua Doze de Outubro e arredores. Em 1908, o bairro já ostentava a importante Cooperativa de Consumo, na mencionada rua Doze de Outubro. Situado na rota de São Paulo-Campinas, com a inauguração da rodovia Anhangüera, em 24 de janeiro de 1943, o bairro sofreu grandes transformações, acelerando-se o seu crescimento comercial (SANTOS, 1980, p.123).

No início da década de 1950, a rua Doze de Outubro, ao mesmo tempo em se destacava por suas lojas de tecidos finos e armarinhos, começavam as preocupações com o avanço do comércio informal na região ${ }^{75}$. Em 1954 foi inaugurado o Mercado Distrital da Lapa e, em 1968, o Shopping Center Lapa ${ }^{76}$.

Com essas características, a rua Doze de Outubro, típica rua comercial de bairro, é caracterizada, neste trabalho, como um centro comercial não planejado resultado de um conglomerado varejista que teve formação e evolução espontânea.

Formada por seis quarteirões, inicia-se na no cruzamento da rua Guaicurus com a rua John Harrison, nas proximidades do Mercado da Lapa e do acesso subterrâneo à estação Lapa da Companhia Paulista de Trens Metropolitanos (CPTM) e segue até a rua Barão de Jundiaí (via

\footnotetext{
${ }^{75}$ Encontra-s registrada, na Ata da Primeira Reunião da Diretoria Distrital da Lapa da Associação Comercial de São Paulo, em 9 de Janeiro de 1952, a necessidade de uma campanha para extinção desse comércio [...] "que além de dar ao bairro um aspecto de feira livre, representava uma desleal concorrência ao comerciante regular" (Distrital Lapa 50 anos, p 80).

${ }^{76}$ O Shopping Center Lapa, segundo da capital, foi inaugurado por Alfredo Mathias, com os mesmos conceitos do Shopping Center Iguatemi, destinado à classe de alta renda, mas não teve o êxito esperado, principalmente pela alta concentração de transportes coletivos (trens suburbanos e ônibus metropolitanos) no entorno. Atualmente ele se integra ao comércio popular da região.
} 
intermediário de ligação entre a Rodovia Anhanguera e centro da cidade. O fluxo intenso de pedestres, facilitado pela existência de transporte público abundante por ônibus e trens, sempre foi uma das características do comércio local, que não está restrito apenas à citada rua Doze de Outubro, mas representado também por outras ruas da circunvizinhança, como a Cincinato Pomponet, a Clemente Álvares, a Nossa Senhora da Lapa (SANTOS, 1980).

A posição geográfica do bairro tornou-se um dos pontos principais para bairros da zona norte e oeste, como Pirituba, Perus Caieiras, Francisco Morato, Franco da Rocha, Osasco, Barueri, Jandira, Carapicuíba e Freguesia do Ó (esta fora da orla ferroviária). Isto faz com que a área de influência do comércio da rua Doze de Outubro ultrapasse os limites do bairro da Lapa e se expanda para os da zona norte e oeste, inclusive cidades circunvizinhas, cujos acessos são facilitados pela rede de transportes públicos.

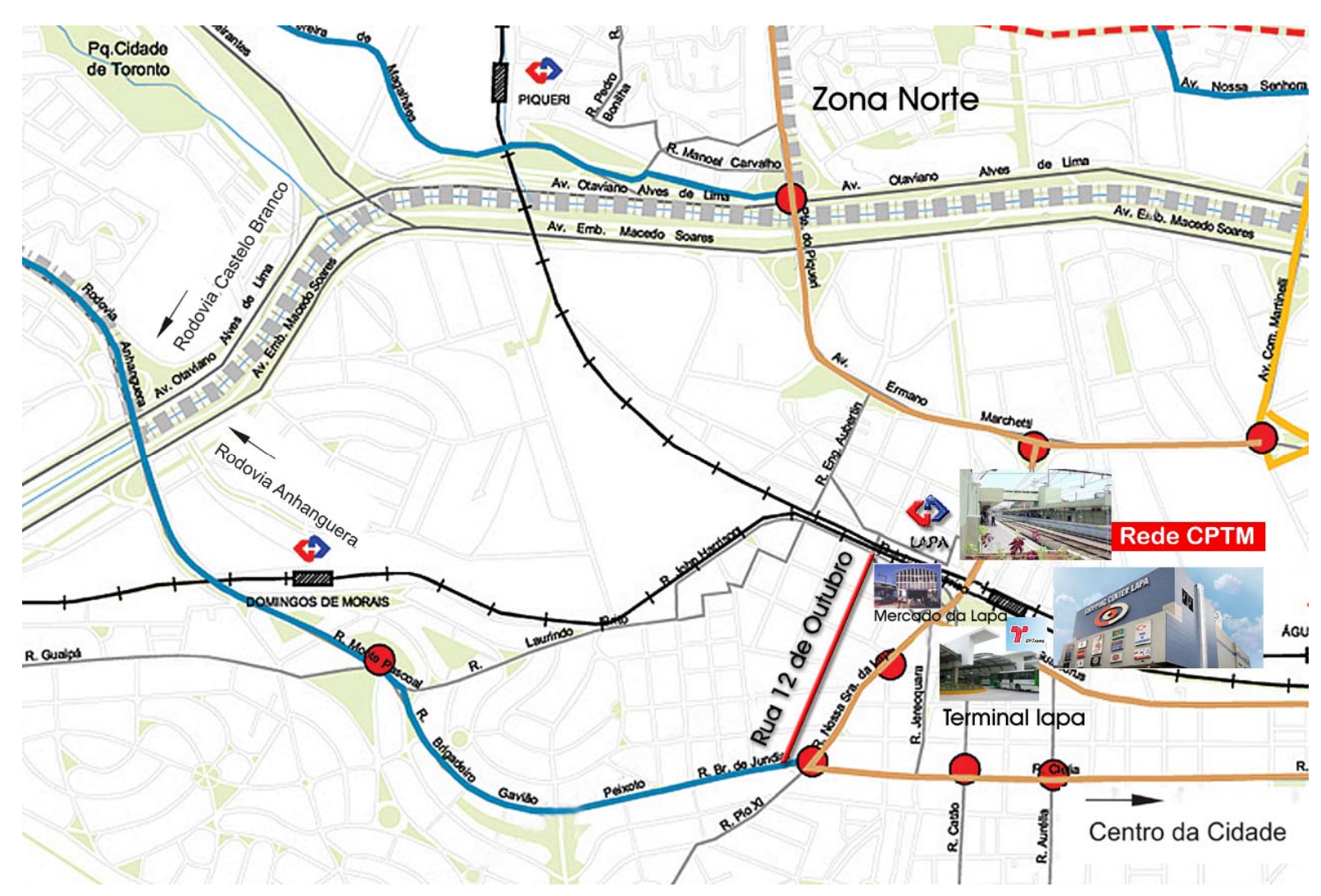

Figura 5.1 - Mapa de localização, fluxos transportes /viários da rua Doze de Outubro (sem escala). Em detalhe a estação Lapa da CPTM, o Terminal de Ônibus SPTRANS, o Mercado da Lapa e o Shopping Center Lapa. Fonte: Autora, 2006. 
Até agosto de 2005, primeira fase das pesquisas da autora no local, a rua Doze de Outubro, tinha seus dois primeiros quarteirões (entre a John Harrison e a rua Clemente Álvares) fechados ao trânsito, com todo seu leito ocupado pelo comércio de ambulantes. O restante da rua eram as calçadas, que, também, estavam totalmente tomadas pelo mesmo tipo de comércio ${ }^{77}[$ (Fotos 5.1, 5.2].

No decorrer deste trabalho, pôde-se constatar algumas transformações na Rua Doze de Outubro, como reflexo do processo de revitalização recém-iniciado. As primeiras medidas importantes tomadas pela Subprefeitura da Lapa foram a retirada de todos os ambulantes que ocupavam o leito desta parte da rua e a sua liberação ao trânsito, a partir de agosto de 2005. Depois do recadastramento de todos os ambulantes, os que estavam em condições legais de acordo com a Lei $\mathrm{N}^{\mathrm{o}} 11.039 / 1991^{78}$, foram redistribuídos nas calçadas da rua, observando a distância de $15 \mathrm{~m}$ de uma barraca para outra.

Sem entrar no mérito destas ações, o fato é que os espaços públicos, antes congestionados de ambulantes que praticamente impossibilitavam a livre circulação de pedestres e, até mesmo, a visualização das vitrines das lojas, melhoraram a partir de agosto de 2005 [(Fotos 5.3 e 5.4)].

A questão da disciplina do comércio ou prestação de serviços ambulantes certamente é um dos desafios a solucionar, no caso de virem a se efetivar os projetos de revitalização, não só da rua Doze de Outubro, como de várias outras nessa mesma condição. No momento atual, a orientação da Subprefeitura da Lapa de acordo com seu chefe de gabinete, Roberto Nappo, é considerar as diretrizes da citada Lei nº 11.039/ 1991 (informação verbal, janeiro 2006).

\footnotetext{
${ }^{77}$ Em 13/07/2005, época em que foram realizados os primeiros levantamentos da autora na região, a estimativa da Subprefeitura da Lapa era a existência de 1500 ambulantes na rua Doze de Outubro e imediações.

${ }^{78}$ LEI n ${ }^{\circ}$ 11.039, DE 23 DE AGOSTO DE 1991 (regulamentada pelo Decreto $n^{\circ}$ 42.600/02), que disciplina o exercício de comércio ou prestação de serviços ambulantes nas vias e logradouros públicos do Município de São Paulo. Pelo Art. 28 da referida lei, as distâncias entre equipamentos deverão obedecer, pelo menos, a medida de 15 (quinze) metros, dentre outras restrições.
} 

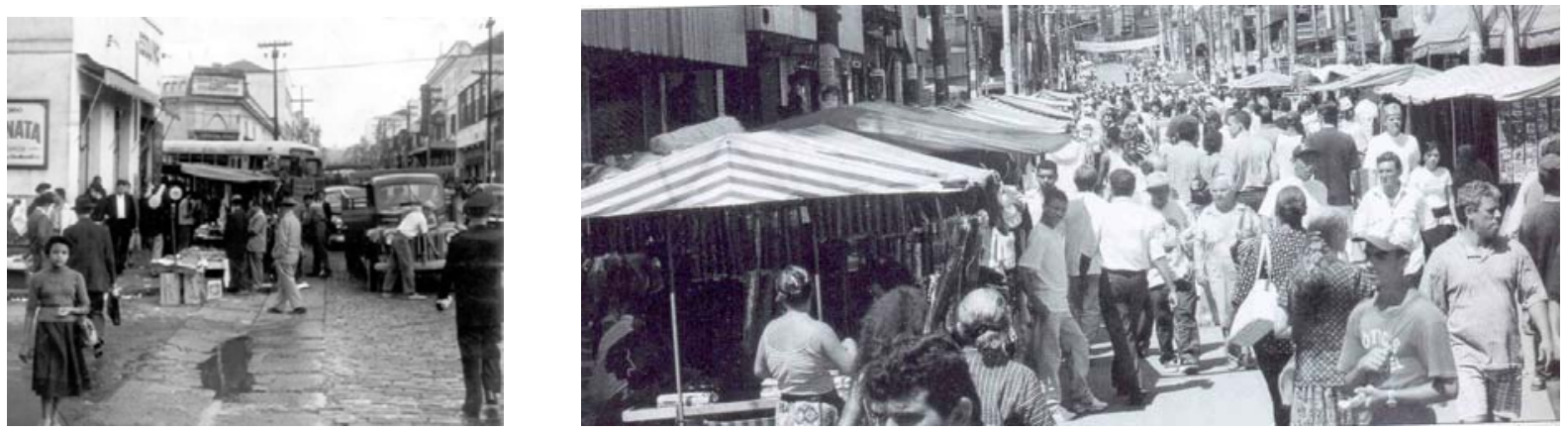

Foto 5.1: Rua Doze de Outubro em 1958

Fonte: Arquivo da Associação Comercial Distrital Lapa.

Foto 5.2: Rua Doze de Outubro, concentração do comércio ambulante, 1977.

Fonte: Arquivo da Associação Comercial Distrital Lapa.
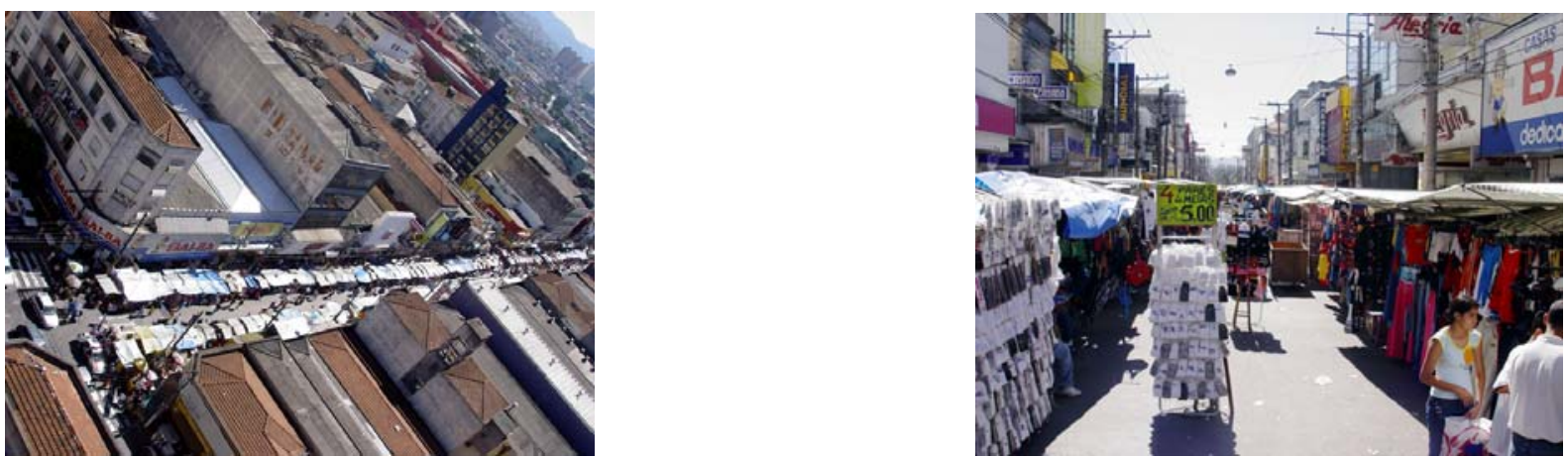

Foto 5.3: Rua Doze de Outubro, calçadas ocupada pelo comércio ambulante Fonte: Autora, Julho, 2005.

Foto 5.4: Ambulantes no leito da Rua Doze de Outubro Fonte: Autora, Julho, 2005.
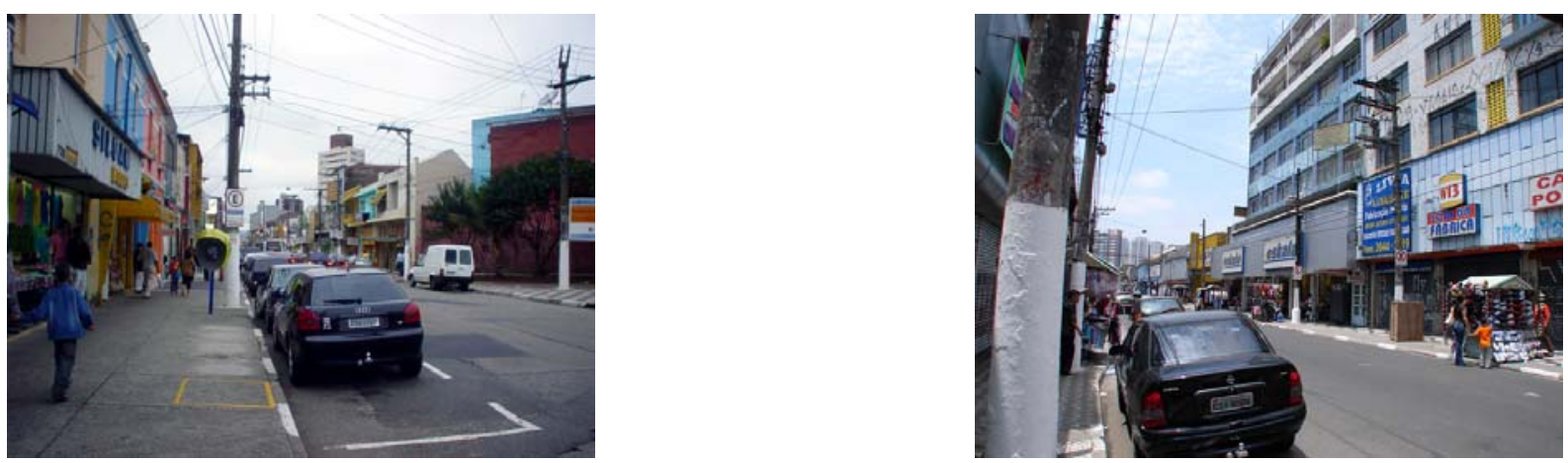

Foto 5.5: Rua Doze de outubro, depois da retirada dos ambulantes do seu leito.

Fonte: Autora, Setembro, 2005.

Foto 5.6: Rua Doze de outubro depois da retirada dos ambulantes.

Em detalhe, marcação em amarelo da localização de barraca de ambulante sobre a calçada, obedecendo a distancia de 15 metros entre uma e outra.

Fonte: Autora, Setembro, 2005. 
A configuração do comércio da rua Doze de Outubro foi obtida mediante levantamento "in loco"79, pela autora, de todas as lojas e seus respectivos endereços e atividades desenvolvidas, tendo sido localizado um total de 159 lojas.

O cruzamento das informações de campo com os dados contidas no Cadastro de Logradouro (CADLOG) e com as imagens representadas nas Plantas de Quadras da PMSP dos quarteirões que compõem a rua Doze de Outubro permitiram a consolidação do mapa do seu mix de $\operatorname{lojas}^{80}$.

Os dados das 159 lojas que formam a rua Doze de Outubro e as informações necessárias à este estudo encontram-se resumidos no ANEXO B.

\section{Segmentação do mix de lojas por atividade}

Verifica-se uma grande variedade de atividades desenvolvidas na rua Doze de Outubro (Tabela 5.1.), com predominância de Moda Feminina com 28 lojas, representado 18\% do total existente na rua, seguida por Calçados, com 17 lojas (11\%). Alimentação e Moda Infantil representam 8\% cada; Variedades, 7\%; Departamento/Magazine, 6\%; Jóias e Relógios, 5\%. Apenas uma loja desocupada (1\%). Demais atividades podem ser verificadas na Tabela 5.1. e a distribuição do mix das atividades ao longo da rua podem ser visualizadas na Figura 5.2.

\footnotetext{
${ }^{79}$ Levantamento da autora finalizado em fevereiro de 2006. Representam apenas as partes térreas sem levar em conta andares superiores, ocupadas por serviços (dentistas, escritórios de contabilidade, etc.).

${ }^{80}$ Optou-se por analisar o mix por atividade, por tipo de lojas e por tipo de produtos, sem entrar no detalhe da Área Bruta Locável (ABL), face ao objetivo deste trabalho limitação da pesquisa quanto as reais áreas ocupadas pelas loja.
} 


\begin{tabular}{|l|r|r|}
\hline \multicolumn{1}{|c|}{ ATIVIDADE } & NO. DE LOJAS & \% NO TOTAL DE LOJAS \\
\hline DEPARTAMENTO / MAGAZINE & 9 & $6 \%$ \\
MODA FEMININA & 28 & $18 \%$ \\
MODA INFANTIL & 13 & $8 \%$ \\
MODA MASCULINA & 7 & 7 \\
MODA JOVEM & 17 & $4 \%$ \\
CALÇADOS & 12 & $4 \%$ \\
ALIMENTAÇÃO & 7 & $11 \%$ \\
PERFUMARIA/COSMÉTICOS & 8 & $8 \%$ \\
JOALHERIA E RELÓGIOS & 3 & $4 \%$ \\
BIJOUTERIAS & 6 & $5 \%$ \\
LIVRARIA/ CDS & 4 & $2 \%$ \\
GALERIAS & 5 & $4 \%$ \\
DROGARIA & 11 & $3 \%$ \\
VARIEDADES & 6 & $3 \%$ \\
SERVIÇOS & 15 & $7 \%$ \\
OUTRAS ATIVIDADES & 1 & $4 \%$ \\
LOJA DESOCUPADA & 159 & $9 \%$ \\
\hline \multicolumn{1}{|c|}{ TOTAL } & & $1 \%$ \\
\hline
\end{tabular}

Tabela 5.1 - Distribuição do Mix das lojas na rua Doze de Outubro segmentação por atividades. Detalhes no Anexo B.

Lojas de Departamento de Linha Limitada incluem lojas de Eletroeletrônicos e Magazines. Lojas de Variedades, representam aquelas com grande concentração de produtos diversificados, comum em lojas de rua. Lojas de Serviços incluem Bancos, Financeiras, Planos de Saúde, Cabeleireiros. Galerias encontravam-se subdivididas em boxes. Outras atividades representam Óticas, Acessórios, Material Fotográfico, Malas e produtos afins.

Fonte: Levantamento da autora; 2006. 


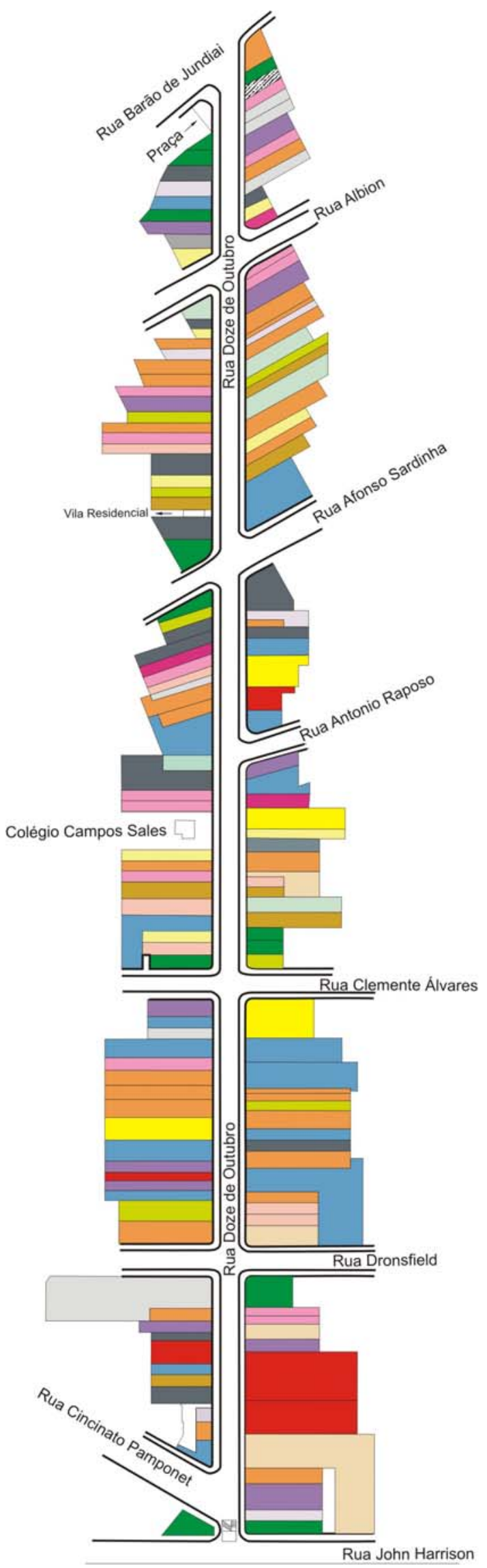

\section{LEGENDA}

Moda Feminina

$\square$ Moda Infantil

Moda Jovem

Moda Masculina

Eletrodomésticos/Eletrônicos

Calçados

Bijouterias

Galeria

Alimentação

Variedades

Outros

- Perfumaria/Cosméticos

$\square$ Jóias/Relógios

$\square$ Serviços

Livrarias/Cds

Departamento/Magazine

Drogaria

Loja Desocupada

Figura 5.2. Mapa do mix de lojas da rua Doze de Outubro, distribuição por atividades; sem escala. Fonte: Levantamento da autora; 2006. 


\section{Segmentação por tipos de Lojas}

Utilizando-se dos conceitos contidos no capitulo 1 deste trabalho, a segmentação por tipo de lojas, indica predominância de Lojas de Especialidade (modas feminina, masculina, jovem, infantil; calçados, perfumaria/cosméticos; joalherias/relógios; livrarias/CDs, inclusive, as de atividades relacionadas a venda de acessórios, material fotográfico, etc...) que totalizam 111 lojas, ou, 70\% das existentes na rua. Lojas de Alimentação representam 8\%; Lojas de Descontos, 7\%; Departamento Especializado e/ou Magazines 6\%; Lojas de Serviços, 4\%; Conveniência e Galerias, 4 \%. [Gráfico 5.1]

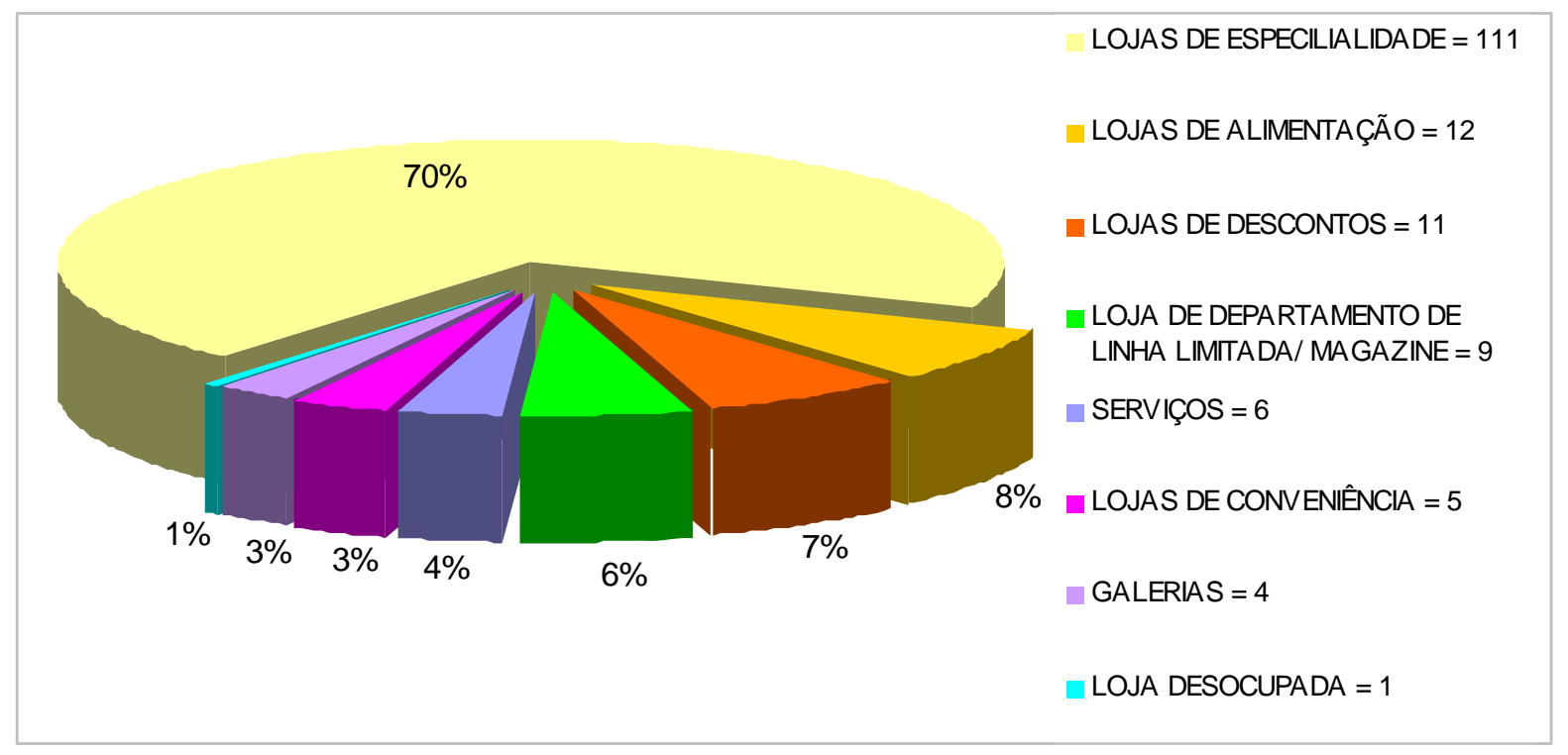

Gráfico 5.1 - Segmentação do mix por tipo de lojas existentes na rua Doze de Outubro.

Fonte: Levantamento da autora, 2006.

A distribuição dos tipos de lojas ao longo da rua Doze de Outubro pode ser melhor interpretada na Figura 5.3. 


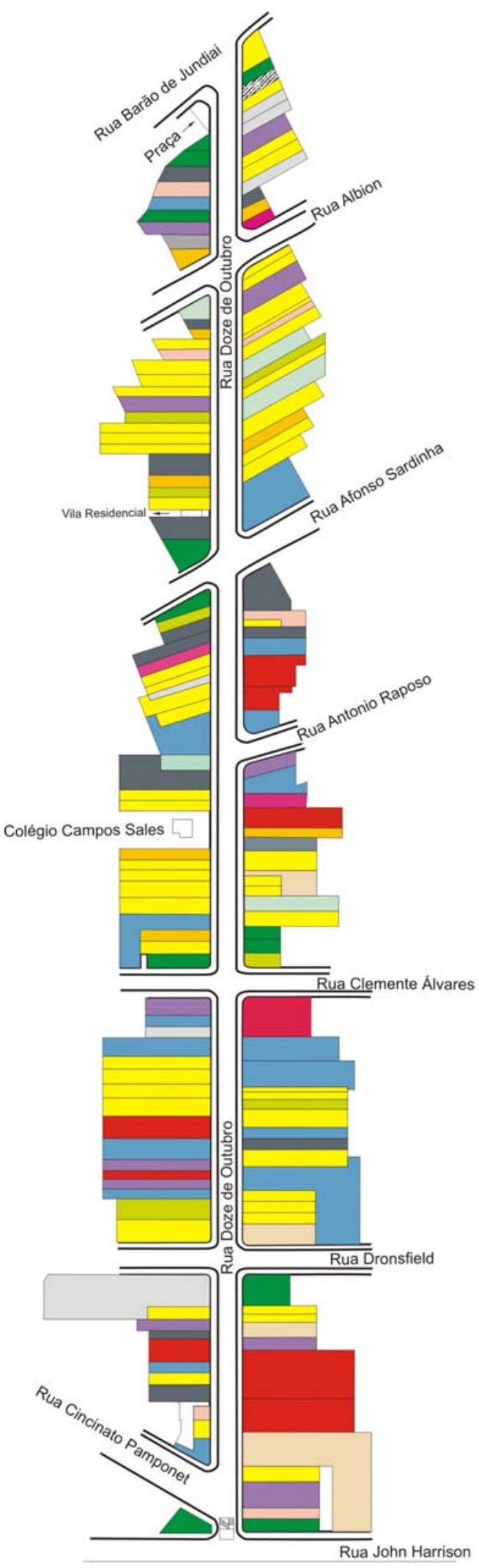

\section{LEGENDA}

Lojas Departamento Linha Limitada/Magazines Lojas Especializadas-Roupas

Lojas Especializadas-Calçados

Lojas Especializadas-Perfumaria/Cosméticos

- Lojas Especializadas-Jóias/Relógios

- Lojas Especializadas-Bijouterias

Lojas Especializadas-Livrarias/Cds

Lojas de Descontos

Lojas de Conveniência-Drogarias

Alimentação

$\square$ Serviços

Outros

$\square$ Galeria

Loja Desocupada

Figura 5.3. Mapa de dispersão dos tipos de lojas existentes na rua Doze de Outubro; sem escala Fonte: Levantamento da autora; 2006. 


\section{Segmentação por tipo de Produtos}

Na segmentação das lojas da rua Doze de Outubro por tipo de produto (Tabela 5.2), verificase a existência de 55 Lojas de Roupas, representando 35\% do total das lojas da rua;, Calçados; 11\%; Jóias/ Relógios, 5\%; Perfumes/Cosméticos e Livros e CDs; 4\%, cada; , Eletroeletrônicos, $2 \%$. Demais produtos, $42 \%$ das lojas da rua, compreendem as Lojas de Variedades, de Alimentação, de Serviços, além das Drogarias e das Galerias.

\begin{tabular}{|l|r|r|}
\hline \multicolumn{1}{|c|}{ PRODUTOS } & $\begin{array}{r}\text { NO. DE } \\
\text { LOJAS }\end{array}$ & $\begin{array}{r}\text { \% NO TOTAL } \\
\text { DE LOJAS }\end{array}$ \\
\hline ROUPAS & 55 & $35 \%$ \\
CALÇADOS & 17 & $11 \%$ \\
JOALHERIA E RELÓGIOS & 8 & $5 \%$ \\
PERFUMARIA/COSMÉTICOS & 7 & $4 \%$ \\
LIVROS/ CDS & 6 & $4 \%$ \\
ELETROELETRÔNICOS & 3 & $2 \%$ \\
BIJOUTERIAS & 3 & $2 \%$ \\
OUTROS PRODUTOS & 60 & $38 \%$ \\
\hline \multicolumn{2}{|c|}{ TOTAL } & $\mathbf{1 5 9}$ \\
\cline { 1 - 2 } & &
\end{tabular}

Tabela 5.2- Distribuição das lojas da rua Doze de Outubro por tipos de produtos Fonte: Levantamento da autora, 2005.

Uma comparação entre os resultados da tabela 5.2 e os indicadores da pesquisa de hábitos de compra, reproduzidos no quarto capítulo, segundo a qual, depois de roupas, calçados, perfumaria/cosméticos, livros ou CDs, eletroeletrônicos e jóias são os principais produtos comprados em lojas de ruas; mostra haver coerência destas circunstâncias com o mix de lojas da Rua Doze de Outubro no tocante à sua segmentação por produtos.

A Figura 5.4 ressalta apenas as lojas de roupas e calçados no mix de distribuição das lojas da rua Doze de Outubro e nela pode-se ver a dispersão das de roupas por praticamente toda extensão da rua e a maior concentração das de calçados no segundo quarteirão, especialmente entre as ruas Dronsfield e Clemente Álvares: do total das 17 Lojas de Calçados existentes na rua, 8 lojas (ou 47\%) estão concentradas neste quarteirão. 


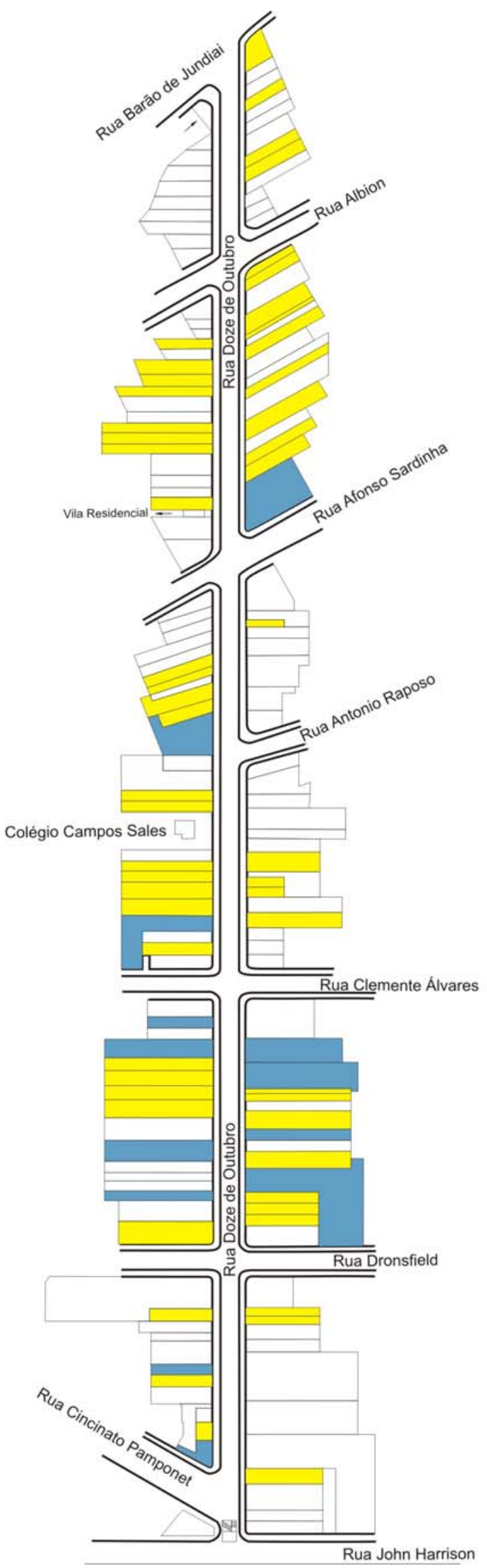

\section{LEGENDA}

Lojas Especializadas-Roupas

Lojas Especializadas-Calçados

Figura 5.4. Mapa da dispersão das lojas de roupas e calçados na rua Doze de Outubro; sem escala Fonte: Levantamento da autora; 2006. 
Verifica-se, igualmente, outras características importantes na distribuição das lojas da rua Doze de Outubro (Figura 5.5). As Lojas de Departamento de Linha Limitada e Magazines (que incluem a Lojas Americanas, as três lojas das Casas Bahia), por exemplo, ocupam os primeiros quarteirões da rua (até a rua Clemente Álvares), onde existe a maior concentração de pedestres devido à maior proximidade à estações de trens e ao terminal de ônibus, enquanto que, as Lojas Conveniência (Drogarias) estão nos últimos trechos. As Lojas de Variedades (Lojas de Descontos), por sua vez estão dispersas ao longo de toda rua Doze de Outubro,as quais, pelo tipo de produtos (mais baratos) não se beneficiam da compra comparada, ao contrário, por exemplo, do que se verifica com as lojas de calçados

Estas circunstâncias, de certa forma, retratam as colocações de Villaça (1998), do poder de atração da rua de comércio quando o seu mix de lojas alcançado pela demanda de mercado, conquista a "variedade equilibrada" na sua distribuição.

A existência de concentrações de lojas por seguimento de produtos, em determinados trechos da rua Doze de Outubro, mostradas nas figura 5.4 e 5.5. refletem uma tendência dos lojistas de se agruparem por produtos, conseguindo agregar concorrentes um do lado do outro e induzir o consumidor ao local através da "compra comparada" 81 .

\footnotetext{
${ }^{81}$ Ver capítulo 1
} 


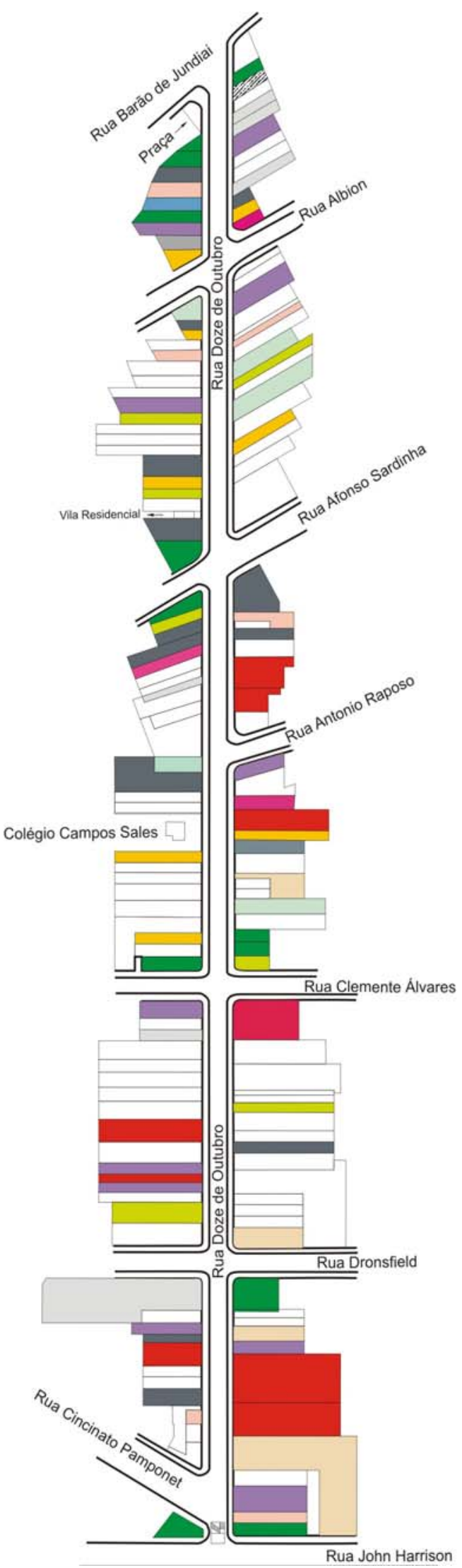

\section{LEGENDA}

Lojas Departamento Linha Limitada/Magazines Lojas Especializadas-Perfumaria/Cosméticos Lojas Especializadas-Jóias/Relógios Lojas Especializadas-Bijouterias

Lojas Especializadas-Livrarias/Cds

Lojas de Descontos

Lojas de Conveniência-Drogarias

Alimentação

Serviços

Outros

Galeria

Loja Desocupada

Figura 5.5. Mapa da dispersão das lojas por segmento de produtos na rua Doze de Outubro; sem escala Fonte: Levantamento da autora; 2006. 
Vale ressaltar, finalmente, que, estas peculiaridades verificadas na rua Doze de Outubro, têm relação com o valor de um "ponto" comercial que depende, além da acessibilidade da população residente e em deslocamento, da atração física da loja, do uso do solo do entorno, da qualidade dos produtos oferecidos, que se constituem em um conjunto de oito princípios básicos sobre localização de uma loja destacados por Richard Nelson ${ }^{82}$.

Dentre os oito princípios propostos pelo referido autor, cabem distinguir como evidentes neste particular estudo, o da "compatibilidade", que maximiza a incidência da proximidade de negócios compatíveis para aumentar o intercâmbio de consumidores e o da "atração cumulativa", ou seja, o consumidor prefere comparar diversas lojas antes de efetuar a compra, principalmente para itens preço, padrão, qualidade e moda e, consequentemente, lojas próximas, que atendem a esses requisitos, podem atrair mais negócios do que as localizadas em separado.

A inexistência de lojas de grande porte nas ruas de comércio, como se verifica na rua Doze de Outubro, dificulta instalações das chamadas lojas de departamento de linha limitada especializadas em vestuário encontradas atualmente nos shopping centers, tais como C\&A, Renner, Riachuelo e, neste caso, as lojas consideradas "lojas satélites" em shoppings focados nas classes $\mathrm{C}$ e $\mathrm{D}$, tais como Besni, Pontal além dos seu próprio mix diversificado de lojas se constituem no pólo de atração.

Não se pretende, com estas análises, atribuir o mérito da atração do consumidor à rua Doze de Outubro somente ao seu mix de lojas, porque a sua localização estratégica - no caso uma das regiões mais bem atendidas por transporte público, trem e ônibus municipais e regionais desde o início de sua formação como rua de comércio - possibilita a formação de um grande

\footnotetext{
${ }^{82}$ Detalhes dos oito requisitos (chek list) com o propósito do referido autor de analisar o ponto de localização de uma loja no capítulo 1 .
} 
fluxo de circulação e uma alta concentração de pedestres e, conseqüentemente, uma extensa área de influência.

Entretanto, a combinação especialmente desses dois fatores - variedade do mix de lojas e facilidade de acesso - permite a circulação e deslocamento fácil e maior atração do consumidor à rua de comércio. 


\section{6 - CONSIDERAÇÕES FINAIS}

O principal objetivo deste trabalho foi levantar aspectos relevantes que configuram a dinâmica da rua de comércio na cidade de São Paulo.

Analisada essa dinâmica pela evolução histórica e pela expansão territorial da cidade, viu-se o crescimento do comércio acompanhando o deslocamento da população de acordo com a renda, num processo de crescente segregação espacial. Desde sua formação, a rua de comércio acompanhou o deslocamento residencial das classes de maior renda - indo, no início do século XX, da rua Quinze de Novembro para a rua Direita, atravessando o Vale do Anhangabaú na década de 1930 e se instalando nas imediações da rua Barão de Itapetininga para, posteriormente, por volta de 1950, alcançar a rua Augusta. A rua Augusta perdeu sua atratividade, no final da década de 1960, não pelo deslocamento da população de alta renda, como ocorrera com as ruas do centro histórico, mas pelos novos hábitos de consumo introduzidos, principalmente, pelos shopping centers, no caso específico, o Iguatemi, localizado na mesma região.

O comércio da rua Augusta não conseguiu se recuperar depois da inauguração do Shopping Center Iguatemi, mas, em compensação, a rua Oscar Freire e suas imediações, tornaram-se ponto de referência das grandes grifes brasileiras e internacionais e um pólo de atração do consumidor de alta renda.

Por mais que a cidade tenha se expandido, existe, ainda, uma grande parte da população de mais alta renda concentrada nesta região (MASANO, 1993; NOBRE, 2000). O Shopping Center Iguatemi, com atualizações constantes tanto de espaço físico quanto de tenant mix, as ruas dos Jardins, simbolizada pela rua Oscar Freire, e, mais recentemente, a inauguração da Loja Daslu, formam os três principais centros comerciais desta classe social. 
As tradicionais ruas de comércio do centro histórico da cidade se popularizaram e continuam a atrair o consumidor de baixa renda, assim como, ruas ou centros comerciais de bairro, como Doze de Outubro (Zona Oeste), Teodoro Sampaio (Zona Oeste), Largo Treze (Zona Sul), Voluntários da Pátria (Zona Norte) e Maria Marcolina/Oriente/Silva Teles (Zona Leste). Isto pôde ser verificado quando analisada a dinâmica da rua de comércio pelos hábitos de compra do consumidor quando foi possível, também, analisar os principais motivos de sua atração tendo se destacado, pela ordem, o preço dos produtos (mais barato), estar passando em frente olhar e comprar (compra por impulso) e proximidade do lar (conveniência).

Com a expansão da cidade, sem planejamento urbano específico para as áreas comerciais, ruas de comércio se formam espontaneamente e crescem junto com os bairros e, devido à necessidade de atender o consumidor local, surgem as chamadas "ruas de comércio de vizinhança", nas quais é possível comprar de tudo sem depender de grandes deslocamentos, contrapondo com as "ruas especializadas" em determinados tipos de produto, a exemplo da Santa Efigênia que, com seu comércio centrado em equipamentos elétricos e eletrônicos, atrai consumidores de todas as regiões da cidade.

No cenário das transformações sociais, demográficas e econômicas do país, a conseqüência direta na atual configuração da rua de comércio foi o crescimento do consumidor das classes populares, especialmente a classe $\mathrm{C}$, que se transforma na mais disputada pelas empresas varejistas.

O aumento do consumo da população de baixa renda, viabilizada pela maior facilidade ao crédito, faz com que surjam novas ruas de comércio na cidade, assim com que mantenha a vitalidade comercial das tradicionais já existentes. Exemplos como a Casas Bahia, com um modelo de vendas focados no consumo de baixa renda através de crédito e financeiras como Itaií do Banco Itaú e Íbis da C\&A Modas, entre muitas outras, passam a se instalar 
estrategicamente nas ruas de comércio e em pontos (lojas) voltados diretamente para as calçadas.

Quando analisadas as peculiaridades de uma rua de comércio, verificadas no levantamento de campo da rua Doze de Outubro, cabem distinguir a importância do conjunto de lojas que compõem o seu tenant mix. Neste estudo foi possível constatar que o dimensionamento variado e a distribuição espacial do mix de lojas são componentes essenciais como fator de atração da rua de comércio, onde também pode ser constatada a grande importância de outro fator, o fluxo de pessoas, consumidores potenciais dos quais dependem o mercado.

A combinação desses dois fatores explica, em parte, o poder de atração e a subsistência das ruas ou centros comerciais de bairro não só da rua Doze de Outubro (Zona Oeste), como de outras ruas, que têm como característica comum o fluxo gerado pelos transportes públicos, como a Teodoro Sampaio (Zona Oeste), Largo Treze (Zona Sul) e Voluntários da Pátria (Zona Norte), guardadas as peculiaridades de cada uma delas, especialmente com relação à área de influência. O mesmo não se pode dizer, por exemplo, da rua Oscar Freire, que possui um outro contexto mercadológico, por onde o consumidor passeia, estaciona na porta das lojas e as compras estão associadas ao lazer, como passear a pé e freqüentar simultaneamente bares, restaurantes, cafés, de forma similar ao que acontece num shopping center.

A dinâmica da rua de comércio é, além de complexa, pouco estudada na sua essência e, por isso, são poucas as pesquisas específicas sobre suas constantes mutações em função da própria espacialidade urbana.

Os resultados obtidos com este estudo apontam na importância de outras pesquisas, tais como a investigação das questões urbanas estruturais e estruturantes no âmbito da rua de comércio. 
Uma questão importante, em pauta no momento, é a tendência de alteração do modelo atual de shopping center no sentido de eliminar o conceito de empreendimento em espaço fechado para uma nova concepção de espaços abertos, denominados lifestyle center - já consolidado no mercado americano e em início de implantação no Brasil - por onde o consumidor passeia, estacionando na porta das lojas, enfim, nos padrões do comércio tradicional de centros urbanos.

Caso esta tendência de empreendimentos abertos venha a se configurar na cidade de São Paulo, as conseqüências poderão ser imediatas no mercado das tradicionais ruas de comércio, situação que pode ser revertida com investimentos em segurança, lazer, enfim uma série de ações que impliquem na recuperação dos seus espaços públicos, de certa forma iniciadas com os programas de revitalização de ruas comerciais.

O desenvolvimento do comércio ocasionou importantes mudanças na cidade de São Paulo e como cada rua de comércio possui sua própria identidade determinada por particularidades como localização, área de influência, fluxo, mix de lojas, existindo um amplo leque de temas para futuras investigações, dos quais, além dos já mencionados, os possíveis cenários do varejo de rua com a inevitável consolidação do comércio eletrônico e da venda direta. 
REFERÊNCIAS BIBLIOGRÁFICAS

AB’SABER, Aziz Nacib. São Paulo Ensaios Entreveros. São Paulo: Edusp, 2004.

ABRAMO, Pedro. Mercado e ordem urbana. São Paulo: Bertrand Brasil, 2001.

ABRASCE. Associação Brasileira de Shopping Centers. Disponível em: $<$ http://www.abrasce.com.br>. Acesso em: Dezembro, 2005

ALEIXO, Cynthia Augusta Poleto. Edifícios e Galerias Comerciais em São Paulo, anos 50 e 60. Trabalho apresentado durante o I Colóquio [Inter]Nacional sobre o comércio e a cidade uma relação de origem (CINCCI). Faculdade de Arquitetura e Urbanismo da Universidade de São Paulo. Set. 2005.

ALMEIDA, Mario de. O comércio no Brasil: Iluminando a memória. Rio de Jnaeiro, Confederação do Comércio, 1995.

ALVIM, Zuleika; PEIRÃO, Solange. Mappin: setenta anos. São Paulo: Ex Libris, 1985.

AMARAL Jr, José Bento Carlos. Varejo: cresce consumo popular. EAESP-FGV. Artigo Revista Super Varejo, 2005.

ARANHA, Francisco; FIGOLI, Susana Julia. Geomarketing: Memórias de Viagem. Revista de Administração de Empresas (FGV). São Paulo. Dez. 2001.

ASSOCIAÇÃO VIVA O CENTRO. Disponível $<$ http://www.vivaocentro.org.br/bancodados/enderecos/comércio_especializado.htm>. Acesso em: Agosto, 2005

AZEVEDO, Aroldo Edgard de, coord.. A evolução urbana. In A Cidade de São Paulo: Estudos de Geografia Urbana. São Paulo: Companhia Editora Nacional, 1958.4v.

BALSAS, Carlos José Lopes. Urbanismo Comercial em Portugal e a revitalização do centro das cidades. Lisboa: Ministério da Economia, 1999.

BALSAS, Carlos José Lopes. O Urbanismo Comercial e as Parcerias Público-Privado para a Gestão do Centro das Cidades, Ensinamentos da Experiência Estrangeira. Lisboa: Sítio Observatório do Comércio, 2000. 
BROWN, Paul L. Retailing principles and practices. New York: Ronald Press Co., 1953.

BRUNA, Gilda Collet. A Problemática do Dimensionamento de Áreas Comerciais para uso no Planejamento Comercial. Tese de doutoramento. Faculdade de Arquitetura e Urbanismo da Universidade de São Paulo, 1972.

BURNS, Wilfred. British shopping centers new trends in layout and distribution. London: Hill Books Limited, 1959.

CARLOS, Ana Fani Alessandri; OLIVEIRA, Ariovaldo Umbelino de. Geografias de São Paulo. A metrópole do século XXI. São Paulo: Contexto, 2004.

CARLOS, Ana Fani Alessandri. Espaço-tempo na metrópole. São Paulo: Contexto, 2001.

CÂMARA BRASILEIRA DE COMÉRCIO ELETRÔNICO. Disponível em: http://www.camara-e.net/interna.asp Acesso em: Fevereiro, 2006.

CARTILHA DE SEGURANÇA PELA INTERNET Disponível em $<$ http://www.terra.com.br/informatica/especial/cartilha/> Acesso em Março/2006.

CASAS BAHIA. <http://www.casasbahia.com.br > Acesso em: Fevereiro, 2006.

COMIN, Álvaro. Estratégias de Desenvolvimento para a Região Central da Cidade de São Paulo. IV Relatório. Texto Síntese - Diagnósticos, Oportunidades e Diretrizes de Ação. Jul. 2003.

CORTEZ, Paulo Roberto Maia. Uma Análise das áreas de Comércio dos Shopping Centers da região metropolitana de São Paulo. Dissertação de Mestrado. Escola de Administração, Fundação Getúlio Vargas. São Paulo, 1981.

COSTA, Filipe Campelo Xavier da. Relacionamento entre influências ambientais e o comportamento de compra por impulso: um estudo em lojas físicas e virtuais. Tese de doutoramento Faculdade de Economia e Administração da Universidade de São Paulo, 2003.

DAVIDSON, William R. Retailing management. New York: Wiley, 1988.

DE ANGELO, Claudio Felisoni; e outros. Varejo: Modernização e perspectivas. São Paulo: Atlas, 1995. 
DEDECCA, Cláudio Salvatori. O trabalho na Metrópole. In História econômica da cidade de São Paulo. Vários autores. São Paulo: Globo, 2004.

EUFRÁSIO, Mario A. Estrutura urbana e ecologia urbana: a escola sociológica de Chicago. São Paulo: Ed.34, 1999.

EXCELLENCE MYSTERY SHOPPING INTERNATIONAL. Disponível em: $<$ http://www.excellencemysteryshopping.com/News_us.asp> Acesso: Janeiro, 2006.

FECOMÉRCIO [MG]. Perspectivas para o Varejo em 2005. Pesquisa. Belo Horizonte, 2004.

FRUGOLI Jr, Heitor. Os shopping-centers de São Paulo e as formas de sociabilidade no contexto urbano. Dissertação de Mestrado - Departamento de Antropologia da Faculdade de Filosofia, Letras e Ciências Humanas da Universidade de São Paulo, 1989.

GAETA, Antônio Carlos. Acumulação e transformação do espaço urbano. O processo geral de formação dos shopping centers em São Paulo. Faculdade de Filosofia, Letras e Ciências Humanas da Universidade de São Paulo, 1988.

GARREFA, Fernando. A arquitetura do comércio varejista em Ribeirão Preto: A emergência e expansão dos shopping centers. Dissertação de Mestrado. São Carlos: EESC/USP, 2002.

GASTRIOTA, Leonardo Barci. Urbanização brasileira: redescobertas. São Paulo: C/Arte, 2003.

GAZETA MERCANTIL O varejo virtual já atinge o equilíbrio. Artigo publicado em 24 de Junho de 2003. Disponível em: <http://webinsider.uol.com.br/index.php> Acesso em: junho, 2005

GIMENEZ. Luiz Carlos P.; SAAB, William George Lopes. A Segmentação do Comércio Varejista. BNDES Setorial n. 12, 2000. Disponível em: <http://www.bndes.gov.br >. Acesso em: Fev./2005.

GOLDSTUCKER, Jac. Trading Áreas. Science in Marketing, 1965 
GOMES, Henrique Ferreira; PORTUGAL, Licinio da Silva; BARROS, Julio M. A. Monteiro de. Caracterização da Indústria de Shopping Centers no Brasil. BNDES Setorial. Rio de Janeiro, n. 20. Set. 2004. Disponível em: <http://www.bndes.gov.br >. Acesso em: Mar./2005.

GOSLING, David. Design and planning of retail systems. London: Architetural Press, 1976

HOMEM, Maria Cecília Naclério. Higienópolis: grandeza e decadência de um bairro paulistano. in Centro XXI Entre História e Projeto. Prefeitura do Município de São Paulo, 1980. (Série História dos bairros de São Paulo, v.17). São Paulo: Associação Viva o Centro. São Paulo, 1994. Anais, p.4.

HUFF, David L. Deining and Estimating a Trading Área. Journal of Marketing. Jul./1964.

ICSC. International Councils of Shopping Centers. Disponível em: $<$ http://www.icsc.com $>$.

INFORMATIVO ANTEP. Comércio de Rua Qualifica-se com Áreas para Pedestres e Transporte Público. n. 93, p. 65, 02.Jul. 2002.

INSTITUTO BRASILEIRO DE PESQUISAS GEOGRÁFICAS. Disponível em < ibge.com.br. >Acesso em: Fevereiro, 2006.

INSTITUTO FLORESTAN FERNANDES. São Paulo: dinâmicas e transformações. Pesquisa CDROM. Agosto de 2000.

INSTITUTO DE PESQUISAS IBOPE Consumo; Inteligência; Mídia IBOPE/NetRatings, Internet, Investimento Publicitário. Notícias. 20/10/005. Disponível em: $<$ http://www.ebit.com.br/ebit/html/index.asp>. Acesso em: Março, 2006

JORNAL DIÁRIO DO COMÉRCIO, 23/02/06. E os brasileiros foram às compras. Disponível em http://www.dcomercio.com.br/noticias..htm.

JULIÃO, Fábio Costa. Comércio Popular e Comércio e Rua: uma Etnografia das Fronteiras entre o formal e o Informal. Trabalho apresentado durante o I Colóquio [Inter]Nacional sobre o comércio e a cidade um relação de origem (CINCCI). Faculdade de Arquitetura e Urbanismo da Universidade de São Paulo. Set./2005.

KALACHE FILHO, Jorge. Comércio varejista. Banco de Desenvolvimento Econômico e Social. Brasília: BNDES SETORIAL, 1996. 
KOTLER, Philip. Administração de Marketing: Análise, Planejamento, Implementação e Controle. São Paulo: Atlas, 1993.

Administração de Marketing: Análise, Planejamento, Implementação e Controle. São Paulo: Atlas, 5 ed., 1998.

LAS CASAS, Alexandre Luzzi. Marketing de Varejo. São Paulo: Atlas, 1997.

LEFEVRE, José Eduardo de Assis. Transporte coletivo como agente transformador da estruturação do centro da cidade de São Paulo. Dissertação de Mestrado. Faculdade de Arquitetura e Urbanismo da Universidade de São Paulo. São Paulo, 1985.

LEMOS, Carlos A. Cerqueira. Revalorização dos centros das metrópoles. São Paulo: Revista URBS, fev. 1998.

LEMOS, Mario Luiz Freitas; ROSA, Sérgio Eduardo Silveira da. O Segmento de Shopping Centers no Brasil e o BNDES. Boletim Setorial do BNDES. 2003. Disponível em: $<$ http://www.bndes.gov.br >. Acesso em: Fev./2005.

LEPSCH, Sérgio L.; TOLEDO, Geraldo Luciano. Estratégias para o Varejo. Artigo publicado no III SEMEAD - Faculdade de Economia e Administração da Universidade de São Paulo, 1998.

LIMA FILHO, Alberto de Oliveira. Shopping Centes - EUA vs BRASIL Uma Análise Comparativa. Rio de Janeiro: Fundação Getúlio Vargas, 1971.

Distribuição espacial do comércio varejista da Grande São Paulo. Instituto de Geografia da Universidade de São Paulo, 1975.

LOJAS AMERICANAS. Histórico da empresa. Disponível em: <http://ri.lasa.com.br>. Acesso em: Novembro, 2005.

LONDE, Bernard J. La. Differential in Super Market Drawing Power, Marketing and Transportation. MSU, 1962.

MASANO, Tadeu Francisco. Shopping-centers e suas relações físico-territoriais e socionegociais no município de São Paulo. Tese de doutorado apresentada à Faculdade de Arquitetura e Urbanismo da Universidade de São Paulo, 1993. 
MELLO, Margarida; GOUVEIA, Merícia; DUARTE, Teresinha. Os centros comerciais no horizonte 2010. GEPE - Gabinete de Estudos e Prospectiva Econômica do Ministério da Economia. Lisboa, 2001.

MEYER, Regina Maria Prósperi. Metrópole Urbanismo: São Paulo nos anos 50. Tese de Doutoramento. Faculdade de Arquitetura e Urbanismo da Universidade de São Paulo, 1991.

MONBEIG, Pierr et.ali. História Econômica da Cidade de São Paulo. São Paulo: Globo, 2004.

MONTEIRO, Gilson Vieira. O Futuro do Varejo de Informações na Web. Universidade do Amazonas, 1999.

MOREIRA, Antônio Cláudio M. L. Territorialidades do Comércio em São Paulo. Trabalho apresentado no I Colóquio [Inter]Nacional sobre o comércio e a cidade uma relação de origem (CINCCI). Faculdade de Arquitetura e Urbanismo da Universidade de São Paulo. Set./2005.

MORGADO, Maurício Gerbaudo; GONCALVES, Marcelo Neves. (Orgs.). Varejo: administração de empresas comerciais. São Paulo: SENAC, 1997.

NAKANO, Kazuo; CAMPOS; Candido Malta; ROLNIK Raquel. Dinâmicas dos subespaços da área central de São Paulo. Convênio Emurb/Cebrap/CEM - Estratégias de Desenvolvimento para a Região Central da Cidade de São Paulo. IV Relatório - Texto Síntese - Diagnósticos, Oportunidades e Diretrizes de Ação. Jul. 2003.

NAUFEL Felippe. Varejo de rua revigorado. Seminário GV CEV "Localização e expansão no Varejo Técnicas e Alternativas de Crescimento”, FGV-EAESP. São Paulo, agosto de 2005.

NELSON, Richard L. The selection of retail locations. New York: F.W. Dodge Corp. 1958.

NOBRE, Eduardo A.C. Reestruturação Econômica e Território: expansão recente do terciário na Marginal Pinheiros. Tese de Doutorado apresentada à Faculdade de Arquitetura e Urbanismo da Universidade de São Paulo, 2000.

O'SHAUGHNESSY, J. Why people buy. New York: Oxford University Press, cap.1, 1989. 
PAMPLONA, J. B. A atividade informal do comércio de rua e a região central de São Paulo.Caminhos para o Centro: estratégias de desenvolvimento para a região central de São Paulo. EMURB.2004.

. Erguendo-se pelos próprios cabelos: auto-emprego e reestruturação produtiva no Brasil. São Paulo: Germinal, FAPESP, 2001.

- O setor informal na região do Grande ABC paulista. Santo André: Agência de Desenvolvimento Econômico do Grande ABC, 2000. Disponível em: $<$ http://www.agenciagabc.com.br> . Acesso em outubro 2005

PARENTE, Juracy. Varejo no Brasil: Gestão e Estratégia. São Paulo: Atlas, 2000.

PARRON, Milton. São Paulo, a trajetória de uma cidade: histórioa, imagens e sons. São Paulo: Nobel, 2004.

PAZZINI, Marcos. Tendências sociais, demográficas e econômicas. Quais os vetores de expansão no Brasil? Seminário GV/CEV - Localização e expansão no Varejo Técnicas e Alternativas de Crescimento, FGV-EAESP. São Paulo, Ago./2005.

PINTAUDI, Silvana Maria. O templo da mercadoria. Estudo sobre os shopping centers do Estado de São Paulo. Tese de Doutoramento apresentada ao Departamento de Geografia da Faculdade de Filosofia, Letras e Ciências Humanas da Universidade de São Paulo, 1989.

. O shopping center no Brasil. Condições de surgimento e estratégias de localização. In PINTAUDI, S.; FRUGOLI JR., H. (Org.). Shopping centers: espaço, cultura e modernidade nas cidades brasileiras. São Paulo: Unesp, 1992.

PINTO, Dinah Sonia Renault. Shopping Center-Uma nova era empresarial. Rio de Janeiro: Forense, 1992.

PIOTTO, Rosalvo L; FÁVERO, Luiz Paulo; ANGELO, Claudio Felisoni de. O Perfil das Perdas no Varejo no BRASIL e nos EUA: Estratégias e Implicações. Artigo apresentado no VII SEMEAD - Faculdade de Economia, Administração e Contabilidade da Universidade de São Paulo, 12 ago.2005.

PLOTKIN, Manuel D. The Use Credit Accounts and Computers in Determining StoreTrading Areas. 1965. 
PONCIANO, Levino. Mil faces de São Paulo. Pequeno dicionário histórico e amoroso dos bairros de São Paulo. São Paulo: Fênix, 2000.

PORTUGAL, L. S.; GOLDNER, L. G. Estudo de pólos geradores de tráfego e de seus impactos nos sistemas viários e de transportes. São Paulo: Edgar Blücher, 2003. PRADO JR., Caio. História. São Paulo: Ática, 1982.

PSILLAKIS, Homero M. Mercado imobiliário versus varejo: um estudo de sua evolução. Artigo publicado na Revista Administração de Empresas. Rio de Janeiro: FGV, 1977.

. Shopping Center e o varejo brasileiro. Relatório de Pesquisa. São Paulo: FGV, 1984.

REIS, Nestor Goulart. São Paulo Vila Cidade Metrópole. São Paulo: Via das Artes, 2004.

REVISTA EMPREENDEDOR. Disponível em: <http://www.empreendedor.com.br $>$. Acesso em: Janeiro, 2006

REVISTA EMPORIUM. Disponível em: <http://www.emporiumsaopaulo.com.br > Acesso: Março, 2006.

ROLNIK, Raquel. A Cidade e A Lei . São Paulo: Studio Nobel, 1997.

. Reestruturação Urbana da Metrópole Paulistana: Análise de Territórios em Transição. São Paulo: Fundação de Amparo à Pesquisa do Estado de São Paulo. São Paulo, 2000.

SANTOS, Ângela Martins; COSTA, Claudia Soares; CARVALHO, Rodrigo. O Crescimento dos Shopping Centers no Brasil. São Paulo: BNDES Setorial, 1996.

SANTOS, Milton.A natureza do espaço urbano. São Paulo: Edusp, 2002.

SANTOS, Wanderley dos. História dos bairros de São Paulo. Série Histórica dos Bairros de São Paulo. v. 18. Prefeitura do Município de São Paulo: Lapa, 1980.

SÃO PAULO Prefeitura do Município de. Lei n. 11.039, de 23 de agosto de 1991. Disciplina o exercício do comércio ou prestação de serviços ambulantes nas vias e logradouros públicos do Município de São Paulo. 
SÃO PAULO Prefeitura do Município de. Decreto n. 42.600, de 11 de novembro de 2002. Regulamenta a Lei n. 11.039, que disciplina o exercício do comércio ou prestação de serviços ambulantes nas vias e logradouros públicos do Município de São Paulo. Diário Oficial do Município de São Paulo. São Paulo, 12 nov. 2002.

SÃO PAULO, Prefeitura do Município de. Secretaria Municipal de Planejamento. Plano Diretor do Município de São Paulo 1985/2000.

CORDEIRO, Helena Kohn. O centro da metrópole paulistana: expansão recente. Tese (Doutorado) - Departamento de Geografia da Faculdade de Filosofia, Letras e Ciências Humanas, Universidade de São Paulo, 1980.

SANTOS, Ângela Martins; COSTA, Cláudia Soares. Características Gerais do Varejo no Brasil. Banco de Desenvolvimento Econômico e Social. Brasília, BNDES SETORIAL, 2002.

SEBRAE-SP. Impacto da expansão das grandes redes de supermercados na atividade dos minimercados e mercearias da região metropolitana de São Paulo. PESQUISAS ECONÔMICAS. 2004.

SECRETARIA MUNICIPAL DE TRANSPORTES. Disponível em: $<$ www.stm.sp.gov.br/mapas_guias/comércio_especializado.htm>. Acesso em: Outubro, 2005

SERRA, Geraldo. O espaço natural e a forma urbana. São Paulo: Nobel, 1987.

SIMÕES, Roberto. Iniciação ao marketing. 4 ed. São Paulo: Atlas, 1986. . Dos fenícios aos hipermercados. Marketing, ano 13, n. 79, Jun. 1980.

SIQUEIRA, João Paulo Lara de. A Internet e o Varejo: uma análise dos interesses da oferta e preferência dos consumidores. Tese apresentada na Faculdade de Economia Administração e Contabilidade da Universidade de São Paulo, 2004.

SOUZA, Maria Adélia Aparecida de. A identidade da metrópole. São Paulo, Hucitec/EDUSP, 1994.

TASCHNER, Gisela B. Lazer, cultura e consumo. Artigo. Revista de Administração de Empresas. São Paulo, v. 40, n.4, p.38-47, Out. / Dez. 2000. 
TERRA, Eduardo de Almeida Salles. A classificação do Varejo: Um estudo sobre diferentes abordagens. Artigo PROVAR, 2001.

THERY, Hervé, et. ali. Retrato Cartográfico e Estatístico. In Brasil um século de Transformações. Vários autores. São Paulo: Companhia das Letras, 2001.

TOLEDO \& ASSOCIADOS. Preferência e Satisfação de Usuários de Shopping Centers de São Paulo. Pesquisas Quantitativas My Shopping. São Paulo. 2001; 2002; 2003; 2004.

TOLEDO, G. L.; BATISTA, R. N. Venda direta e varejo. In: ANGELO, C. F.; SILVEIRA, J. A. G. (Orgs.) in Varejo competitivo. São Paulo: Atlas, 1996.

ULI - Urban Land Institute. Disponível em: <http://www.uli.org>. Acesso em: Maio, 2005 VARGAS, Heliana Comim. Comércio: Localização estratégica ou Estratégia na Localização. Tese de Doutoramento. Faculdade de Arquitetura e Urbanismo da Universidade de São Paulo, 1993.

Comércio e cidade: uma relação de origem. Artigo de Jornal, 2002. Disponível em: $<$ htp://www.estadao.com.br/ext/eleições/artigos/hcomim.htm>. Acesso em: Jan./2005.

Espaço Terciário. O lugar, a arquitetura e a imagem do comércio. São Paulo: SENAC, 2001.

. Galerias no Centro. Artigo. Revista URBS. Jun. /Jul./1998.

VILLAÇA, Flávio. Espaço intra-urbano no Brasil. São Paulo: Studio Nobel: FAPESP: Lincoln Institute, 1998.

ZMITROWICZ, Witold. Funções urbano rurais como condicionantes da implantação do zoneamento na cidade de São Paulo. São Paulo, 1979. Dissertação (Mestrado) - Escola Politécnica, Universidade de São Paulo.

. As obras públicas de engenharia e a sua função na estruturação da cidade de São Paulo. São Paulo, 1985. Tese (Doutorado) - Escola Politécnica, Universidade de São Paulo.

O sonho e a realidade do Plano de Avenidas. Revista do Departamento Histórico da Secretaria Municipal da Cultura, Ano III, nº 4 . São Paulo, 1996. 
. Estruturação Urbana Conceito e Processo. Boletim Técnico Departamento de Engenharia de Construção Civil e Urbana. São Paulo, 1998.

A Estrutura da Cidade pelas Rotinas Urbanas. Tese de Livre Docência à EDUSP/PCC. São Paulo, 1997.

A conceituação de fluxo em estruturas urbanas mimeo. PCC/USP. São Paulo, 2002.

Análise de Fluxos: sua Importância na Análise e Planejamento Territorial. 2003 (texto não publicado). 
ANEXO A 


\section{INTRODUÇÃO}

PESQUISA My Shopping - 4ª edição/ 2.004 realizada anualmente desde 2001, sempre concluída no mês de Novembro pelo Instituto de Pesquisas Toledo \& Associados.

\section{FASE A - QUALITATIVA}

2.1. Para efeito de orientação dos clientes do My Shopping, foram traçadas as áreas de influência de cada Shopping Center, por meio de isocótas de 1.000, 2.000 e 3.000 metros. Estes limites não se referem às áreas de pesquisa (cluster), pois as entrevistas foram aplicadas na cidade inteira, nos seus 96 distritos.

\section{FASE B - QUANTITATIVA}

2.2. Levantar, medir e analisar, junto a 5 (cinco) amostras quantitativas, domiciliares e probabilísticas de cada região da cidade de São Paulo, das classes A, B, C e D, os seguintes dados, informações, expectativas e opiniões.

O universo desta pesquisa é o total da população paulistana das classes A-B-C-D-E, do critério ABIPEME. A classe E foi excluída desde a pesquisa de 2.001

\subsubsection{Perfil da amostra:}

- Exclusivamente freqüentadores de Shopping Centers;

- Sexo;

- Idade;

- Posse de: Casa própria; Carro próprio; Computador domiciliar; Acesso à Internet; Telefone celular; DVD; TV por assinatura;

- Classificação socioeconômica;

- Rendas pessoal e familiar.

\subsubsection{Hábitos de freqüência e compra em:}

$\checkmark$ Shopping Centers;

$\checkmark$ Lojas de Rua.

\subsubsection{Shopping Centers freqüentados e onde mais fazem compras}

\subsubsection{Ruas comerciais preferidas para compras e tipos de produtos}




\section{METODDOLOGIA}

Foi aplicado o método quantitativo, probabilístico. Isto significa que todos os domicílios das classes A, B, C e D tiveram a mesma chance de serem sorteados.

\subsection{Universo}

O universo desta amostra/ pesquisa é o total de domicílios da capital de São Paulo, das classes A, B, C, e D

\subsection{Amostra}

Quantitativa, domiciliar e probabilística.

\subsubsection{Amostral Margem de Erro}

\begin{tabular}{|l|c|c|}
\hline ZONAS & $\begin{array}{c}\text { MARGEM DE } \\
\text { ERRO }\end{array}$ & NÍVEL DE CONFIANÇA \\
\hline Norte & 4,6 & $95,0 \%$ \\
\hline Sul & 4,6 & $95,0 \%$ \\
\hline Leste & 4,6 & $95,0 \%$ \\
\hline Oeste & 4,6 & $95,0 \%$ \\
\hline Centro & 5,6 & $95,0 \%$ \\
\hline
\end{tabular}

\subsubsection{Distribuição da Amostra}

As amostras foram distribuídas nas cinco regiões da cidade, com o seguinte critério:

\begin{tabular}{|l|l|l|}
\hline ZONAS & AMOSTRA & $\%$ \\
\hline Norte & 454 & $21,4 \%$ \\
\hline Sul & 461 & $21,7 \%$ \\
\hline Leste & 453 & $21,3 \%$ \\
\hline Oeste & 451 & $21,2 \%$ \\
\hline Centro & 305 & $14,4 \%$ \\
\hline TOTAL & 2.124 & $100,0 \%$ \\
\hline
\end{tabular}


Os resultados se referem às cinco regiões da capital de São Paulo: Norte, Sul, Leste, Oeste e Centro, considerando todos os distritos e observando o percentual de classe sócio econômica da população.

\begin{tabular}{|c|c|c|c|c|c|c|c|c|} 
Zona Norte & \multicolumn{9}{c|}{ Zona Sul } \\
\hline & $\begin{array}{c}\text { Número de } \\
\text { Domicílios }\end{array}$ & $\%$ & Classes & $\begin{array}{c}\text { Número de } \\
\text { Domicílios }\end{array}$ & $\%$ & & $\begin{array}{c}\text { Número } \\
\text { de } \\
\text { Domicílios }\end{array}$ & $\%$ \\
\hline Classes & 10.175 & $2,0 \%$ & A & 40.945 & $5,0 \%$ & A & 7.860 & $0,9 \%$ \\
\hline A & 194.848 & $38,3 \%$ & B & 291.531 & $35,6 \%$ & B & 250.651 & $28,7 \%$ \\
\hline B & 229.951 & $45,2 \%$ & C & 346.398 & $42,3 \%$ & C & 458.507 & $52,5 \%$ \\
\hline C & 73.768 & $14,5 \%$ & D & 140.033 & $17,1 \%$ & D & 156.329 & $17,9 \%$ \\
\hline D & 508.742 & $100,0 \%$ & TOTAL & 818.907 & $100,0 \%$ & TOTAL & 873.347 & $100,0 \%$ \\
\hline TOTAL & & & & & & & &
\end{tabular}

\begin{tabular}{|c|c|c|c|c|c|}
\hline Zona Oeste & \multicolumn{5}{|c|}{ Centro } \\
\hline Classes & $\begin{array}{c}\text { Número de } \\
\text { Domicílios }\end{array}$ & $\%$ & Classes & $\begin{array}{c}\text { Número de } \\
\text { Domicílios }\end{array}$ & $\%$ \\
\hline A & 14.441 & $7,8 \%$ & A & 2.734 & $2,6 \%$ \\
\hline B & 77.945 & $42,1 \%$ & B & 36.172 & $34,4 \%$ \\
\hline C & 72.576 & $39,2 \%$ & C & 50.368 & $47,9 \%$ \\
\hline D & 20.180 & $10,9 \%$ & D & 15.878 & $15,1 \%$ \\
\hline TOTAL & 185.143 & $100,0 \%$ & TOTAL & $\mathbf{1 0 5 . 1 5 2}$ & $\mathbf{1 0 0 , 0 \%}$ \\
\hline
\end{tabular}

\subsubsection{Seleção da Amostra}

A amostra foi selecionada por meio de sorteios sucessivos de "clusters", quarteirões, domicílios e indivíduos no lar. Estes foram sorteados pela data de aniversário mais próxima da data de realização da entrevista.

\subsection{Técnica de Investigação}

Foram realizadas entrevistas pessoais, face-a-face, com aplicação de questionário estruturado.

\subsection{Datas de Campo}

A coleta de dados em todas as regiões da cidade ocorreu entre os dias 1 a 15 de Novembro de 2004. 
QUESTIONÁRIO - (Perguntas Referentes às Ruas)

PROJETO: "MY SHOPPING IV” - Instituto de Pesquisas Toledo \& Associados.

DATA : I I 2004 - VALIDADE : / 2005 Entrevistador:

\begin{tabular}{|l|}
\hline No do QT: \\
\hline No do Cluster: \\
\hline
\end{tabular}

Crítico:

Verificador:

Observações:

Bom dia/ Boa tarde, meu nome é sou pesquisador(a) da Toledo \& Associados e estamos realizando uma pesquisa sobre hábitos de compra. O (a) Sr. (a) poderia colaborar respondendo algumas perguntas? Obrigado (a).

P.11) Onde mais/ em que outros locais são feitas as compras de roupas para o seu uso pessoal? (ESPONTÂNEA) (RM)

\begin{tabular}{|l|c|}
\hline & (P11) PESSOAL \\
\hline Loja de rua & 1 \\
\hline Ambulante & 2 \\
\hline Sacoleira & 3 \\
\hline Shopping de atacado & 4 \\
\hline Nenhum & 5 \\
\hline Não sabe/ Não respondeu & 6 \\
\hline
\end{tabular}

P.13) (APENAS PARA QUEM RESPONDEU ALGUM ITEM NA P.12. DEMAIS, PULAR PARA P.14) Por que o(a) Sr.(a) prefere as lojas de rua para comprar estes produtos? (ESPONTÂNEA) (RM)

\begin{tabular}{|l|l|}
\hline 1 & São mais baratas \\
\hline 2 & É mais conveniente/ A gente está passando, vê o produto e compra \\
\hline 3 & É mais perto da minha casa/ Faço compras a pé \\
\hline 4 & Tenho "Conta/Crediário" nas lojas de rua \\
\hline 5 & É difícil estacionar nos Shopping Centers \\
\hline 6 & Variedade de opções de produtos \\
\hline 7 & Variedade de opções de lojas \\
\hline 8 & Mais fácil de se locomover/ não é lotado/ menos pessoas \\
\hline $\mathbf{X}$ & Outro: (ANOTE) \\
\hline
\end{tabular}

P.14) (APENAS PARA QUEM RESPONDEU CÓDIGO 1 - LOJA DE RUA - NA P.11 OU NA P.11A. DEMAIS, PULAR PARA P.15) Em quais ruas o(a) Sr.(a)/ sua família costuma fazer compras de roupas regularmente? (ESPONTÂNEA) (RM)

\begin{tabular}{|c|l|}
\hline 1 & Rua 12 de Outubro \\
\hline 2 & Rua 25 de Março \\
\hline 3 & Rua Maria Marcolina \\
\hline 4 & Rua Teodoro Sampaio \\
\hline 5 & Rua José Paulino \\
\hline 6 & Largo 13 \\
\hline 7 & Rua Direita \\
\hline 8 & Rua Voluntários da Pátria \\
\hline 9 & Rua 24 de Maio \\
\hline 10 & Rua Oriente \\
\hline 11 & Rua Barão de Itapetininga \\
\hline 12 & Rua Silva Teles \\
\hline 13 & Rua São Bento \\
\hline $\mathbf{X}$ & Outra: (ANOTE) \\
\hline
\end{tabular}


Tabela de Ruas citadas nas entrevistas (Excluindo as 12 primeiras)

\begin{tabular}{|c|c|c|c|c|c|c|c|c|c|c|}
\hline \multirow[t]{2}{*}{ Variáveis } & \multirow[t]{2}{*}{$\begin{array}{c}\text { Total } \\
\%\end{array}$} & \multicolumn{4}{|c|}{$\begin{array}{c}\text { Classe Abipeme } \\
\%\end{array}$} & \multicolumn{5}{|c|}{$\begin{array}{c}\text { Região da cidade } \\
\%\end{array}$} \\
\hline & & A & $\mathrm{B}$ & $\mathrm{C}$ & $\mathrm{D}$ & Norte & Sul & Leste & Oeste & Centro \\
\hline Base $N^{\circ}$ (Abs.) & 1876 & 57 & 652 & 865 & 302 & 421 & 398 & 392 & 395 & 270 \\
\hline Rua São Bento & 3,7 & 1,8 & 3,4 & 3,4 & 6,0 & 4,0 & 2,0 & 2,8 & 2,8 & 8,5 \\
\hline Rua da Mooca & 1,9 & - & 2,6 & 1,5 & 1,7 & 1,9 & 1,8 & 1,5 & 1,3 & 3,3 \\
\hline Av. Mateo Bei & 1,5 & - & 0,5 & 2,3 & 2,0 & - & - & 6,4 & 0,3 & 1,1 \\
\hline Rua Antonio Agu & 1,2 & - & 0,8 & 1,7 & 1,0 & 0,2 & - & - & 5,6 & - \\
\hline Calçadão de São Miguel & 1,0 & - & 0,8 & 1,3 & 1,0 & - & - & 4,8 & - & - \\
\hline Rua Silva Bueno & 1,0 & 3,5 & 1,2 & 0,9 & - & - & 4,0 & 0,5 & - & - \\
\hline Rua Augusta & 0,9 & 8,8 & 1,7 & - & - & 0,2 & 1,3 & - & 1,5 & 1,5 \\
\hline Av. Penha de Franca & 0,8 & - & 0,5 & 0,9 & 1,3 & - & - & 3,8 & - & - \\
\hline Largo da Concórdia & 0,8 & - & 0,8 & 0,8 & 1,0 & 0,2 & 1,3 & 1,8 & 0,5 & - \\
\hline Av. Sapopemba & 0,7 & - & 0,3 & 0,9 & 1,3 & - & - & 3,6 & - & - \\
\hline Rua Salvador Gianete & 0,7 & - & 0,5 & 0,8 & 1,0 & - & - & 3,1 & 0,3 & - \\
\hline Rua Domingos de Moraes & 0,7 & - & 0,9 & 0,7 & 0,3 & - & 3,3 & - & - & - \\
\hline Estrada do Campo Limpo & 0,6 & - & 1,1 & 0,6 & - & - & 3,0 & - & - & - \\
\hline Av. Jabaquara & 0,6 & - & 0,9 & 0,3 & 1,0 & - & 3,0 & - & - & - \\
\hline Rua Oscar Freire & 0,6 & 5,3 & 1,2 & - & - & 0,2 & 1,0 & - & 1,0 & 0,7 \\
\hline Rua João Cachoeira & 0,6 & 7,0 & 0,9 & 0,1 & - & - & 2,0 & - & 0,5 & 0,4 \\
\hline Rua Miller & 0,5 & - & 0,5 & 0,3 & 1,3 & 0,2 & 0,3 & 1,5 & - & 0,7 \\
\hline Rua 7 de Abril & 0,5 & - & 0,6 & 0,6 & 0,3 & 1,2 & 0,5 & - & - & 1,1 \\
\hline Rua Silvio de Campos & 0,5 & - & 0,2 & 0,7 & 0,7 & 2,1 & - & - & - & - \\
\hline Av. Lins de Vasconcelos & 0,5 & - & 0,3 & 0,5 & 1,0 & - & 0,3 & - & - & 3,0 \\
\hline Rua Floriano Peixoto & 0,5 & - & 0,3 & 0,5 & 1,0 & - & 2,3 & - & - & - \\
\hline Rua Prof. Afonso Bovero & 0,5 & 3,5 & 0,6 & 0,3 & - & - & - & - & 2,3 & - \\
\hline Largo do Japonês / Brasilândia & 0,4 & 1,8 & 0,2 & 0,5 & 0,7 & 1,7 & - & - & 0,3 & - \\
\hline Av. Teotônio Vilela & 0,4 & - & 0,8 & 0,3 & - & - & 2,0 & - & - & - \\
\hline Av. José Bonifácio & 0,4 & - & 0,2 & 0,8 & - & - & - & 0,3 & 0,5 & 1,9 \\
\hline Rua Pamplona & 0,4 & 1,8 & 0,9 & 0,1 & - & - & 1,5 & - & 0,5 & - \\
\hline Rua Bresser & 0,4 & - & 0,5 & 0,2 & 0,7 & 0,5 & 0,3 & 0,8 & 0,3 & - \\
\hline Av. Guapira & 0,4 & - & 0,5 & 0,5 & - & 1,7 & - & - & - & - \\
\hline Av. Marechal Tito & 0,4 & - & 0,2 & 0,3 & 1,0 & - & - & 1,8 & - & - \\
\hline Av. Cangaiba & 0,4 & - & 0,3 & 0,5 & 0,3 & - & 0,3 & 0,3 & 1,3 & - \\
\hline Av. Rio Branco & 0,4 & - & 0,3 & 0,6 & - & - & - & - & 1,8 & - \\
\hline Av. Tucuruvi & 0,3 & - & 0,5 & 0,3 & - & 1,2 & 0,3 & - & - & - \\
\hline Av. Celso Garcia & 0,3 & - & 0,5 & 0,3 & - & - & - & 1,0 & - & 0,7 \\
\hline Av. Itaberaba & 0,3 & - & 0,3 & 0,3 & 0,3 & 1,4 & - & - & - & - \\
\hline Rua Silvio Romero & 0,3 & - & 0,5 & 0,3 & - & 0,2 & - & 0,5 & 0,3 & 0,7 \\
\hline Av. Conselheiro Carrão & 0,3 & - & 0,5 & 0,2 & 0,3 & - & - & 1,5 & - & - \\
\hline Rua Coronel Oliveira Lima & 0,3 & - & 0,3 & 0,5 & - & - & - & 1,5 & - & - \\
\hline Av. Oratório & 0,3 & - & 0,6 & 0,2 & - & - & - & 1,5 & - & - \\
\hline Av. São Miguel & 0,3 & - & 0,2 & 0,1 & 1,3 & - & - & 1,5 & - & - \\
\hline Av. Nossa Senhora do Sabará & 0,3 & - & 0,2 & 0,5 & - & - & 1,3 & - & - & - \\
\hline Av. dos Latinos & 0,3 & - & 0,3 & 0,3 & - & - & 0,5 & 0,3 & - & 0,7 \\
\hline Avenida N.S. da Lapa & 0,3 & - & - & 0,3 & 0,7 & 1,0 & - & - & 0,3 & - \\
\hline Rua Serra Dourada & 0,3 & - & 0,2 & 0,5 & - & - & - & 1,3 & - & - \\
\hline Av. Paulista & 0,3 & 1,8 & 0,6 & - & - & - & - & - & 1,0 & 0,4 \\
\hline Av. Parada Pinto & 0,3 & - & 0,3 & 0,2 & 0,3 & 1,2 & - & - & - & - \\
\hline Rua Santa Ifigênia & 0,3 & - & 0,6 & 0,1 & - & - & - & - & 1,3 & - \\
\hline Centro do Brás (S/ especificar) & 0,5 & - & 0,6 & 0,5 & 0,3 & 1,0 & 0,3 & 1,0 & - & - \\
\hline Centro de Itaquera & 0,4 & - & - & 0,9 & - & - & - & 2,0 & - & - \\
\hline Centro da Penha & 0,3 & - & 0,3 & 0,5 & - & - & - & 1,5 & - & - \\
\hline Não lembra & 5,1 & 5,3 & 5,8 & 4,5 & 5,3 & 3,8 & 7,5 & 6,4 & 3,8 & 3,7 \\
\hline índice de multiplicidade \% & 1,9 & 2,0 & 1,8 & 1,9 & 1,8 & 1,9 & 1,7 & 1,7 & 1,9 & 2,1 \\
\hline
\end{tabular}


ANEXO B 


\section{PESQUISA DE CAMPO: RUA DOZE DE OUTUBRO, BAIRRO DA LAPA CIDADE DE SÃO PAULO}

\section{Fonte : autora}

A rua Doze de Outubro é uma típica rua comercial de bairro, formada por seis quarteirões, inicia-se na rua John Harrison, nas proximidades do Mercado da Lapa e do acesso subterrâneo à estação Lapa da Companhia Paulista de Trens Metropolitanos (CPTM) e segue até a rua Barão de Jundiaí (via intermediária de ligação da Rodovia Anhanguera e o centro da cidade)

A pesquisa de campo teve uma fase em agosto de 2005 e outra em fevereiro de 2006, durante os dias de semana, quando foi complementada e finalizada.

O processo de levantamento de campo, procedido pela autora deste trabalho, percorreu as seguintes fases:

1) levantamento de todas as lojas (partes térreas sem levar em conta andares superiores, ocupadas por serviços do tipo dentistas, escritórios de contabilidade, etc.) existentes na rua de Outubro (número da rua, frente, nome fantasia, tipo de loja);

2) nesta fase, optou-se por analisar o mix por atividade, por tipo de lojas e por tipo de produtos, sem entrar no detalhe da Área Bruta Locável (ABL), face ao objetivo deste trabalho e limitação da pesquisa quanto as reais áreas ocupadas pelas lojas;

3) cruzamento das informações de campo com os dados contidas no Cadastro de Logradouro (CADLOG) e consolidação do mapa do mix utilizando as imagens representadas nas Plantas de Quadras da PMSP dos quarteirões que compõem a rua Doze de Outubro;

4) configuração e espacialização das lojas em mapas, segmentados por atividades, por tipos de lojas e por produtos.

Os dados das 159 lojas que formam a rua Doze de Outubro e as informações necessárias à este estudo encontram-se resumidos na TABELA a seguir. 


\begin{tabular}{|c|c|c|c|c|}
\hline Ref. & $\begin{array}{l}\text { LOCAL (NO. } \\
\text { DA RUA 12) }\end{array}$ & NOME FANTASIA & ATIVIDADE & TIPO DE LOJA \\
\hline 1 & 19 & PASTELARIA CHEN & ALIMENTAÇÃO & LOJAS DE ALIMENTAÇÃO \\
\hline 2 & 24 & A ARTE DO TRIGO & ALIMENTAÇÃO & LOJAS DE ALIMENTAÇÃO \\
\hline 3 & 28 & LAPA DOS DISCOS & LIVRARIA/ CDS & LOJAS DE ESPECIALIDADE \\
\hline 4 & 32 & MINISHOPPING & VARIEDADES & LOJAS DE DESCONTOS \\
\hline 5 & 40 & MARISA & MODA FEMININA & LOJAS DE ESPECIALIDADE \\
\hline 6 & 47 & PONTO FORTE & CALÇADOS & LOJAS DE ESPECIALIDADE \\
\hline 7 & 53 & STEPHANY FASHION & MODA FEMININA & LOJAS DE ESPECIALIDADE \\
\hline 8 & 57 & MARTI SANTOS DISCOS & LIVRARIA/ CDS & LOJAS DE ESPECIALIDADE \\
\hline 9 & 58 & GALERIA CORAZA & GALERIA & GALERIA \\
\hline 10 & 66 & LOJÃO DO BRAZ & MAGAZINE & MAGAZINE \\
\hline 11 & 67 & MASKOTT ACESSÓRIOS & DIVERSOS & LOJAS DE ESPECIALIDADE \\
\hline 12 & 71 & ATANER & MODA MASCULINA & LOJAS DE ESPECIALIDADE \\
\hline 13 & 75 & DACOSTA & CALÇADOS & LOJAS DE ESPECIALIDADE \\
\hline 14 & 92 & LOJAS AMERICANAS & $\begin{array}{l}\text { DEPARTAMENTO DE } \\
\text { DESCONTOS }\end{array}$ & $\begin{array}{l}\text { LOJA DE DEPARTAMENTO } \\
\text { ESPECIALIZADA }\end{array}$ \\
\hline 15 & 105 & ESKALA & MAGAZINE & MAGAZINE \\
\hline 16 & 106 & LOJAS RENASCER & VARIEDADES & LOJAS DE DESCONTOS \\
\hline 17 & 108 & GALERIA BRANDÃO & GALERIA & GALERIA \\
\hline 18 & 109 & $\begin{array}{l}\text { COMERCIO DE } \\
\text { PLASTICOS }\end{array}$ & DIVERSOS & LOJAS DE ESPECIALIDADE \\
\hline 19 & 111 & LOJAS RENASCER & VARIEDADES & LOJAS DE DESCONTOS \\
\hline 20 & $110 / 114$ & BEBE DA LAPA & MODA INFANTIL & LOJAS DE ESPECIALIDADE \\
\hline 21 & 113 & BIA LINGERIE & MODA FEMININA & LOJAS DE ESPECIALIDADE \\
\hline 22 & 118 & LOJA BEBÊ & MODA INFANTIL & LOJAS DE ESPECIALIDADE \\
\hline 23 & 125 & BANCO BRADESCO & SERVIÇOS & SERVIÇOS \\
\hline 24 & 132 & MAC DONALD'S & ALIMENTAÇÃO & LOJAS DE ALIMENTAÇÃO \\
\hline 25 & 155 & KEEP MODAS & MODA FEMININA & LOJAS DE ESPECIALIDADE \\
\hline 26 & 158 & GALERIA SHOPPING 12 & GALERIA & GALERIA \\
\hline 27 & 161 & LAPA COSMÉTICOS & $\begin{array}{l}\text { PERFUMARIA E } \\
\text { COSMÉTICOS }\end{array}$ & LOJAS DE ESPECIALIDADE \\
\hline 28 & $164 / 68$ & START & MODA JOVEM & LOJAS DE ESPECIALIDADE \\
\hline 29 & 170 & CAMALEON & MODA JOVEM & LOJAS DE ESPECIALIDADE \\
\hline 30 & 172 & CASA DAS CALCINHAS & MODA FEMININA & LOJAS DE ESPECIALIDADE \\
\hline 31 & 173 & SHOEBIZ & CALÇADOS & LOJAS DE ESPECIALIDADE \\
\hline 32 & $176 / 178$ & MUNDIAL CALÇADOS & CALÇADOS & LOJAS DE ESPECIALIDADE \\
\hline 33 & 189 & A BARATEIRA & VARIEDADES & LOJAS DE DESCONTOS \\
\hline 34 & $190 / 198$ & SAI DE BAIXO & MODA FEMININA & LOJAS DE ESPECIALIDADE \\
\hline
\end{tabular}




\begin{tabular}{|c|c|c|c|c|}
\hline Ref. & $\begin{array}{l}\text { LOCAL (NO. } \\
\text { DA RUA 12) }\end{array}$ & NOME FANTASIA & ATIVIDADE & TIPO DE LOJA \\
\hline 35 & 191 & TAUMATEX & MAGAZINE & MAGAZINE \\
\hline 36 & 199 & LOJAS RENASCER & VARIEDADES & LOJAS DE DESCONTOS \\
\hline 37 & 202 & TAUBATÉ & DIVERSOS & LOJAS DE ESPECIALIDADE \\
\hline 38 & 205 & ALEGRIA & CALÇADOS & LOJAS DE ESPECIALIDADE \\
\hline 39 & 210 & CASADO & CALÇADOS & LOJAS DE ESPECIALIDADE \\
\hline 40 & $232 / 238$ & BESNI & CALÇADOS & LOJAS DE ESPECIALIDADE \\
\hline 41 & 215 & CASAS BAHIA & $\begin{array}{l}\text { ELETRODOMÉSTICOS E } \\
\text { ELETRONICOS }\end{array}$ & $\begin{array}{l}\text { LOJA DE DEPARTAMENTO } \\
\text { ESPECIALIZADA }\end{array}$ \\
\hline 42 & $222 / 224$ & O BOTICARIO & $\begin{array}{l}\text { PERFUMARIA E } \\
\text { COSMÉTICOS }\end{array}$ & LOJAS DE FRANQUIA \\
\hline 43 & 226 & ITEM 1 & MODA FEMININA & LOJAS DE ESPECIALIDADE \\
\hline 44 & 227 & CENTRO DE COMPRAS & MODA FEMININA & LOJAS DE ESPECIALIDADE \\
\hline 45 & 228 & MONIX & MODA FEMININA & LOJAS DE ESPECIALIDADE \\
\hline 46 & 231 & MILE MODAS & MODA FEMININA & LOJAS DE ESPECIALIDADE \\
\hline 47 & $212 / 216$ & MARISA & MODA FEMININA & LOJAS DE ESPECIALIDADE \\
\hline 48 & 237 & GRÃMOR & MODA FEMININA & LOJAS DE ESPECIALIDADE \\
\hline 49 & $242 / 246$ & GABRIELLA & CALÇADOS & LOJAS DE ESPECIALIDADE \\
\hline 50 & 245 & BEBE DO BRAS & MODA INFANTIL & LOJAS DE ESPECIALIDADE \\
\hline 51 & 255 & PONTAL & CALÇADOS & LOJAS DE ESPECIALIDADE \\
\hline 52 & 259 & IBI FINANCEIRA & SERVIÇOS & SERVIÇOS \\
\hline 53 & 260 & CASAS BAHIA & $\begin{array}{l}\text { ELETRODOMÉSTICOS E } \\
\text { ELETRONICOS }\end{array}$ & $\begin{array}{l}\text { LOJA DE DEPARTAMENTO } \\
\text { ESPECIALIZADA }\end{array}$ \\
\hline 54 & 267 & MODALL & CALÇADOS & LOJAS DE ESPECIALIDADE \\
\hline 55 & 271 & PAGUE MENOS & VARIEDADES & LOJAS DE DESCONTOS \\
\hline 56 & 291 & WAN & ALIMENTAÇÃO & LOJAS DE ALIMENTAÇÃO \\
\hline 57 & 294 & PERFUMARIA 2000 & $\begin{array}{l}\text { PERFUMARIA E } \\
\text { COSMETICOS }\end{array}$ & LOJAS DE ESPECIALIDADE \\
\hline 58 & 300 & $\begin{array}{l}\text { CASA DO PÃO DE } \\
\text { QUEIJO }\end{array}$ & ALIMENTAÇÃO & LOJAS DE ALIMENTAÇÃO \\
\hline 59 & $300 \mathrm{~A}$ & FRY CHCKEN & ALIMENTAÇÃO & LOJAS DE ALIMENTAÇÃO \\
\hline 60 & 301 & FAR - WAY & MODA JOVEM & LOJAS DE ESPECIALIDADE \\
\hline 61 & 302 & VERSATI & MODA MASCULINA & LOJAS DE ESPECIALIDADE \\
\hline 62 & 303 & CASA DAS ALIANÇAS & JÓIAS E RELÓGIOS & LOJAS DE ESPECIALIDADE \\
\hline 63 & 309 & GUTY - CALÇADOS & CALÇADOS & LOJAS DE ESPECIALIDADE \\
\hline 64 & 316 & DROGASIL & DROGARIA & LOJAS DE CONVENIÊNCIA \\
\hline 65 & 322 & INDUSTRIA DO JEANS & MODA MASCULINA & LOJAS DE ESPECIALIDADE \\
\hline 66 & 323 & GALPÃO DO SURF & MODA JOVEM & LOJAS DE ESPECIALIDADE \\
\hline 67 & 328 & ESTAÇÃO DO SURF & MODA JOVEM & LOJAS DE ESPECIALIDADE \\
\hline 68 & 329 & WYTCHER & MODA MASCULINA & LOJAS DE ESPECIALIDADE \\
\hline
\end{tabular}




\begin{tabular}{|c|c|c|c|c|}
\hline Ref. & $\begin{array}{l}\text { LOCAL (NO. } \\
\text { DA RUA 12) }\end{array}$ & NOME FANTASIA & ATIVIDADE & TIPO DE LOJA \\
\hline 69 & 332 & GALERIA DO JUCA & GALERIA & GALERIA \\
\hline 70 & 333 & BABY \& KIDS & MODA INFANTIL & LOJAS DE ESPECIALIDADE \\
\hline 71 & 337 & BAYARD & MODA FEMININA & LOJAS DE ESPECIALIDADE \\
\hline 72 & $338 / 340$ & LOJAS NANCY & MODA FEMININA & LOJAS DE ESPECIALIDADE \\
\hline 73 & $342 / 348$ & DANUBIO & DIVERSOS & LOJAS DE ESPECIALIDADE \\
\hline 74 & 345 & A SUISSA & JÓIAS E RELÓGIOS & LOJAS DE ESPECIALIDADE \\
\hline 75 & 352 & VICTÓRIA ALIANÇAS & JÓAIS E RELÓGIOS & LOJAS DE ESPECIALIDADE \\
\hline 76 & 367 & BEBE DO BRAS & MODA INFANTIL & LOJAS DE ESPECIALIDADE \\
\hline 77 & 373 & BELO BEBE & MODA INFANTIL & LOJAS DE ESPECIALIDADE \\
\hline 78 & 378 & DONNAS & BIJOUTERIAS & LOJAS DE ESPECIALIDADE \\
\hline 79 & $360 / 368$ & ESKALA & MAGAZINE & MAGAZINE \\
\hline 80 & 381 & ANTONINHO ESPORTES & DIVERSOS & LOJAS DE ESPECIALIDADE \\
\hline 81 & 382 & M\&K CALÇADOS & CALÇADOS & LOJAS DE ESPECIALIDADE \\
\hline 82 & 386 & CASA MIRANDA & VARIEDADES & LOJAS DE DESCONTOS \\
\hline 83 & 387 & $\begin{array}{l}\text { FARMACIA PAGUE } \\
\text { MENOS }\end{array}$ & DROGARIA & LOJAS DE CONVENIÊNCIA \\
\hline 84 & $401 / 405$ & MARCITA & CALÇADOS & LOJAS DE ESPECIALIDADE \\
\hline 85 & 408 & FREE LAPA & CALÇADOS & LOJAS DE ESPECIALIDADE \\
\hline 86 & 409 & CHARM LINGERIE & MODA FEMININA & LOJAS DE ESPECIALIDADE \\
\hline 87 & $414 / 422$ & MAGAZINE CLARICE & MAGAZINE & MAGAZINE \\
\hline 88 & 419 & MODAS R12 & MODA FEMININA & LOJAS DE ESPECIALIDADE \\
\hline 89 & 423 & OVERBOARD & MODA JOVEM & LOJAS DE ESPECIALIDADE \\
\hline 90 & 433 & H BABY & MODA INFANTIL & LOJAS DE ESPECIALIDADE \\
\hline 91 & 437 & JULIA CABELEREIROS & SERVIÇOS & SERVIÇOS \\
\hline 92 & 443 & VEM QUE TEM & BIJOUTERIAS & LOJAS DE ESPECIALIDADE \\
\hline 93 & 447 & MASKOTE BOLSAS & DIVERSOS & LOJAS DE ESPECIALIDADE \\
\hline 94 & 450 & CASAS BAHIA & $\begin{array}{l}\text { ELETRODOMÉSTICOS E } \\
\text { ELETRONICOS }\end{array}$ & $\begin{array}{l}\text { LOJA DE DEPARTAMENTO DE } \\
\text { LINHA LIMITADA }\end{array}$ \\
\hline 95 & 455 & NOVA OTICA & DIVERSOS & LOJAS DE ESPECIALIDADE \\
\hline 96 & 458 & FAR-WAY & CALÇADOS & LOJAS DE ESPECIALIDADE \\
\hline 97 & 465 & KINDO & $\begin{array}{l}\text { PERFUMARIA E } \\
\text { COSMETICOS }\end{array}$ & LOJAS DE ESPECIALIDADE \\
\hline 98 & 466 & POTENCIA ACESSÓRIOS & DIVERSOS & LOJAS DE ESPECIALIDADE \\
\hline 99 & 467 & HUNG SHENG & ALIMENTAÇÃO & LOJAS DE ALIMENTAÇÃO \\
\hline 100 & 470 & SEQUENCIA & MODA FEMININA & LOJAS DE ESPECIALIDADE \\
\hline 101 & 476 & GUARANI LIVRARIA & LIVRARIA/ CDS & LOJAS DE ESPECIALIDADE \\
\hline 102 & 480 & JAMIL'S TECIDOS & DIVERSOS & LOJAS DE ESPECIALIDADE \\
\hline
\end{tabular}




\begin{tabular}{|c|c|c|c|c|}
\hline Ref. & $\begin{array}{l}\text { LOCAL (NO. } \\
\text { DA RUA 12) }\end{array}$ & NOME FANTASIA & ATIVIDADE & TIPO DE LOJA \\
\hline 103 & 495 & LANCHONET & ALIMENTAÇÃO & LOJAS DE ALIMENTAÇÃO \\
\hline 104 & $501 / 509$ & TIARA BOLSAS & DIVERSOS & LOJAS DE ESPECIALIDADE \\
\hline 105 & 506 & ALEGRIA CALÇADOS & CALÇADOS & LOJAS DE ESPECIALIDADE \\
\hline 106 & 521 & WORD'S & MODA MASCULINA & LOJAS DE ESPECIALIDADE \\
\hline 107 & 523 & KINDO & $\begin{array}{l}\text { PERFUMARIA E } \\
\text { COSMÉTICOS }\end{array}$ & LOJAS DE ESPECIALIDADE \\
\hline 108 & 529 & PRATALINDA & JÓIAS E RELÓGIOS & LOJAS DE ESPECIALIDADE \\
\hline 109 & 530 & GARBO & MODA MASCULINA & LOJAS DE ESPECIALIDADE \\
\hline 110 & 536 & LAPA LINGERIE & MODA FEMININA & LOJAS DE ESPECIALIDADE \\
\hline 111 & 539 & LOJAS MARABRAS & DIVERSOS & LOJAS DE ESPECIALIDADE \\
\hline 112 & 540 & PRATALINDA & JÓAIS E RELÓGIOS & LOJAS DE ESPECIALIDADE \\
\hline 113 & 545 & MYMO'S & MODA JOVEM & LOJAS DE ESPECIALIDADE \\
\hline 114 & $546 / 552$ & DE MOURA & MODA FEMININA & LOJAS DE ESPECIALIDADE \\
\hline 115 & 549 & LOJAS GUINZA & MODA INFANTIL & LOJAS DE ESPECIALIDADE \\
\hline 116 & 553 & ATANER & MODA FEMININA & LOJAS DE ESPECIALIDADE \\
\hline 117 & 558 & DROGASIL & DROGARIA & LOJAS DE CONVENIÊNCIA \\
\hline 118 & 559 & O BOTICARIO & $\begin{array}{l}\text { PERFUMARIA E } \\
\text { COSMÉTICOS }\end{array}$ & LOJAS DE FRANQUIA \\
\hline 119 & 563 & JC COM E IMPORTAÇÃO & VARIEDADES & LOJAS DE DESCONTOS \\
\hline 120 & 568 & DIM VANELLI & MODA MASCULINA & LOJAS DE ESPECIALIDADE \\
\hline 121 & 573 & YUKARI & MODA INFANTIL & LOJAS DE ESPECIALIDADE \\
\hline 122 & 576 & CONTEM 1g & $\begin{array}{l}\text { PERFUMARIA E } \\
\text { COSMÉTICOS }\end{array}$ & LOJAS DE FRANQUIA \\
\hline 123 & 577 & SURIAN MODAS & MODA FEMININA & LOJAS DE ESPECIALIDADE \\
\hline 124 & 583 & C \& S COMPANY & MODA FEMININA & LOJAS DE ESPECIALIDADE \\
\hline 125 & 584 & DROGARIA ONOFRE & DROGARIA & LOJAS DE CONVENIÊNCIA \\
\hline 126 & 587 & ESTAÇÃO DA MUSICA & LIVRARIA/ CDS & LOJAS DE ESPECIALIDADE \\
\hline 127 & 592 & M\&R - MODAS & MODA FEMININA & LOJAS DE ESPECIALIDADE \\
\hline 128 & 597 & CHIOSCO & MODA FEMININA & LOJAS DE ESPECIALIDADE \\
\hline 129 & 598 & STYLE MUSIC STORE & LIVRARIA/ CDS & LOJAS DE ESPECIALIDADE \\
\hline 130 & 599 & RELOJOARIA EURICO & JOIAS E RELÓGIOS & LOJAS DE ESPECIALIDADE \\
\hline 131 & 600 & MILCHARME & MODA FEMININA & LOJAS DE ESPECIALIDADE \\
\hline 132 & 603 & HT COLOR & DIVERSOS & LOJAS DE ESPECIALIDADE \\
\hline 133 & 604 & PONTO A PONTO & MODA FEMININA & LOJAS DE ESPECIALIDADE \\
\hline 134 & 609 & DROGA RAIA & DROGARIA & LOJAS DE CONVENIÊNCIA \\
\hline 135 & 615 & DROGA RAIA & DROGARIA & LOJAS DE CONVENIÊNCIA \\
\hline 136 & 622 & PETIT BEBE & MODA INFANTIL & LOJAS DE ESPECIALIDADE \\
\hline
\end{tabular}




\begin{tabular}{|c|c|c|c|c|}
\hline Ref. & $\begin{array}{l}\text { LOCAL (NO. } \\
\text { DA RUA 12) }\end{array}$ & NOME FANTASIA & ATIVIDADE & TIPO DE LOJA \\
\hline 137 & 626 & BEATRIZ BABY \& KID'S & MODA INFANTIL & LOJAS DE ESPECIALIDADE \\
\hline 138 & 647 & DESTAK & JÓIAS E RELÓGIOS & LOJAS DE ESPECIALIDADE \\
\hline 139 & 650 & VEM QUE TEM & BIJOUTERIAS & LOJAS DE ESPECIALIDADE \\
\hline 140 & 651 & COLCHOES ORTOBOM & DIVERSOS & LOJAS DE ESPECIALIDADE \\
\hline 141 & 659 & REDE GALINHA MORTA & VARIEDADES & LOJAS DE DESCONTOS \\
\hline 142 & 662 & SHOW DAS ALIANÇAS & JÓIAS E RELÓGIOS & LOJAS DE ESPECIALIDADE \\
\hline 143 & 665 & DOCERELA & ALIMENTAÇÃO & LOJAS DE ALIMENTAÇÃO \\
\hline 144 & 666 & TIARABOLSAS & DIVERSOS & LOJAS DE ESPECIALIDADE \\
\hline 145 & 673 & DUNES & CALÇADOS & LOJAS DE ESPECIALIDADE \\
\hline 146 & 674 & PLENA SAÚDE & SERVIÇOS & SERVIÇOS \\
\hline 147 & 676 & SPUITY & MODA FEMININA & LOJAS DE ESPECIALIDADE \\
\hline 148 & 677 & $\begin{array}{l}\text { SUPERCAP LIBRARIA E } \\
\text { PAPELARIA }\end{array}$ & LIVRARIA/ CDS & LOJAS DE ESPECIALIDADE \\
\hline 149 & 678 & O REI DO INFANTIL & MODA INFANTIL & LOJAS DE ESPECIALIDADE \\
\hline 150 & 686 & $\begin{array}{l}\text { TANIA CRISTINA } \\
\text { IMPORTADOS }\end{array}$ & VARIEDADES & LOJAS DE DESCONTOS \\
\hline 151 & 689 & FOTO KOREA & DIVERSOS & LOJAS DE ESPECIALIDADE \\
\hline 152 & 693 & MONTHES CAFETERIA & ALIMENTAÇÃO & LOJAS DE ALIMENTAÇÃO \\
\hline 153 & 693 & CACAU CHOCOLATES & ALIMENTAÇÃO & LOJAS DE ALIMENTAÇÃO \\
\hline 154 & 696 & $\begin{array}{l}\text { ESCOLA DE } \\
\text { CABELEIREIROS }\end{array}$ & SERVIÇOS & SERVIÇOS \\
\hline 155 & 700 & BANCA PARATODOS & SERVIÇOS & SERVIÇOS \\
\hline 156 & 710 & LOJA JAPONESA & MODA INFANTIL & LOJAS DE ESPECIALIDADE \\
\hline 157 & 716 & DESOCUPADA & DESOCUPADA & DESOCUPADA \\
\hline 158 & 722 & $\begin{array}{l}\text { ARAMZÉM DOS } \\
\text { SALGADOS }\end{array}$ & ALIMENTAÇÃO & LOJAS DE ALIMENTAÇÃO \\
\hline 159 & 728 & SILOAM MODAS & MODA FEMININA & LOJAS DE ESPECIALIDADE \\
\hline
\end{tabular}

